\title{
Nepal: Poverty Reduction Strategy Paper Progress Report
}

Poverty Reduction Strategy Papers (PRSPs) are prepared by member countries in broad consultation with stakeholders and development partners, including the staffs of the World Bank and the IMF. Updated every three years with annual progress reports, they describe the country's macroeconomic, structural, and social policies in support of growth and poverty reduction, as well as associated external financing needs and major sources of financing. This country document for Nepal, dated June 2006, is being made available on the IMF website by agreement with the member country as a service to users of the IMF website.

To assist the IMF in evaluating the publication policy, reader comments are invited and may be sent by e-mail to publicationpolicy@imf.org.

Copies of this report are available to the public from

International Monetary Fund • Publication Services

$70019^{\text {th }}$ Street, N.W. • Washington, D.C. 20431

Telephone: (202) 623-7430 • Telefax: (202) 623-7201

E-mail: publications@imf.org • Internet: http://www.imf.org

Price: $\$ 18.00$ a copy

\section{International Monetary Fund \\ Washington, D.C.}





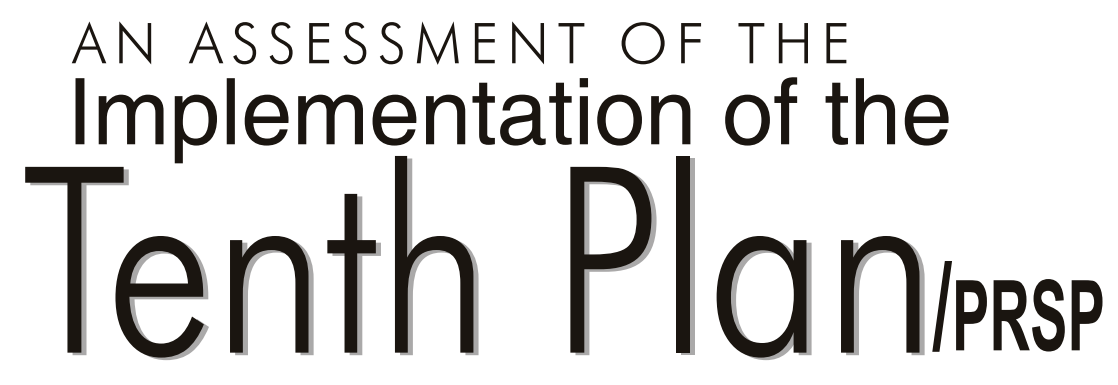

PRSP REVIEW 2004/05

G O VERN MENT O F NEPAL

NATIO NAL PLAN N IN G CO M MISSIO N SECRETARIAT Singh Durbar, Kathmandu, Nepal

June 2006 


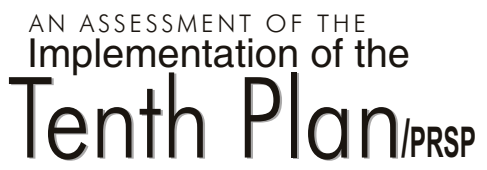

@G overnment of $\mathrm{N}$ epal, $\mathrm{N}$ ational Planning $\mathrm{C}$ ommission Secretariat Singh Durbar, K athmandu, N epal, June 2006 


\section{Foreword}

TheG overnment of $\mathrm{N}$ epal developed aPoverty M onitoringand AnalysisSystem (PMAS) in M ay 2004. The PM A S has five components, and includes inter mediateand outcome indicators. Theinfor mation on inter mediateindicators is collected from themanagement information systems at sectoral ministries and outcome indicators are obtained from household surveys conducted by the Central Bureau of Statistics (CBS). M onitoring and evaluation studies are undertaken for assessing policies, programmes and projects. Two monitoring studies, one on the Women Development Programme and another, theH ills Leasehold Forestry and F orageD evelopment Project, were conducted in 2005. Whileintermediateand outcomeindicatorsreport progress against thePoverty Reduction Strategy Paper (PRSP)targets, theimpact studiesprovideinputsin themonitoring process. Theimpact studies also help in linking intermediate and outcomeindicators while the monitoring of targeted programmesprovidefeedback on waysto improvefund transfers to service providers. All of these actions, including the participatory monitoring mechanism being developed, ar eexpected to broaden and deepen thePM A Sby helping bring the voices of peopleinto themonitoring and planning processes

The process and activities performed under the PM A S and PRSP implementation are reported through annual progress reports. Two such reportshaveal ready been published. This document reports PRSP implementation up to mid-fuly 2005 in terms of the inter mediate indicators.

Broadly, the results in the third year of the PRSP implementation are mixed. There has been improvement in some areas while progress has been slow in others owing largely to the conflict and political instability. Reforms that began in the late 1980s and continued throughout the 1990s have resulted in increases in both per capita income and consumption, and overall poverty has declined from 42 percent in 1995/ 96 to 31 percent in 2003/04. H owever, it has been increasingly difficult to sustain and build on the gains because of political instability and escalation of the conflict after 2001. Theconflict and political instability remain major obstacles to economic growth and restoring peace, and maintaining macroeconomic stability is vital for restoring investor confidence and re-starting recovery and development.

Thisprogress report will feed into themid-term review of theTenth Plan. It is believed it will also beauseful record of progress for all stakeholders and development partners interested in N epal's development efforts.

Wearegrateful to all thosewho wereinvolved in the preparation of thisreport. Sincere thanksaredueto all development partnersw ho havebeen supporting thePRSP and the government's efforts to institutionalise the PM AS. We also thank the U nited $\mathrm{N}$ ations Development Programmefor supporting the publication of this report

N ational Planning Commission Secretariat

Singha D urbar, K athmandu

June 2006 



\section{A cronyms}

\begin{tabular}{|c|c|}
\hline ADB & A sian D evelopment Bank \\
\hline ADBN & Agriculture Development Bank N epal \\
\hline ADDCN & Association of District D evelopment C ommittees of $\mathrm{N}$ epal \\
\hline AGO & Auditor General's O ffice \\
\hline AMIS & Agency M anaged Irrigation System \\
\hline ANC & A ntenatal care \\
\hline APP & Agriculture Perspective Plan \\
\hline APPSP & Agriculture Perspective Plan Support Programme \\
\hline ARI & A cuteR espiratory Infection \\
\hline ARV & Anti-retroviral Therapy \\
\hline ASY CUDA & Automated System of C ustom Data \\
\hline $\mathrm{BEOC}$ & Basic Essential O bstetric C are \\
\hline ВООТ & Build, O wn, O perate and Transfer \\
\hline CBS & Central Bureau of Statistics \\
\hline CEAPRED & $\begin{array}{l}\text { Centre for Environmental Agricultural Policy Research, Extension } \\
\text { and D evelopment }\end{array}$ \\
\hline CIAA & Commission for Investigation of Abuse of Authority \\
\hline $\mathrm{COs}$ & Community Organisations \\
\hline CSC & Citizen Score Card \\
\hline CTEVT & Council for Technical Education and Vocational Training \\
\hline CWSSP & Community-based Water Supply and Sanitation Project \\
\hline DADF & District Agricultural D evelopment Fund \\
\hline DDC & District D evelopment Committee \\
\hline DFID & D epartment for International D evelopment \\
\hline $\mathrm{DHO}$ & District $H$ ealth $O$ ffice \\
\hline DOTS & Directly O bserved Treatment Short Course \\
\hline DPP & District Periodic Plan \\
\hline DTOs & District Technical O ffices \\
\hline DWDO & District Women D evelopment O ffice \\
\hline DWSS & D epartment of Water Supply and Sewerage \\
\hline FCGO & Financial Comptroller Generd's O ffice \\
\hline FMIS & Farmer M anaged Irrigation System \\
\hline FUG & Forest U sers' Group \\
\hline FY & Fiscal Year \\
\hline GBBs & Grameen Bikas Banks \\
\hline GDP & Gross D omestic Product \\
\hline GPI & Gender Parity Index \\
\hline
\end{tabular}




\begin{tabular}{|c|c|}
\hline $\mathrm{HC}$ & $\mathrm{H}$ ealth Centre \\
\hline HDR & H uman D evelopment Report \\
\hline HLFFDP & H ills L easehold Forestry and Forage D evelopment Project \\
\hline GON & Government of $N$ epal \\
\hline HP & H ealth Post \\
\hline IDP & Internally Displaced People \\
\hline ILO & International Labour O rganization \\
\hline $\mid \mathrm{MCl}$ & Integrated M anagement of C hildhood IIIness \\
\hline IMF & International M onetary Fund \\
\hline I/NGOs & International/ N ational N on-G overnment O rganisations \\
\hline LBs & Local Bodies \\
\hline LBFC & Local Bodies Financial Commission \\
\hline LIF & Local Initiatives Fund \\
\hline LSGA & Local Self-G overnance Act \\
\hline$M \& E$ & Monitoring and Evaluation \\
\hline MDGs & Millennium D evelopment G oals \\
\hline MFIs & M icro Finance Institutions \\
\hline MIS & Management Information System \\
\hline MLD & Ministry of Local D evelopment \\
\hline MOAC & Ministry of Agricultureand Cooperatives \\
\hline MOES & Ministry of Education and Sports \\
\hline MOF & Ministry of Finance \\
\hline MOGA & Ministry of $\mathrm{G}$ eneral $\mathrm{A}$ dministration \\
\hline MOHP & Ministry of $\mathrm{H}$ ealth and Population \\
\hline MTEF & Medium Term Expenditure F ramework \\
\hline MWCSW & Ministry of Women, Children and Social Welfare \\
\hline NDA & N et D omestic A ssets \\
\hline NDDUDC & Neglected, D eprived and DalitsU pliftment D evelopment Committee \\
\hline NDHS & Nepal D emographic and H ealth Survey \\
\hline NER & $N$ et Enrolment Rate \\
\hline N LSS & N epal Living Standards Survey \\
\hline NPA & N on Performing A ssets \\
\hline NPC & $\mathrm{N}$ ational Planning Commission \\
\hline NRB & Nepal R astra Bank \\
\hline NTIP & N ew Technology Irrigation Programme \\
\hline NVC & $N$ ational Vigilance Centre \\
\hline N WSSSP & National Water Supply and Sanitation Sector Policy \\
\hline ORS & Oral Rehydration Solution \\
\hline PAC & Public A ccounts Committee \\
\hline PAF & Poverty A lleviation Fund \\
\hline
\end{tabular}




\begin{tabular}{|c|c|}
\hline PAN & Permanent A ccount $\mathrm{N}$ umber \\
\hline PMAS & Poverty M onitoring and A nal ysis System \\
\hline PMTCT & Prevention of Mother to $C$ hild Transmission \\
\hline PNC & Post-natal Care \\
\hline PPA & Participatory Poverty A ssessment \\
\hline PPM & Participatory Poverty M onitoring \\
\hline PRGF & Poverty Reduction and Growth F acility \\
\hline PRS & Poverty Reduction Strategy \\
\hline PRSC & Poverty Reduction Support Credit \\
\hline PRSP & Poverty Reduction Strategy Paper \\
\hline PSC & Public Service Commission \\
\hline RAP & Rural A ccess Programme \\
\hline RBM & Result Based M anagement \\
\hline RCCC & Royal Commission for Corruption Control \\
\hline RCIW & Rural Construction and Infrastructure Works \\
\hline RMDC & Rural Micro Finance D evelopment Centre \\
\hline RWSS & Rural Water Supply and Sanitation \\
\hline RWSSFDB & Rural Water Supply and Sanitation Fund D evelopment Board \\
\hline SAFTA & South A sian Free Trade Arrangements \\
\hline SAPPROS & Support Activities for Poor Producers of $\mathrm{N}$ epal \\
\hline SFDP & Small Farmer D evelopment Programme \\
\hline SHP & Sub-H ealth Post \\
\hline SIMI & Small Irrigation and M arketing Initiatives \\
\hline SMCs & School M anagement Committees \\
\hline STWSSSP & Small Towns Water Supply and Sanitation Sector Project \\
\hline TDF & Town D evelopment Fund \\
\hline TEGUPD & Tribal and Ethnic Groups U pliftment and Praja D evelopment \\
\hline VAT & Value Added Tax \\
\hline VDC & Village D evelopment Committee \\
\hline WB & World Bank \\
\hline WSUC & Water and Sanitation U sers' Committee \\
\hline WTO & World Trade O rganisation \\
\hline WTSS & Women Technical Support Service \\
\hline WUA & Water U sers A ssociation \\
\hline
\end{tabular}





\section{Table of Contents}

ACRONYMS
FOREWORD

Section I: INTRODUCTION

Background 1

Organisation of thereport 1

Section II: KEY NATION AL OBJECTIVESAND STRATEGIES

Overview 3

Poverty profile 4

$\begin{array}{ll}\text { The Tenth Plan/PRSP } & 7\end{array}$

Millennium development goals $\quad 8$

Section III: MACROECON OMIC PERFORMAN CE AND CHALLENGES 11

Sustaining macroeconomic stability 11

New initiatives in economic management $\quad 16$

Section IV: PUBLIC EXPENDITURE MAN AGEMENT 19

Overview $\quad 19$

$\begin{array}{ll}\text { MTEF and fiscal performance } & 19\end{array}$

Section V: BROAD-BASED GROWTH PERFORMANCE

Agriculture 25

Irrigation 27

$\begin{array}{ll}\text { Rural infrastructure } & 29\end{array}$

Power 30

Forestry 30

Promoting non-agricultural growth 33

Public enterprises refor m and privatisation 33

Financial sector reform $\quad 34$

Section VI: SO CIAL SECTOR

Education $\quad 37$

Health 44

$\begin{array}{ll}\text { Water supply and sanitation } & 49\end{array}$

Section VII: SO CIAL IN CLUSION AND TARGETED PROGRAMMES

Overview 55

Structural change and mainstreaming the excluded groups 55

Targeted programmes 56

Funding for targeted programmes $\quad 62$ 
Section VIII: GOVERN ANCE 63

Overview $\quad 63$

Civil service reform $\quad 63$

Decentralisation 65

$\begin{array}{ll}\text { Corruption control } & 67\end{array}$

$\begin{array}{ll}\text { Judicial sector reforms } & 68\end{array}$

Section IX: CONFLICT AND DEVELOPMENT 71

$\begin{array}{ll}\text { Overview } & 71\end{array}$

$\begin{array}{ll}\text { Community participation } & 74\end{array}$

Section X: POVERTY REDUCTION STRATEGY (PRS) MO N ITORING 77

Overview

Poverty M onitoring and Analysis System (PM AS) 78

$\begin{array}{ll}\text { Participatory monitoring } & 79\end{array}$

Poverty Management Information System (PMIS) 79

District Poverty M onitoring and A nalysis System (DPM AS) 80

Results-based Management and M onitoring $\quad 81$

Section XI: RESOURCE NEEDS AND AID HARMONISATION 83

Section XII: CONCLUSIONS

$\begin{array}{lr}\text { REFERENCES } & 87\end{array}$

$\begin{array}{lr}\text { ANNEXES } & 91\end{array}$ 


\section{LIST OF TABLES}

2.1 Poverty in N epal 4

2.2 Poverty by geographical region 5

2.3 Selected comparative indicators of N LSS I and N LSS II 6

2.4 Millennium Development G oals 2005-2015 10

3.1 Perfor mance of macroeconomic indicators in current prices (2001/02-2005/06) 13

3.2 Percentage growth of macroeconomic indicators (2002/03-2005/ 06) 15

4.1 Government operation (\% of GDP) 20

4.2 Inter-sectoral allocation (\% of GDP) 21

4.3 Sectoral pro-poor expenditure as percentage of total expenditure 22

5.1 Major achievements in the food and agriculture 27

5.2 Major achievements in the forestry 31

6.1 Major achievements in education $\quad 40$

6.2 Budgetary performance of the education sector 40

6.3 Major achievementsin health 46

6.4 Management transfer of health facilities 48

6.5 Budgetary analysis of health sector 49

6.6 Major achievements in drinking water and sanitation $\quad 50$

6.7 Budgetary analysis of thewater supply and sanitation sector 52

7.1 Thetargeted programmes 62

8.1 Selected civil service reform indicators 64

8.2 Selected MLD programmes on decentralisation 66

8.3 CIAA activities and outcomes 68

9.1 Growth of micro-hydro electricity generation 73

11.1 Summary of incomeand expenditure 83

LIST OF BOXES

1 Distinct features of the Tenth Plan/PRSP 1

2 N LSS results 4

3 Thefour PRSP pillars 8

4 Basic features of MTEF IV 24

5 Environmental and economic impact of leasehold forestry 32

6 Private sector development initiatives 33

7 Somemilestones in financial sector reforms 36

8 The poverty alleviation fund $\quad 57$

$9 \quad$ Strategic plan of thejudiciary (2004-2008) 69

10 K ara Irrigation Project, D ang 74

11 Community transforms hospital $\quad 75$

12 Diversification of health services $\quad 76$

13 Thepeoplespeak $\quad 80$

LIST OF FIGURES

4.1 Community and local bodies 23

5.1 N et profit of NBL and RBB 34

5.2 Proportion of NPA of NBL and RBB 35

9.1 Percentage of Ethnic G roups in total six districts population and in total PAF beneficiaries 



\section{Introduction}

\section{BACKGROUND}

$N$ epal began implementing the Poverty Reduction Strategy Paper (PRSP) in fiscal year 2002/ 03 (mid-July to mid-July). The PRSP is also N epal's Tenth Plan. It has clear poverty reduction goals and measurable socio-economic targets, which it seeks to achieve by focusing development efforts on four strategic pillars (Box 3). This report assesses progress in the third year of PRSP/T enth Plan (2004/ 05) and will also feed into the on-going mid-term review of the Plan. The government first reported on PRSP implementation for 2002/ 03 during theN epal D evelopment Forum (N DF) in M ay 2004. The report for 2003/ 04 was published in June 2005.

\section{ORGANISATION OF THE REPORT}

Thisreport has 12 sections, beginning with abroad review of poverty. Sections I and II discuss the key elements of the poverty reduction strategy, the status of the Millennium Development Goals (MDGs) and thelinks of the MDGs with the Tenth Plan. The section is followed by a review of the performance of the economy.

\section{Box 1: Distinct features of the Tenth Plan/PRSP}

- The Tenth Plan is N epal's Poverty R eduction Strategy Paper.

- ThePlan aimsat reducing poverty and enhancing human wellbeing, and contributes towards attaining the M illennium D evelopment G oals (M D Gs).

- ThePlan recognises the role of local bodies, Community O rganisations (CO s) and $\mathrm{N}$ on-G overnment O rganisations (N GO s) in development.

- ThePlan is committed to decentralisation and functional devolution.

- ThePlan usesmodern planning tools to defineinstitutional tasksand responsibilities.

- ThePlan prioritises development programmes/ projects (P1, P2 and P3), which are guaranteed resources; the outcomes are monitored consistently, and

- ThePlan haselaborateM \&E provisionsincludingannual poverty monitoring, process monitoring and reporting. 
Section IV highlights the government's efforts to realign public expenditure management to support the PRSP goals. Section V examines the progress by major sectors and also the initiatives taken by the government to improve performance. Section VI and VII review social sector performance and achievementsin social inclusion and targeted programmes. Section VIII reports progress in institutional reforms and governance and Section IX deals with the strategies and policies adopted for responding to the conflict. A $n$ analysis of themechanism to track progress is presented in Section X, which isfollowed by a discussion of resourceneeds and aid harmonisation (Section XI). Section XII summarises the report's conclusions. 


\section{Key National Objectives and Strategies}

\section{Overview}

$N$ epal began implementing thePRSP in 2002/ 03, a period marked by political instability and an escalation of violent conflict. Thereweresomeimprovements in the security situation in the later half of 2005 but the political situation had become more complex. The political environment had a direct impact on both policy reforms and development spending. The end of the tenure of elected local representatives in mid-2002 - and the inability to elect new representatives - resulted in a slowdown of development activities affecting theal readyw eak servicedelivery. Both tourist ar rival sand receipts from tourism remained low in 2005. Developments in the external front caused sharp reductions in export of $\mathrm{N}$ epal's main products - readymade garments and carpets - and the pass through of the increase in global oil prices caused consumer prices to rise. Therefore, preventing the economy from slowing down further, and sustaining thegainsattained, remained the main challenges in 2005.

The conflict and political instability havehad a lasting impact on development. Some of the direct impacts of the conflict have been:

- Destruction/ damage of development infrastructures

- Low private investment

- Slowdown in development expenditure

- Weakening grassroots service delivery

- Disruption of production, trade and transactions

- Obstruction of operation of I/ N GO s and development partners, and

- Increased migration to, and higher demand for services, in urban and semi-urban areas.

The political uncertainty compounded the development challenge and prevented thegovernment from taking thebold measures needed for enhancing economic activities. 


\section{POVERTY PROFILE}

Thegovernment published the second N epal LivingStandardsSurvey (N LSS) 2003/ 04 in early 2005. Theresults show encouragingimprovementsin accessto basic social and economic services (Box-2) and in the living standards of people (Table 2.3). O verall, the incidence of poverty has declined by 11 percentagepoints between 1995/ 96 and 2003/ 04, a decline by 3.7 percent each year. In 2003/ 04, 31 percent of the population lived in poverty compared to 42 percent in 1995/ 96.

The Poverty Line is a benchmark or a yardstick for defining who is poor and who is not. In N epal, the Poverty Line is derived by using "Cost of Basic $\mathrm{N}$ eeds" method where nutrition of 2,124 kcal per day per capita istaken as the minimum caloric requirement for an "average" N epali household. The non-food consumption value is determined using the "U pper Poverty Line Method".

\section{Box 2: NLSS results}

Percent of H ouseholds Reporting Lessthan A dequate N LSS-I N LSS-II

Food consumption $\quad 50.9 \quad 31.2$

Housing $\quad 64.1 \quad 40.6$

Clothing $\quad 57.6 \quad 35.6$

H ealth Care $\quad 58.7 \quad 28.3$

Schooling $\quad 45.4 \quad 21.4$

Total Income $\quad 72.6 \quad 67.0$

Adult literacy, Total $35.6 \quad-48.0$

Male $\quad 53.5 \quad 64.5$

Female $19.4 \quad 33.8$

$N$ et Enrolment in Primary

school Female $\quad 46.0 \quad 66.9$

Children fully immunized $36.0 \quad 59.4$

A ccess to electricity $\quad 14.1 \quad 37.2$

A ccess to piped water $\quad 32.8 \quad 43.9$

A ccess to toilet facility $21.6 \quad 38.7$

H ousehold access to facility within 30 minutes

Primary school $\quad 88.4 \quad 91.4$

H ealth post/ H ospital $\quad 44.8 \quad 61.8$

$\begin{array}{lll}\text { Agriculture centre } \quad 24.5 & 31.9\end{array}$

Commercial Banks $\quad 20.7 \quad 27.8$

Paved road $\quad 24.2 \quad 37.2$

Motorable road $\quad 58.0 \quad 67.6$

Source CBS, 1996 and 2004

\section{Table 2.1: Poverty in Nepal}

\begin{tabular}{|lrrrrrrrrr}
\hline & \multicolumn{3}{c}{ H ead count rate (P0) } & \multicolumn{3}{c|}{ Poverty gap (P1) } & \multicolumn{4}{c|}{ Squared poverty gap (P2) } \\
& $1995 / 96$ & $2003 / 04$ & Change\% & $1995 / 96$ & $2003 / 04$ & Change\% & $1995 / 96$ & $2003 / 04$ & Change\% \\
N epal & 41.76 & 30.85 & -26 & 11.75 & 7.55 & -36 & 4.67 & 2.7 & -42 \\
(Standard error) & $(1.09)$ & $(0.93)$ & & $(0.4)$ & $(0.3)$ & & $(0.21)$ & $(0.14)$ & \\
U rban & 21.55 & 9.55 & -56 & 6.54 & 2.18 & -67 & 2.65 & 0.71 & -73 \\
(Standard error) & $(2.87)$ & $(1.13)$ & & $(1.02)$ & $(0.32)$ & & $(0.51)$ & $(0.13)$ & \\
Rural & 43.27 & 34.62 & -20 & 12.14 & 8.50 & -30 & 4.83 & 3.05 & -37 \\
(Standard error) & $(1.15)$ & $(1.06)$ & & $(0.43)$ & $(0.35)$ & & $(0.23)$ & $(0.17)$ & \\
\hline
\end{tabular}

Source CBS, 2005a

Poverty incidence in urban areas declined by more than half (from $22 \%$ in $1995 / 96$ to $10 \%$ in 2003/ 04) - by almost seven percent eachyear. Thedecrease 
in rural poverty was modest; it declined from 43 percent in 1995/ 96 to about 35 percent in $2003 / 04$, or by 2.5 percent each year during eight years betw een the surveys. Rural poverty, ther efore, remains a major challenge.

The depth and severity of poverty, measured by poverty gap and squared poverty gap in Table 2.1, have al so decreased. But the decrease was higher in urban areas compared to rural areas.

N LSS II shows that except for the rural Eastern Hills (where poverty has actually increased), poverty has declined in all geographical regions. For example, poverty in the Western, $M$ idand Far-western regions declined by 30,25 and 36 percent, respectively. Still, therearemorepeopleunder the poverty line in the Midand Far-western regions compared to other regions (T able 2.2). By ecological belts, poverty has declined more rapidly in the Mountain and Tarai regions compared to the Hills: the decrease was five percent

\begin{tabular}{|c|c|c|c|}
\hline \multirow{2}{*}{$\begin{array}{l}\text { Geographic Region } \\
\text { Sector }\end{array}$} & \multicolumn{3}{|c|}{ Poverty head count rate (\%) } \\
\hline & $1995 / 96$ & $2003 / 04$ & $\%$ Change \\
\hline Urban & 21.6 & 9.6 & -56 \\
\hline Rural & 43.3 & 34.6 & -20 \\
\hline \multicolumn{4}{|l|}{ N LSS regions } \\
\hline $\mathrm{K}$ athmandu & 4.3 & 3.3 & -23 \\
\hline Other urban & 31.6 & 13.0 & -59 \\
\hline Rural Western Hill & 55.0 & 37.4 & -32 \\
\hline Rural Eastern Hill & 36.1 & 42.9 & 19 \\
\hline Rural Western Tara & 46.1 & 38.1 & -17 \\
\hline Rural Eastern Tarai & 37.2 & 24.9 & -33 \\
\hline \multicolumn{4}{|l|}{ D evel opment region } \\
\hline Eastern & 38.9 & 29.3 & -25 \\
\hline Central & 32.5 & 27.1 & -17 \\
\hline Western & 38.6 & 27.1 & -30 \\
\hline M id-Western & 59.9 & 44.8 & -25 \\
\hline Far western & 63.9 & 41.0 & -36 \\
\hline \multicolumn{4}{|l|}{ Ecological belt } \\
\hline Mountain & 57.0 & 32.6 & -43 \\
\hline Hill & 40.7 & 34.5 & -15 \\
\hline Tarai & 40.3 & 27.6 & -32 \\
\hline N epal & 41.8 & 30.8 & -26 \\
\hline
\end{tabular}

Source CBS, 2005a

and four percent per year in the Mountain and Tarai regions, respectively, whereas the reduction was only two percent in the Hills.

Theincome, consumption and employment levelshavealso improved between the two N LSS periods. Although, the percentage of households having land has declined, and the parcels have been fragmented further, the share of ir rigated land and the share of non-farm income have increased (T able 2.3).

Thenominal per capita consumption increased from Rs. 6,802 in 1995/ 96 to Rs. 15,848 in 2003/ 04- up byabout 16.6 percent peryer. A mongthepoorest population quintile, consumption has increased from Rs. 2,571 to Rs. 4,913, an annual increase of 11.3 percent. Theshareof non-farm incomein household incomehasincreased from 39 percent in 1995/ 96 to 52.2 percent in 2003/ 04 (Table2.3). 
Remittanceshaveremained steady, and wereresponsiblefor raising non-farm income and consumption. The government's focus on rural infrastructures and the social sector also helped to improve basic service delivery and the access of people to the services (Box 2).

The relationship between poverty and growth in per capita real expenditure during the two N LSS periods shows a negative 0.6 , indicating a reduction in poverty by 6 percentage points with every 10 percent increase in per capita expenditure. Theestimates for thegrowth poverty elasticity are 1.33 for urban and 0.74 for the rural areas (CBS, 2005).

\section{Table 2.3: Selected comparative indicators of NLSS I and N LSS II}

Activities

A. Agriculture

1. H ouseholds with land (\% of total households)

2. Average size of agricultureland (ha.)

3. \% of irrigated land

B. Consumption (Rs.)

1. N ominal per capita consumption

All N epa

Poorest 20\%

Richest 20\%

2. Share of nominal per capita consumption

Poorest 20\%

Richest 20\%

C. Income (Rs)

1. National averageH $\mathrm{H}$ income

2. National aver age per capitaincome

$$
\text { All Nepal }
$$

Poorest 20\%

Richest $20 \%$

3. Share of farm incomein household income(\%)

4. Share of $\mathrm{N}$ on-farm incomein household income (\%)

D. Employment Status

1. Percentage employed

2. Labour force participation rate

3. U nemploymentrate

Aged $10-14$ years

Age 15-24 years

E. Remittances and Transfers

1. Percentage of all households receiving remittances

2. Average amount of remittances per receiving households 15,160

3. Share of remittances received by households

4. Share of remittances in total household income among recipients
NLSS I NLSS II \%

1995/96 2003/04 Change

$83.1 \quad 77.5 \quad-5.6$

$\begin{array}{lll}1.1 & 0.8 & -27.2\end{array}$

$39.6 \quad 54.3 \quad 14.7$

$\begin{array}{rrr}6802 & 15848 & 133.0 \\ 2571 & 4913 & 91.1 \\ 15243 & 42236 & 177.1\end{array}$

$\begin{array}{lll}7.6 & 6.2 & -1.4\end{array}$

$\begin{array}{lll}44.9 & 53.3 \quad 8.4\end{array}$

$\begin{array}{lll}43732 & 80111 & 83.2\end{array}$

$\begin{array}{lll}7690 & 15162 & 97.2\end{array}$

$2020 \quad 4003 \quad 98.2$

$\begin{array}{lll}19325 & 40486 \quad 109.5\end{array}$

$\begin{array}{lll}61 & 47.8 & -13.2\end{array}$

$\begin{array}{lll}39 & 52.2 & 13.2\end{array}$

$\begin{array}{lll}67.2 & 74.3 & 7.1\end{array}$

$\begin{array}{lll}70.6 & 77.2 & 6.8\end{array}$

$\begin{array}{lll}4.9 & 3.8 & -1.1\end{array}$

$\begin{array}{lll}7.9 & 3.4 & -4.5\end{array}$

$\begin{array}{lll}7.3 & 6.0 & -1.3\end{array}$

$\begin{array}{lrr}23.4 & 31.9 & 8.5\end{array}$

$34,698-129.0$

$\begin{array}{llr}26.6 & 35.4 & 8.8\end{array}$

Source CBS, 1996 and 2004 
$N$ epal's poverty could have been reduced further had it not been for income inequality, in general, and al so among different social groups. Incomeinequality rose from 0.34 to 0.41 as measured by the $G$ ini coefficient between the two surveys. A Iso despite the overall reduction in poverty, the outcomes are not uniform among different social groups, especiallywomen, Dalits (considered "untouchable") and Janajatis (especially among the disadvantaged indigenous nationalities). The following factors were responsible for bringing the overall poverty levels down:

- Real GDP grew by about four percent per year from 1996 to 2004 while there was a decline in population growth, fertility and household size resulting in higher per capita and per household income

- Agricultural growth remained higher than the population growth rate (2.25\%) resulting in more per capita food availability

- Crop diversification and the move towards high-value crops and meat and eggs and horticulture contributed to higher incomes for farming households

- Expansion of literacy and skill training, and availability of credit at the grassroots level

- Growth of remittances by morethan 25 percent annually and theincrease in thenumber of households receiving remittances (from 23\% in 1995/ 96 to $32 \%$ in 2003/ 04)

- Improved employment opportunities in the service sector, and

- Improved basic services as result of increasing government expenditures in health, education and drinking water and al so higher awareness about availability of the services.

\section{The Tenth Plan/PR SP}

The PRSP/Tenth Plan aims to reduce poverty from 38 percent in 2001/ 02 to 30 percent in 2006/ 07. A ccording to the N LSS 2004, N epal has almost met this target. The PRSP is anchored on a four-pillar strategy to attain the target (Box 3). The first strategy intends to achieve high and sustained broadbased growth by promoting faster non-agricultural growth, creating an investment friendly environment through liberal economic policies and by focusing on agriculture for raising income, employment and ensuring food security in rural areas. 


\section{Box 3: The four PRSP pillars}

1. High, broad-based and sustainable economic growth

2. Improvement in access and quality of infrastructure, social and economic services in therural areas

3. Targeted programmesfor social and economic inclusion of thepoor and marginalised communities, and

4. Good governanceto improveservicedelivery, efficiency, transparency and accountability.

The second pillar focuses more on improvements in access, and quality of infrastructures as well as on the availability of social and economic services. Improvements in quality and availability of better roads, electricity and communications systems are needed for achieving high and sustained growth and ensuring effective public service delivery.

Thethird PR SP strategy comprises of safety netsfor excluded and vulnerable groups - women, Dalits, Janajatis, children and senior citizens. The fourth MTEF has introduced pro-poor and gender budgeting to ensure that development benefits reach the excluded groups.

The PRSP emphasises effective programme implementation and service delivery through governancer eforms. A number of measures havebeen taken, including, the rightsizing of thebureaucracy and devolving morefunctionsto local bodies, streamlining planning and budgeting, improving prioritisation of programmes and projects, introducing pro-poor and gender budgeting, improving resource mobilisation and involving local communities in development at the grassroots level.

ThePRSP al so stressesmaintaining macroeconomic stability and implementing structural and policy refor ms in key areas. The policy changes are important for meeting both the Tenth Plan objectives as well as the MDGs. Annual poverty monitoring, monitoring of other targets and processes are integral for the effective implementation of planned activities.

\section{Millen nium Development Goals}

Nepal adopted the Millennium Declaration in 2000 committing to work towards attaining theM illennium D evelopment G oals (M D G s) by 2015. The M D G scomewith quantitativetargetsfor poverty reduction, and improvements in health, education, gender equality, the environment and general human 
development. The Tenth Plan/PRSP targets encompass many of the MDG targets that $\mathrm{N}$ epal aims to attain over three five-year plan periods. The prioritisation of programmes and assurance of resources to priority programmescontributetowards better outcomes and poverty reduction. There is evidence of this in the Global Monitoring Report on the Millennium D evelopment G oals(World Bank-IM F, 2006). Thereport saysstrong economic growth, backed by improved policies in developing countries and increased aid has resulted in reduced child deaths, rapid gainsin primary school enrolment and reduced H IV / A ID S infection rates in some of the countries surveyed.

There is a separate mechanism for reporting progress on the MDGs. Two reports (2002 and 2005) have been produced so far and these detail the achievements and shortcomings and suggest corrective strategies. Table 2.4 shows N epal's achievements vis-àvis the M D Gs, the Tenth Plan targets and the longer-term goals to be attained by 2015. Except for the goals set for universal primary education and combating HIV/ AIDS, N epal may be able to attain all other MDG targets.

In terms of universal primary education, whilenetenrolment in primary school may lag behind the MDG target, the completion of the primary cycle is attainable while meeting the enrolment targets would require greater efforts to target children from "hardcore" poor families and girls. Similar efforts are needed for attaining the other targets such as reducing maternal mortality.

The government has taken several MDG-related initiatives in recent years. These activities include scaling up programmes and resource prioritisation, capacity building, building awareness and district-level M D G -focussed periodic plansand resourceprioritisation. A needsassessment study for attainingM D Gs has also been completed. The study etimates a financing gap of US\$ 7.9 billion during the period from 2005 to 2015, assuming a relatively quick resolution of the conflict (A nnex 2.1). The government has also begun preparing district-level MD G progress report in five districts on a pilot basis. A district-level needs assessment for achieving MDGs is also underway in Rupadehi district. 


\section{Table 2.4: Millennium Development G oals 2005-2015}

\begin{tabular}{|c|c|c|c|c|c|c|}
\hline Goal / target & & Status & & $\begin{array}{l}\text { Tenth plan } \\
\text { target }\end{array}$ & $\begin{array}{l}\text { MDG } \\
\text { target }\end{array}$ & $\begin{array}{l}\text { Achievement } \\
\text { possibility }\end{array}$ \\
\hline & 1990 & 2000 & 2005 & 2007 & 2015 & \\
\hline $\begin{array}{l}\text { Goal-1: Eradicate extreme pover ty and hunger } \\
\text { Target-1 Eradicatepoverty by half }\end{array}$ & & & & & & Likely \\
\hline a. \% of population below $\$ 1 /$ day (PPP value) & 33.5 & NA & 24.1 & & 17 & \\
\hline b. \% of population below poverty line & 42 & 38 & 31 & 30 & 21 & \\
\hline Target-2Reducehunger by half & & & & & & Possible \\
\hline $\begin{array}{l}\text { a. \% of population below minimum level of dietary } \\
\text { energy consumption }\end{array}$ & 49 & 47 & NA & & 25 & \\
\hline b. \% of underweight children aged 6-59 months & 57 & 53 & NA & & 29 & \\
\hline c. $\%$ of stunted children age $6-59$ months & 60 & 55 & NA & & 30 & \\
\hline $\begin{array}{l}\text { Goal-2: Achieve universal primary education } \\
\text { Targe-3Ensureprimaryshooling }\end{array}$ & & & & & & Unlikely \\
\hline a. Net enrolments in primary education (\%) & 64 & 81 & 84 & 90 & 100 & \\
\hline b. \% of pupils starting gradel and reaching grade 5 & 38 & 63 & 76 & & 100 & \\
\hline c. Literacy rate $15-24$ year olds & 49.6 & 70.1 & 73 & & 100 & \\
\hline $\begin{array}{l}\text { Goal-3: Promote gender equality and empower } \\
\text { women }\end{array}$ & & & & & & Possible \\
\hline Target-4Eliminategender disparity in education & & & & & & \\
\hline a. Ratio of girls to boys at primary leve & 0.56 & 0.79 & 0.86 & 1.0 & 1.0 & \\
\hline b. Ratio of girls to boys at secondary level & 0.43 & 0.70 & 0.82 & 1.0 & 1.0 & \\
\hline c. Ratio of girls to boys at tertiary level & 0.32 & 0.28 & NA & & 1.0 & \\
\hline d. Ratio of literatewomen to men $15-24$ year olds & 0.48 & NA & 0.73 & & 1.0 & \\
\hline $\begin{array}{l}\text { Goal-4: Reduce child mortality } \\
\text { Target-5 ReduceU 5MR by twothirds }\end{array}$ & & & & & & Likely \\
\hline a. Infant mortality rate (IMR) & 108 & 64 & 61 & 45 & 34 & \\
\hline b. Under fivemortality rate & 162 & 91 & 82 & 72 & 54 & \\
\hline c. Proportion of lyear old immunised against measles & 42 & 71 & 85 & & $>90$ & \\
\hline $\begin{array}{l}\text { Goal-5: Improve mater nal health } \\
\text { Target-6 ReduceMMR by threquarters }\end{array}$ & & & & & & Possible \\
\hline a. M aternal mortality rate (M MR) & 850 & 415 & NA & 300 & 213 & \\
\hline b. $\%$ of deliveries attended by health care providers & 5 & 11 & 20 & & 60 & \\
\hline $\begin{array}{l}\text { Goal-6 Combat HIV/AIDS, malaria and other } \\
\text { diseases }\end{array}$ & & & & & & Unlikely \\
\hline Target-7 Reversethespred of HIV/ AIDS & & & & & & \\
\hline a. HIV/AIDS prevalence among $15-49$ year olds (\%) & NA & 0.29 & 0.5 & & & \\
\hline b. Contraceptive prevalence rate & 24 & 39 & NA & & 67 & \\
\hline Goal-7: Ensure environmental sustainability & & & & & & \\
\hline Target-9 Reversethe lossof envir onmental resurces & & & & & & Possible \\
\hline a. A rea under forests & 37 & 29 & 29 & & & \\
\hline Target-10 A ccessto safedrinkingwater & & & & & & Likely \\
\hline a. $\%$ of population with improved water sources & 46 & 73 & 81 & 85 & 73 & \\
\hline b. \% of population with improved sanitation & 6 & 30 & 39 & & 53 & \\
\hline $\begin{array}{l}\text { Goal-8: D evelop global partnership for } \\
\text { development }\end{array}$ & & & & & & \\
\hline
\end{tabular}

Source NPC/UNDP, 2005 


\section{Macroeconomic Performance and Challenges}

\section{SUSTAINING MACROECONOMIC STABILITY}

Macroeconomic stability remained a major challenge during the first three years of the PRSP/Tenth Plan due to both the conflict - and increasing pressure of security spending - and political uncertainty. However, the government did manageto maintain a sound macroeconomic balancethrough increased efforts to mobilise revenue and proper utilisation of resources through the MTEF. The classification of the budget, as current and capital, and the prioritisation of all programmes/ projects as P1, P2 and P3 in terms of their priority, have helped guarantee funding to programmes with highest priority. As a result of these initiatives, the GDP has begun to grow howsoever slowly - after contracting in 2001/ 02. Revenue collection has also remained buoyant, domestic borrowingand inflation remained low and balance of payments remained robust. Continued growth in remittances also helped the economic recovery process.

Grassroots programmes have been aided by the devolution of selected tasks and functions to local bodies that have been provided both unconditional and conditional grants. There has been progressin rural infrastructure, income generation and poverty reduction programmes carried out through participatory processes.

O verall GDP growth: The first three years of the Tenth Plan recorded lower growth than the target. The GDP grew by 3.1 percent in 2002/ 03, up from acontraction $(-0.4)$ percent in $2001 / 02$. Theeconomy grew by 3.6 percent in 2003/ 04 and slowed down again in 2004/ 05 (2.4\%). Low agricultural production - owing to the weather - and a contraction in non-agricultural activities, due to the conflict and political instability, were responsiblefor the slowdown.

On average, agriculture sector growth was above 3.1 percent during 2003 to 2005 but was less than target and ther eforewas not enough to make a major impact on poverty reduction. $\mathrm{N}$ on-agricultural growth was 3.4 percent during the first two years of the Plan period but declined to 2.1 percent in 2004/ 05. 
Savings and investment: Total investment in the economy was around 25 percent of GDP during the first threeyears of the Plan. In 2001/ 02 (the base year of the PRSP), the investment to GDP ratio was 24.2 percent. Theratio rose to 25.8 percent in 2002/ 03 and to 26.4 percent in 2003/04. H owever, the ratio slid to 25.7 percent in 2004/ 05 (Table 3.1). Private sector investment made up more than three fourths of the tota, and the gross private capital for mation to GDP ratio reached 76.6 percent of total investment in 2004/ 05. The capital formation in the public sector has been declining since 2001/ 02.

Gross domestic savings remained at over 12 percent of GD P during the first thre years of the Tenth Plan. It was 12.1 percent in 2001/ 02, rose to 12.6 percent in 2003/ 04 and remained at the samelevel in 2004/ 05. G rossnational savings declined from 16.5 percent in 2001/ 02 to 14.5 percent in 2004/ 05.

Fiscal balance: Revenue remained buoyant during the Plan period. It rose from 11.9 percent of GDP in 2001/ 02 to about 13.3 percent in 2004/ 05 . The implementation of ASY CUDA at major custom points and reforms in tax administration (making VAT and PAN registration mandatory), including the widening of the tax net, contributed to the revenue growth.

Regular expenditureincreased during thePlan period. It rosefrom 11.5 percent of GDP in 2001/02 to 12.4 percent of GDP in 2004/05. However, development spending continued to decrease; it dropped from 7.4 percent of GD P in 2001/ 02 to 6.5 percent in 2004/ 05. The conflict and the absence of elected local bodies werereasons for the slowdown. Theslow spending eased the pressureon domestic bor rowing, which remained at 2 percent of GDP in gross terms ( $1.5 \%$ net) during the period, despite the increasing demand for recurrent expenditure.

Foreign aid roseslightly, from 3.4 percent in 2001/ 02 to 3.7 percent in 2004/ 05 and grant aid accounted for 2.1 percent of GDP in 2004/ 05. 
Table 3.1: Performance of macroeconomic indicators in current prices (2001/02-2005/06)

\begin{tabular}{|c|c|c|c|c|c|}
\hline \multirow{2}{*}{ 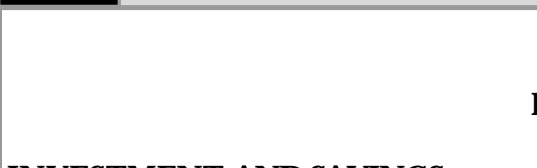 } & \multicolumn{5}{|c|}{ (Percent of GDP in producers prices) } \\
\hline & \multirow[t]{2}{*}{$\begin{array}{c}\text { 2001/ } 02 \\
\text { Base year }\end{array}$} & \multirow[t]{2}{*}{$\begin{array}{l}\text { 2002/ } 03 \\
\text { Actual }\end{array}$} & \multirow[t]{2}{*}{$\begin{array}{c}\text { 2003/04 } \\
\text { Actual }\end{array}$} & \multirow[t]{2}{*}{$\begin{array}{c}\text { 2004/05 } \\
\text { Actual }\end{array}$} & \multirow[t]{2}{*}{$\begin{array}{l}\text { 2005/ } 06 \\
\text { Budget } \\
\text { estimates }\end{array}$} \\
\hline IN VESTMENT AND SAVINGS & & & & & \\
\hline Total investment & 24.2 & 25.8 & 26.4 & 25.7 & \\
\hline Privateinvestment (including change in stock) & 16.6 & 19.0 & 19.9 & 19.7 & \\
\hline Gross national savings & 16.5 & 15.5 & 15.2 & 14.5 & \\
\hline Gross domestic savings & 12.1 & 12.0 & 12.6 & 12.6 & \\
\hline \multicolumn{6}{|l|}{ GOVERNMENT FIN ANCE } \\
\hline Government revenue & 11.9 & 12.3 & 12.5 & 13.3 & 14.1 \\
\hline Total expenditure & 18.9 & 18.4 & 18.0 & 18.9 & 21.9 \\
\hline Regular expenditure & 11.5 & 12.0 & 11.8 & 12.4 & 12.9 \\
\hline D evelopment expenditure & 7.4 & 6.4 & 6.2 & 6.5 & 9.0 \\
\hline Current expenditure & 11.6 & 11.4 & 11.2 & 11.8 & 13.1 \\
\hline Capital expenditure & 5.9 & 4.9 & 4.6 & 4.7 & 6.4 \\
\hline Principal repayment & 1.5 & 2.1 & 2.2 & 2.4 & 2.4 \\
\hline $\begin{array}{l}\text { C apital expenditure (including principal } \\
\text { repayment) }\end{array}$ & 7.4 & 7.0 & 6.8 & 7.1 & 8.8 \\
\hline Revenuesurplus & 0.4 & 0.3 & 0.8 & 0.9 & 1.2 \\
\hline Government revenue-current expenditure & 0.4 & 0.9 & 1.4 & 1.5 & 1.0 \\
\hline Budgetary deficit & 5.4 & 3.6 & 3.2 & 3.5 & 4.6 \\
\hline Total foreign aid & 3.4 & 3.5 & 3.8 & 3.7 & 5.7 \\
\hline Grant & 1.6 & 2.5 & 2.3 & 2.1 & 3.2 \\
\hline Loan & 1.8 & 1.0 & 1.5 & 1.7 & 2.5 \\
\hline Total domestic bor rowings & 3.6 & 2.6 & 1.7 & 1.8 & 2.0 \\
\hline D omestic borrowings & 1.9 & 1.9 & 1.1 & 1.7 & 2.0 \\
\hline C ash balance ( - surplus) & 1.7 & 0.7 & 0.5 & 0.1 & 0.0 \\
\hline \multicolumn{6}{|l|}{ MONETARY DATA } \\
\hline N arrow money supply (M 1) & 18.2 & 18.3 & 18.9 & 18.8 & 20.2 \\
\hline Broad money supply (M 2) & 53.0 & 53.8 & 55.8 & 56.3 & 60.8 \\
\hline Total domestic credit & 49.0 & 50.0 & 50.5 & 53.4 & 50.9 \\
\hline N et foreign assets & 20.9 & 20.0 & 21.9 & 20.2 & 22.3 \\
\hline \multicolumn{6}{|l|}{ BALANCE OF PAY MENT } \\
\hline Exports & 11.1 & 10.9 & 10.9 & 10.9 & 10.3 \\
\hline Imports & 25.4 & 27.2 & 27.4 & 24.8 & 24.6 \\
\hline Current account balance (-deficit) & 4.3 & 2.5 & 2.9 & 5.5 & 4.0 \\
\hline Remittances & 11.2 & 11.9 & 11.8 & 12.3 & 12.4 \\
\hline Balance of payments (-deficit) & -0.8 & 1.0 & 4.0 & 1.1 & 1.0 \\
\hline Gross for eign exchangereserves & 25.0 & 23.7 & 26.2 & 24.3 & 24.8 \\
\hline
\end{tabular}

Sources CBS, 2005 and 2006; NRB, 2005; N PC, 2005; and N PC, 2005 
Trade and balance of payments: There was a general slowdown in trade exports to GDP ratio fell slightly, from 11.1 percent to 10.9 percent during thefirst threeyears of thePR SP. There has been a major declinein theexport of readymadegarments, especially after J anuary 2005, when quotaswere phased out as part of theWT 0 arrangement. Imports grew during thefirst two years of the Plan, from 25.4 percent of GDP in 2001/ 02 to 27.4 percent in 2003/ 04 and then declined to 24.8 percent in 2004/ 05.

N epal's major exports overseas have remained low. Readymade garment exports overseas declined by about 17.6 percent while that of Pashmina dropped by about 4.6 percent in the first eight months of 2004/ 05. Thedrop in garment exportsresulted in loss of jobsbecausemany factorieswereforced to downsize or shut down.

$N$ epal had a current account deficit of about 4.3 percent of GDP in 2001/ 02 , the base year of the PRSP. The deficit nar rowed in the first two years of the Plan (declining to -2.5 percent and -2.9 percent in 2002/ 03 and 2003/ 04, respectively). H owever, the deficit widened to 5.5 percent of GDP in 2004/ 05. Thecur rent account deficitresulted from a widening tradegap and declining servicereceipts, including receiptsfrom tourism. The declinein servicereceipts was partly balanced by transfers, mainly remittances from $\mathrm{N}$ epalis working overseas. Remittances rose from 11.2 percent of GDP in 2001/ 02 to 12.3 percent of GDP in 2004/ 05.

N epal had a balanceof paymentssurplusduringthereview period. Theforeign exchangereserves declined to 24.3 percent of GDP in 2004/ 05 from around 26.2 percent in end-2003/ 04. Thereserveswereenough to cover 11.5 months of merchandise imports. Exchange rate of the $\mathrm{N}$ epali Rupee against the A merican dollar stabilised at about Rs. 71: U S\$ 1 and the real exchange rate, remained within acceptable levels during the review period.

M onetary measures: TheN epal R astra Bank (central bank) maintained tight monetary control duringthePlan period. Broad money grew from 9.8 percent in 2002/ 03 and to 12.8 percent in 2003/ 04 but declined to 8.3 percent in 2004/05. D omestic credit recorded an 11 percent annual growth during the Plan period. Private sector borrowing was around 68 percent of the total, slightly lower than thetarget (70\%). Thegovernment borrowed less from the banking sector, largely because it was unable to speed up development expenditure. Inflation was around 4 percent (average) during the first three years of the Plan. 


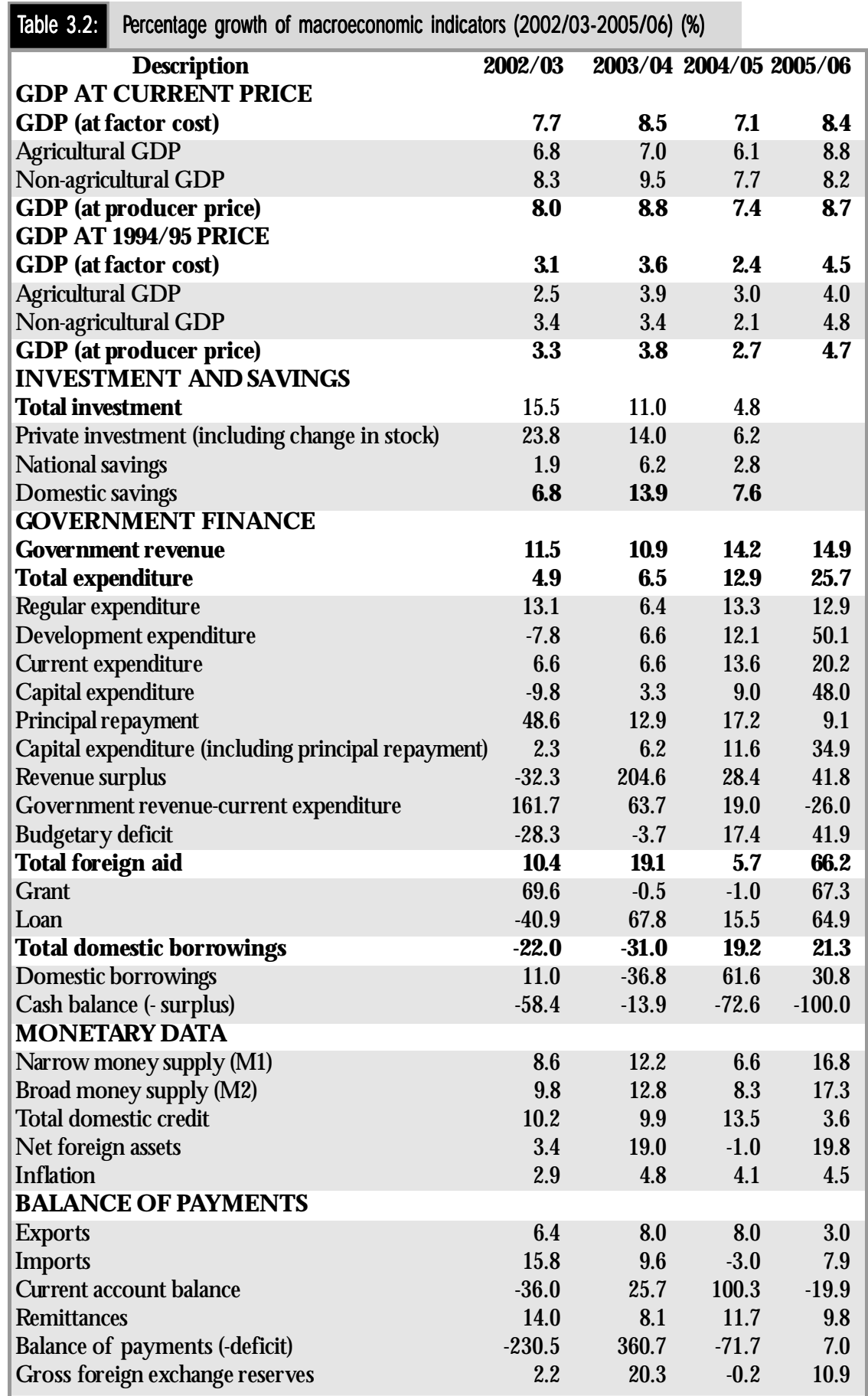

Sources CBS, 2005 and 2006; NRB, 2005; N PC, 2005 ; and N PC, 2005 
Poverty reduction growth facility: Theimplementation of thePRSP made $N$ epal eligiblefor borrowingfrom both thePoverty R eduction $G$ rowth $F$ acility (PRGF) of thel nter national M onetary Fund (IM F) and thePoverty Reduction Support Credit (PRSC) of the World Bank. In N ovember $2003 \mathrm{~N}$ epal began borrowing under thePRGF, and also obtained a PRSC credit from the World Bank. The PRGF allows credit of up to U $\$ 73.9$ million from the IMF, of which $\mathrm{N}$ epal drew thefirst tranche of U $\$ \mathbf{1 0 . 6}$ million in N ovember 2003. It also drew the second tranchebut has not borrowed thereafter owing to delays in fulfilling "prior commitments". N epal borrowed U $\$ \$ 70$ million from the World Bank in 2003.

Public debt management: Nepal has begun to strengthen public debtrecords with technical assistance from the A sian D evelopment Bank. The assistance has included instal ling state-of-art computer software (C S-D RM S 2000+) at the MOF, FCGO and NRB for managing information. A macro-modelling exercise has been completed to assess debt sustainability and 37 persons have been trained on the use of the software.

\section{NEW INITIATIVES IN ECONOMIC MANAGEMENT}

The government has continued reforms for ensuring sound macroeconomic management and stability. These measures seek to maintain fiscal discipline, ensure efficiency of public resources, monetary and external sector stability, strengthen the financial system and governance, and expand the role of the private sector.

The government has broadened the MTEF to cover all ministries and expenditure items for ensuring fiscal discipline and prudent expenditure management. A ctions have also been taken to improve domestic resource mobilisation by broadening the tax base, clearing and settling tax arrears, narrowing tax exemption, revising custom valuation and strengthening the tax administration.

A II monetary instruments have been mobilised for controlling inflation. But the effortshaveremained short of full effectiveness owing to external shocks, mainly caused by therise in international oil prices. Effortsarealso underway to attain targets for broad money supply, limiting domestic credit and government borrowing and for expanding open market operations. The government hasalso prepared plansfor diversifying exportsand for promoting foreign direct investment. 
The regulatory and supervisory capability at the central bank has been strengthened and the programmefor reforming state-owned banks has begun to show results. The contracts for external managers at the two commercial banks have been extended.

N epal hassimplified procedures for tradeand investment. A new Labour and Employment Policy has been adopted and a draft to revise the Labour Act was prepared (and approved in early 2006). M easures have al so been taken to improve and standardise accounting, auditing and reporting systems.

The Labour and Employment Policy 2006 replaced the Labour Policy, 1999. Itslong-term objectiveisto createa favourableinvestment climateby enhancing workforce productivity, generating decent and productive employment opportunities, and ensuring worker rights. The policy also highlights the importance of generating additional jobs by setting up special economic zones and export-oriented industries. The policy also seeks to increase access for women, Dalits, Janajatis and people displaced by the conflict, and to eradicate child labour.

Thegovernment hasenacted ordinancesfor secured transactionsand to amend the company law. The Secured Transaction O rdinance makes it possible for securing credit against moveable property; under the old provisions only immovable assets (land and buildings) could be used for the purpose. The amendments in the Company Act simplify investment procedures; clarify ownership rules and the role of the Company Registrar's $O$ ffice. The Bank and Financial Institutions O rdinance, 2005 further consolidates the finance sector, including the regulatory environment. 



\section{Public Expenditure Management}

\section{Overview}

N epal has been a fiscally responsiblestate, and has progressed toward attaining the Poverty Reduction Strategy (PRS) objectives ${ }^{1}$ The achievements include creation of fiscal spaceto increasespending on pro-poor programmes, prudent macroeconomic policies, improved expenditure management, and reforms that cover, among others, the financial sector, service delivery, governance, and donor har monisation. Theseareimportant achievementsgiven theongoing conflict and the political instability $\mathrm{N}$ epal has had during the PRS implementation period. Thereforms have been deepened to protect thegains by consolidating theinitiativesthrough institutionalisation of theinter ventions. Expenditure management reform, especially the deepening of the M edium Term Expenditure framework (MTEF), is one of many initiatives underway. The MTEF has aligned resources to PRS outputs.

\section{MTEF AND FISCAL PERFORMANCE}

Macro-level government operation \& aggregate fiscal discipline: In the $\mathrm{N}$ inth Plan, N epal financed expenditure, equalling al most 18 percent of GDP, through revenues $(11 \%)$, foreign financing $(5 \%)$ and domestic borrowing, which averaged 2.3 percent of GDP. Current expenditure was successfully limited to 11 percent of GDP (at the level of domestic revenue), allowing capital for mation of seven percent. Thegovernment has been ableto maintain aggregate fiscal discipline, despite the difficult development environment and arisein security expenditure. A sa share of GD P, between 2002 and 2005, the government financed its total expenditure of 19 percent of GDP through revenues (13\%), foreign funds (4\%) and rest through domestic borrowing, which averaged about two percent of GDP (Table 4.1).

Current expenditure is rising and it now comprises 74 percent of total expenditure (or $14 \%$ of GDP), of which, debt payment is three percent of GDP. Debt servicing is increasing with the maturity of loans taken in the early 1990s. In contrast, capital expendituregrowth ison adecline; it comprised

\footnotetext{
${ }^{1}$ Second PRS Progess Report (June2005)
} 


\begin{tabular}{lrrrr|}
\hline Table 4.1: & Government operation (As percent of G DP) \\
\hline & N inth Plan & $\begin{array}{r}\text { PRS Years } \\
\text { 2002- 2005 }\end{array}$ & $\begin{array}{c}\text { A ctual of } \\
\text { Fiscal Year 05 }\end{array}$ & Budget 06 \\
Total revenue & 11.42 & 12.72 & 13.26 & 14.30 \\
Total expenditure & 18.31 & 18.61 & 19.38 & 22.18 \\
Total current expenditure & 11.52 & 13.70 & 14.22 & 15.67 \\
0/ w security & 2.23 & 3.33 & 3.53 & 3.46 \\
o/ w principal payment & 1.39 & 2.28 & 2.56 & 2.41 \\
Total capital expenditure & 6.79 & 4.91 & 5.17 & 6.51 \\
Total external financing & 4.56 & 3.92 & 4.48 & 5.81 \\
Total domestic financing & 2.34 & 1.97 & 1.65 & 2.07 \\
\hline
\end{tabular}

five percent of GDP in 2005 compared to six percent of GDP (average) during the $\mathrm{N}$ inth Plan.

Revenue, as a percentage of GDP, is growing. In 2005, revenue was 13.3 percent of GD P up from the average (11.4\%) during the N inth Plan; and, on average, aid expenditure (grant and loan) was 4 percent of GDP. Domestic bor rowing, resulting from conflict related slow-down in budget useand macro framework capping levels, has been on a declinefrom 2.3 percent (of average GDP) in the N inth Plan to 1.7 percent of GDP in 2005.

Nepal has maintained aggregate fiscal discipline despite a weak economy, declining aid and increasing security expenditure and debt repayment obligations. It managed competing claims on resources to avoid large fiscal deficits by sacrificing capital expenditure and lowering domestic borrowinga cost to future growth. The government has also increased pro-poor expenditure, which averaged around 30 percent during N inth Plan, to 34 percent - thetarget for 2005/ 06. Whilestabilisation targets havelargely been met, it does raise a question on the role of fiscal policy - especially the stabilisation vs. growth and poverty reduction trade-off - and calls for analysis to identify ways to create fiscal space for growth.

Allocation efficiency - Inter sectoral allocation: Poverty reduction targets can be met if social sector investment for attaining meaningful outputs is raised. Investment in the social sector - education, health and drinking water/ sanitation - is important for achieving the Tenth Plan objectives of reducing poverty and improving human development. Towards that end, social sector spending has increased, assisted mainly by two SWA Ps. A s a percentage of GDP, social sector spending increased from an average of 5.65 percent in the $\mathrm{N}$ inth Plan to six percent in 2004/ 2005 and is budgeted to reach 7.5 percent 
of G DP in 2005/ 06. Lookingahead, theavailability of resources for education and health through SWA p arrangements is expected to increasetheinvestment share of these two sectors. In nominal terms, expenditure in education increased from an average of Rs. 9.75 billion in the N inth Plan to Rs. 16 billion in 2004/ 05 (estimated); and that for health rose from Rs. 3.4 billion to Rs. 5 billion in the same period (T able 4.2).

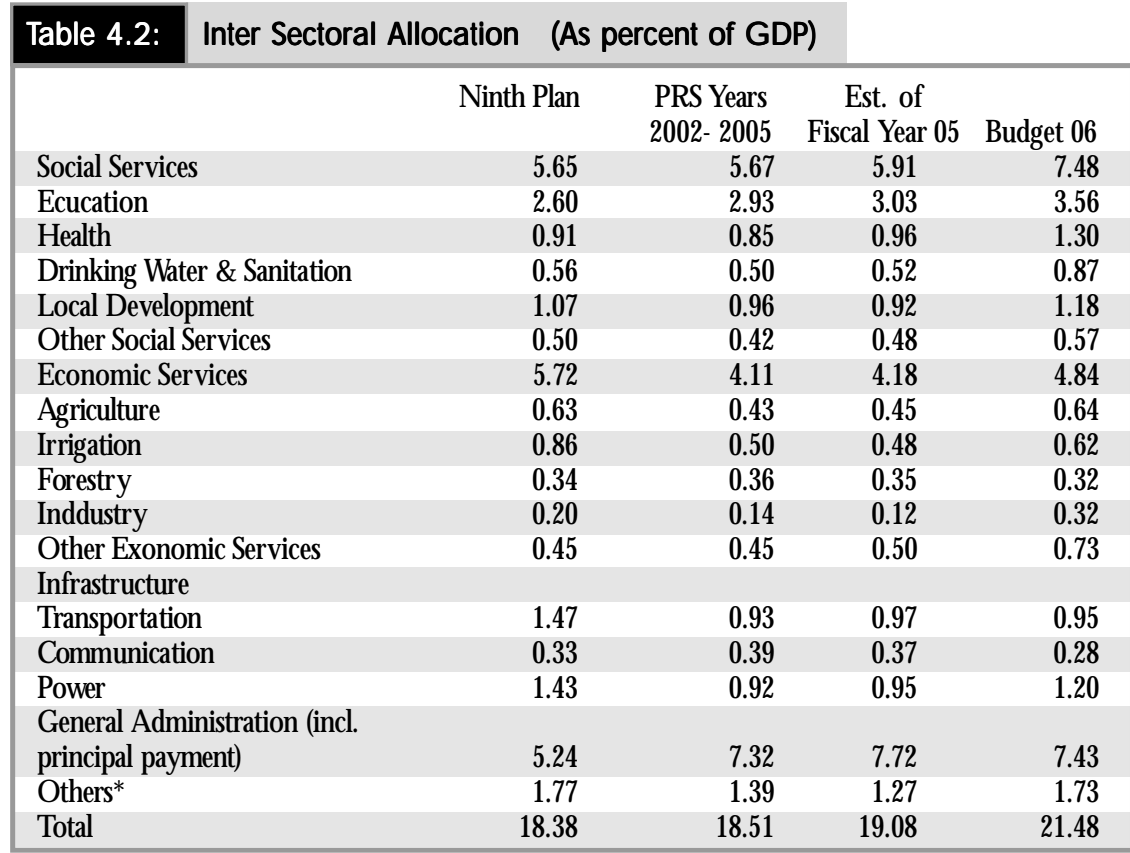

* Royal Palace, Consitutional Body and Miscellaneous

However, spending in the economic sector has declined from an average of 5.7 percent of GDP in the N inth Plan to 4.1 percent of GDP in 2004/ 05. The decline is due to completion of high cost investments in power and transport in early years of the Tenth Plan. A mong other reasons for low investment, was the conflict related slow-down in development activities and a lower number of new projects in the pipeline.

Investments in transport and power lead spending in the economic sector. Thesetwo sectorsaccount for half of all economic sector spending. In nominal terms, the investment in these two sectors is at the level of the $\mathrm{N}$ inth Plan, averaging at around Rs. 10 billion per year. Spending on highways has declined while that on rehabilitation and maintenance has been increasing. $H$ owever, spending on maintenance has not been at par with rehabilitation and this 
remainsa concern from the point of view of cost efficiency, and al so because timely attention on the status of roads is an important outcome indicator of the PRS.

Rural development (agriculture, irrigation and forestry sectors) as percent of GDP has been on a decline from an average of 1.8 percent of GDP in the $\mathrm{N}$ inth Plan period to 1.3 percent of GDP in the first thre PRS years. U pon completion of the Business Plan or sector strategy, resources will be tightly aligned to meet the PRS outcomes.

Technical efficiency - Pro-poor expenditure is increasing: O ne major outcome of expenditure reform, with the MTEF anchoring the PRSP, is the increase of pro-poor spending. Pro-poor expenditure as percentage of the total increased from 30 percent in 2002/ 03 to 31.4 percent in 2004/ 05 and is budgeted to increaseto 35 percent in 2005/ 06. In nominal ter ms, thistranslates into a 78 percent increase in pro-poor expenditure(or increase of expenditure from Rs. 25 billion in FY 2002/ 03 to the budgeted Rs. 45 billion in 2005/ 06). In sectoral terms, pro-poor expenditure is increasing in the social sector. In 2004/ 05, the share of pro-poor social sector expenditurewas 76 percent of total social sector spending, led by education (81\% pro-poor expenditure in total education expenditure) and health (69\% pro-poor expenditure in the total health spending). These two sectors have SWAp funding focused on increasing investment on primary school enrolment and expansion of essential heal th care services (Table 4.3).

\begin{tabular}{|lrrr|}
\hline Table 4.3: & Secotral pro-poor expenditure (as percentage of total expenditure) \\
\hline & PRS Years & Est. of \\
2002- 2005 & Fiscal Year 05 & Budget 06 \\
Social services & 23.45 & 23.71 & 26.75 \\
\hline Education & 13.03 & 13.02 & 13.86 \\
Health & 3.13 & 3.42 & 4.03 \\
Drinking water \& sanitation & 1.34 & 1.54 & 2.08 \\
Local development & 4.76 & 4.40 & 5.27 \\
Economic services & 7.35 & 7.72 & 8.58 \\
Agriculture & 1.87 & 1.84 & 2.27 \\
Irrigation & 1.87 & 1.20 & 1.31 \\
Forestry & 0.40 & .029 & 0.20 \\
Infrastructure & 3.07 & 3.61 & 3.45 \\
Transportation & 1.31 & 1.70 & 1.29 \\
Power & 1.76 & 1.91 & 2.17 \\
Total & 30.81 & 31.44 & 35.34 \\
\hline
\end{tabular}


In 2004/05, the propoor spending in the economic sector was 35 percent of the sector's total expenditure(or 7.7 percent of total expenditure), and it is budgeted to reach nine percent of the total in 2005/06. Rural development (agriculture, irrigation and forest), transport and power sectors lead in the propoor expenditure cat-

egory within theeconomic sector. A lthough declining, income-generating activities (cash crops, poultry and livestock rearing) have hel ped the agriculture sector to maintain pro-poor expenditure at two percent of the total. Backed by a policy of providing subsidies to communities for power generation and distribution, rural electrification leads the power sector and maintains two percent pro-poor spending in the total expenditure and this is expected to continue in the future.

Funds controlled by communities have grown. Aware of need to involve beneficiaries to implement the programmes they pick - as articulated in the PRS - theflow of fund to such programmes has been raised from a low base of 1.8 percent of total expenditure in 2001/ 02 to five percent in 2004/ 05 and is budgeted to increase further in 2005/ 06. The level of block grants to local bodies remains at previous levels.

Towards the implementation of the government's devolution policy, from 2005/ 06 the M inistry of Local D evelopment began channelling resources to communities through the District D evelopment Fund. Prior to this the fund was channelled through line agency budget lines. In nominal terms, average annual block grant to local bodies is Rs. 2.5 billion, and absorption fluctuates with local-level implementation conditions.

The achievements in public expendituremanagement have resulted from the expansion and deepening of spending reforms. More reforms have been planned in the fourth year of MTEF implementation. 


\section{Box 4: Basic features of MTEF IV}

- Coverage extended to total budget and expenditurehas been classified into current and capital budget.

- Per unit cost of each major activity has been estimated and updated.

- Capacity-buildingand skill training for MTEF exercisesto bedone by all lineministries.

- Better prioritisation of programmes and projects.

- Programmebudgeting isrecommended for ensuring effectiveness of resourcesthrough better prioritisation, streamlining programmes/ projects and linking output with cost.

- Initiation of pro-poor and pro-gender budgeting, and.

- Induction of sectoral business plans - for linking the MDGs, PRSP and MTEF.

Besides ensuring predictability of funds to all priority projects, the funding guarantee to PRS outputs in selected sectors (education and health) are the hallmarks of MTEF achievement in 2004/ 05. The fourth M TEF (2005/ 062007/ 08) classifies the budget as current and capital and has also introduced the concept of gender and pro-poor budgeting. The government has also completed sectoral business plans for aligning resources to PRS outcomes through continued expenditure reforms. 


\section{Section V}

\section{Broad-Based Growth Performance}

\section{Agriculture}

The Agriculture Perspective Plan (A PP) (1995) is the core of the sector strategy. The APP envisages diversification and commercialisation of agriculture by raising cereal production in the Terai and the output of fruits, high value crops including N on-T imber Forest Products (NTFPs) and livestock in the $\mathrm{H}$ ill and Mountain regions. These are to be achieved by managing four key inputs: (i) controlled year-round irrigation, (ii) eased fertiliser supply, (iii) need-based research and extension, and (iv) linking potential production pockets with markets through rural agricultural roads and the expansion of rural electrification.

The PRSP renewed commitment to implement the APP. It embraces agriculture growth as the strategy for attaining broad-based growth. It has given highest priority to agriculture and rural development and has taken a comprehensive approach for easing constraints, by emphasising progressive private sector involvement in input and output marketing, strategic and coordinated provision of critical public infrastructure and services with stakeholder participation, partnership with privateprovidersincluding N GO s, and devolution of rural services.

A new institutional approach under the AgriculturePerspectivePlan Support Programme(A PPSP) istheD istrict Agricultural D evel opment Fund (D ADF) that isnow underway in 20 districts. Theselection of A PPSP implementation districts is based on the poverty and deprivation index. The DADF has two components, the District Extension Fund (DEF) and Local Initiatives F und (LIF).

The M inistry of Agriculture and Cooperatives (M O AC) implemented $32 \mathrm{P} 1$ and 10 P2 projects in 2004/ 05. Five P1 projects, the Agriculture/ Livestock Extension Programme, A PP M onitoring, APPSP, Crop Diversification Project and Small Irrigation Special Programmeshared 43 percent of the development budget of Rs. 2.52 billion allocated to the sector. 
Some other ongoing activities are:

- Implementation of N ational Agricultural Policy, 2004.

- Mobilisation of theprivatesector and N GO saspartner serviceproviders on a contract basis.

- Monitoring, quality control and regulation of inputssupplied by theprivate sector.

- Transfer of subsidies in the form of grants on goods and services.

- Devolution of extension services to local bodies.

- Transfer of veterinary services to the private sector on cost basis.

- Study for establishment of agriculture resource centres.

- Promotion of cooperatives and contract farming.

- Involvement of cooperativesin commercial milk and vegetableproduction and marketing.

- Development of market centres.

- Integration of irrigation and micro-irrigation with agricultural intensification for commercialising agriculture.

- Empowerment of women and disadvantaged groups through targeted programmes.

- Strengthening institutional capacity to meet theWTO requirements; and

- Implementing a special package programmefor the development of the Karnali Zone.

The MOAC has reviewed APP implementation and has formulated an Implementation Action Plan through the A PPSP. The basic objective of the review was to reorient the agricultural sector to create more responsive, productive and efficient services for therural poor. Agricultural sector policies need additional reforms to fulfil commitments made to global and regional institutions such as the WT $O$ and the South A sia Free Trade Area (SA FTA).

Table5.1 providesinformation on outcomes in thefood and agriculture sector in terms of intermediate indicators. There has been some increase in the expansion of infrastructures, mainly roads and electricity. H owever, there has been a decline in use of chemical fertilisers and improved seeds, and slow expansion in irrigation and agricultural credit. 


\begin{tabular}{|c|c|c|c|c|c|c|}
\hline \multirow{3}{*}{$\begin{array}{l}\text { Outcomel } \\
\text { Impact } \\
\text { indicators } \\
\text { Food security }\end{array}$} & \multirow{2}{*}{$\begin{array}{l}\text { Intermediate indicators } \\
\text { - N umber of districts served by } \\
\text { NFC }\end{array}$} & \multicolumn{2}{|c|}{ 2001/02 2002/03 } & \multirow{2}{*}{$\begin{array}{r}2003 / 04 \\
30\end{array}$} & \multicolumn{2}{|c|}{$\begin{array}{r}2004 / 05 \% \text { Change } \\
\text { over } \\
2003 / 04\end{array}$} \\
\hline & & 32 & 31 & & 30 & 0.0 \\
\hline & - Q uantity of food sold (tons.) & 8,213 & 5,693 & 6,100 & 5,882 & -3.6 \\
\hline \multirow{6}{*}{$\begin{array}{l}\text { Overall } \\
\text { agricultural } \\
\text { growth }\end{array}$} & - Length of rural roads $(\mathrm{km})$. & 2,361 & 905 & 840 & 934 & 11.2 \\
\hline & - N umber of VDC s electrified & 1,600 & 1,800 & 2,000 & 2,200 & 10.0 \\
\hline & $\begin{array}{l}\text { - Number of public market } \\
\text { collection centres/market yards }\end{array}$ & 31 & 33 & 750 & - & \\
\hline & $\begin{array}{l}\text { - Agricultural credit (ADB/ N } \\
\text { only - in Rs. million) }\end{array}$ & 7,110 & 7,669 & 10,151 & 10,432 & 2.8 \\
\hline & - Area under irrigation (ha.) & 937,722 & 985,546 & $1,128,000$ & - & \\
\hline & - U se of chemical fertiliser (tons.) & 193,154 & 172,270 & 161,316 & 157,077 & -2.6 \\
\hline \multirow[t]{4}{*}{ Crop production } & - N umber of functioning farmers groups & ps 7,508 & 9,383 & 11,272 & 13,118 & 16.4 \\
\hline & - U se of improved seeds (tons) & 2,654 & 2,574 & 5,751 & 2,824 & -50.9 \\
\hline & - N umber of pocket programmes & 1,897 & 1,967 & 1,967 & 2,509 & 27.5 \\
\hline & $\begin{array}{l}\text { - Crop/horticulture credit (Rs. } \\
\text { million) }\end{array}$ & 2,028 & 2,222 & 2,024 & 2,031 & 0.35 \\
\hline \multirow[t]{7}{*}{$\begin{array}{l}\text { Livestock } \\
\text { production }\end{array}$} & $\begin{array}{l}\text { - N umber of livestock farmers' } \\
\text { groups }\end{array}$ & 6,623 & 6,954 & 6,965 & 7,543 & 8.3 \\
\hline & $\begin{array}{l}\text { - N umber of artificially } \\
\text { inseminated livestock }\end{array}$ & 53,641 & 52,049 & 44,344 & 46,434 & 4.7 \\
\hline & - Production of milk (tons.) 1 , & $1,158,780$ & $1,195,931$ & $1,238,000$ & $1,274,000$ & 2.9 \\
\hline & - N umber of pocket programmes & 455 & 455 & 807 & 816 & 1.1 \\
\hline & $\begin{array}{l}\text { - Amount of livestock credit } \\
\text { (Rs. million) }\end{array}$ & 1,570 & 1,634 & 1,606 & 1,844 & 14.8 \\
\hline & - Production of meat (tons.) & 198,895 & 203,899 & 208,412 & 214,817 & 3.1 \\
\hline & - Production of eggs (000 number) & 538,420 & 557,361 & 575,565 & 590,137 & 2.5 \\
\hline
\end{tabular}

Source MOAC, 2005

\section{IRRIGATION}

Ir rigation is a key input for raising agricultural productivity and consequently household incomes and food security. Irrigation receives high priority in both the PRSP and APP. While about 43 percent of the countrys net cultivated area of 2.64 million hectares is said to have access to irrigation, most systems are of the run-of-theriver type and largely provide supplemental ir rigation. O nly about 40 percent of these systems are capable of providing limited year-round irrigation.

Ther eis considerable pressure on ir rigation systems resulting from structural and operational weaknesses while there is also an urgent need to increase 
agricultural growth through higher yields, cropping intensities and diversification to high valuecrops. Theproblems faced in theirrigation sector, especially in the public systems, are inadequate capacity of Water $U$ sers A ssociations (WUAs), below-capacity performance of systems (only twothirds of the total command area benefits from ir rigation and $40 \%$ has yearround irrigation), physical and technical deficiencies in irrigation systems, low-water use efficiency, poor operation and maintenance, negligible cost recovery (less than $5 \%$ ), inadequate maintenance funds (less than $50 \%$ in most cases), weak management, under-developed water-users' institutions, and low investment by the private sector (e.g. in conjunctive use of ground water, supplementary or non-conventional irrigation technologies).

The major objectives of the irrigation sector are to a) develop new ir rigation and drainageinfrastructures capable of providing controlledyear roundirrigation, b) attain sustainablemanagement of existing F armer M anaged Irrigation System (FM IS) and Agency Managed Irrigation Systems (A M IS), and c) support nonconventional irrigation to channel benefits to the poor. The irrigation policy (2003) seeks to empower Water U sers' A ssociations (WU As) to operate and manage their irrigation systems and to involve local bodies in the development and management of small and medium-sized systems. Strengthening theWU As by handing over small schemes or transfer ring management of key secondary canalsin thelarge/ medium irrigation schemesto user associationsor theprivate sector, will represent another major policy shift.

Theirrigation sector implemented $12 \mathrm{P} 1,12 \mathrm{P} 2$ and $1 \mathrm{P} 3$ projects in 2004/ 05 with a development budget of about Rs. 2.2 billion. The government is contemplating implementation of non-conventional schemes using microirrigation technologies, which are both pro-poor and pro-environment. For this, a separate unit - N ew Irrigation Technology Programme (N ITP) - has been established. The N ITP intends to irrigate an additional 10,000 ha. of land within the Tenth Plan period (starting 2005). A N ITP feasibility study has been completed. Some IN G O s had used non-conventional irrigation technologies in the past but their interventions were of a scattered nature.

TheA sian D evelopment Bank (ADB) has approved asix-year irrigation project that is to be implemented in 35 districts of the Eastern and Central regions. The first objective of the project is to improve agricultural productivity and sustainability of existing small and medium-size farmer managed irrigation systems that have low productivity and high incidence of poverty and to enhancethelivelihoods of poor men, women and excluded groups. Thesecond goal is to empower WUAs, improve irrigation facilities, expand agriculture 
extension and targeted livelihood programmes for the poor, women, Dalits and Janajatis.

The government is formulating another project, the Irrigation and Water Resources $M$ anagement Project. This project will be implemented with the support of the World Bank in 40 districts of the Western, M id-western and Far-western regions. It seeks to assist the improvement and modernisation of farmer-managed irrigation systems in the $\mathrm{H}$ ills, M ountains and the Terai. A nother project goal is to promoteground water ir rigation in theplains using proven technologies and approaches for tapping groundwater. It al so aims at improving services of public irrigation schemes in the Terai by transferring the management responsibility to WU As.

The performance of medium/large scale irrigation schemes has been mixed. However, ther ehas been improvement in groundwater ir rigation through shallow tubew ells. Six projects have supported theinstallation of 54,022 Shallow Tube wells(ST W s). Two among these, theC ommunity G round Water I rrigation Sector Project (CGISP) and the ST W programme of the Agriculture D evelopment Bank, arestill underway. G roundwater irrigation, mainly through STW $\mathrm{S}$, suffered a serious setback in the earlyyears of the PRSP implementation following the withdrawal of capital subsidy. The installation of ST W s has begun to pick up again. Thenumber of shallow tubewellsinstalled under theCG ISP hasincreased from 83 in 2000/ 01 to 2,257 in 2004/ 05 to a total of 4,589 thereafter. Besides, theproject has al so completed $87.2 \mathrm{~km}$. of road under its farm-to-market road improvement activity and work is underway on another $42 \mathrm{~km}$. STW installation has been increasing despite the withdrawal of subsidy.

A nother significant programmeistheSmall I rrigation and M arketing I nitiatives (SIMI) jointly promoted by Winrock International, International D evelopment Enterprises, SA PPRO S and CEA PRED in 2003 for providing integrated agricultural services. Irrigation is the entry-point in the SIM I, which aims to reach about 27,000 households in seven districts of the Western and M idWestern Development Regions.

\section{RURAL INFRASTRUCTURE}

The PRSP emphasises rural roads to link potential agricultural production pockets with markets and rural electrification for harnessing groundwater for year-round irrigation. A bout $934 \mathrm{~km}$. of roads have been built under therural infrastructure expansion programmes. There has been progress in the construction of the Jumla-Surkhet road as well as other key roads connecting 
K alikot, Jajarkot, Achham, Bajhang, Rukum and other mid- and far-western districts. Completion of these roads will bring significant gains in terms of access, which is vital for poverty reduction.

Road master plans have been prepared in 54 of the countrys 75 districts whilea 20-year road sector master plan is under preparation. Preliminary work for developing $N$ epal asatransit pointbetween Indiaand C hinahasbegun. Connecting district headquarters to the road network remains a government priority; 70 out of 75 district headquarters are to be connected by road by mid-2007. Six more districts are expected to be connected by roads by end-2006, against thetarget of 10 districts by 2007 . A total of $3,317 \mathrm{~km}$. of roads were built between 2003 and 2005 (638 km. strategic road and 2,679 km. rural roads). Thepace of road-building remains slow compared to the high demand and therefore, constructing roads to link areas with high agriculture potential remainsa priority.

\section{POWER}

The power sector is guided by the long-term vision (1997-2017), which emphasises pro-poor development by expanding power generation and distribution in rural areas. The sector had $18 \mathrm{P} 1,7 \mathrm{P} 2$ and 4 P3 projects in 2004/ 05 with a development budget of Rs. 5.5 billion.

The average per capita electricity consumption is only $68 \mathrm{KW} \mathrm{h}$ per annum. O nly 40 percent (37\% reported in N LSS II) of the population has access to electricity. The installed capacity of $555 \mathrm{M} \mathrm{W}$ is less than one percent of the total hydropower generation potential. A number of small hydro-plants are under construction but rural electrification remains a major issue because investors are reluctant to invest in the rural areas.

The Tenth Plan intends to develop and expand alternativeenergy in rural areas and reduce dependency on imported energy. Expanding the grid to rural areas requires high investment and ther efore, the focus is on alternative energy.

\section{FORESTRY}

A Imost 39.6 percent of thetotal land area of $\mathrm{N}$ epal is under vegetation cover. A though over 10 percent of this is scrubland, succesful community and leasehold forestry programmes have hel ped regenerate forests. Some achievements in the for estry sector are:

- TheCommunity Forestry D evelopment Programmehasbenefited about 
onethird of all households of $\mathrm{N}$ epal by increasing their accessto forest resources, such as fodder and firewood. Theprogrammehasalso helped increase women's participation in user committees.

- The Leasehold Forestry Programme being implemented in 26 hill districts aims at reaching out to landless families and has proven to be an effective means to reduce poverty. It has contributed towards improving the incomes of very poor families while also helping to restoreenvironmental heal th. 0 ver 2,120 leasehold for estry groups have been formed and 227 action plans have been prepared.

- All community forestry programmes in the hill and mountain districts (especially community and leasehold forests) have been effective in increasing women's participation, raising access to forest resources for houschold use, and for conserving theenvironment and generatingincome.

- Thearea under community forests has increased from 1,062,823 ha. in 2002/ 03 to 1,170,896 ha. in 2004/ 05 (T able 5.2).

- The successful conservation programmes have helped to slowdown degradation of land and forests. The area under conservation has al so been expanded through involvement and participation of peopleliving in the buffer zones.

\begin{tabular}{|c|c|c|c|c|c|}
\hline $\begin{array}{l}\text { Outcome/ } \\
\text { Impact indicators }\end{array}$ & Intermediate indicators & $2001 / 02$ & $2002 / 03$ & 2003/ 04 & 2004/ 05 \\
\hline \multirow[t]{5}{*}{$\begin{array}{l}\text { A rea under intense } \\
\text { forest coverage }\end{array}$} & $\begin{array}{l}\text { Area under community } \\
\text { forest (ha.) }\end{array}$ & $1,028,473$ & $1,062,823$ & - & $1,170,896$ \\
\hline & $\begin{array}{l}\text { A rea under leasehold forest } \\
\text { (ha.) }\end{array}$ & 4,378 & 7,061 & - & 9,838 \\
\hline & $\begin{array}{l}N \text { umber of households under } \\
\text { leasehold forest }\end{array}$ & 9,070 & 10,027 & 11,253 & 15,122 \\
\hline & $\begin{array}{l}\text { A rea under national parks/ } \\
\text { protected area including } \\
\text { buffer zone (\% of total land) }\end{array}$ & 18.0 & 18.3 & 18.3 & 19.7 \\
\hline & $\begin{array}{l}\text { Area under forest cover, } \\
\text { including shrub land (\%) }\end{array}$ & 39.6 & 39.6 & 39.6 & 39.6 \\
\hline $\begin{array}{l}\text { Income from } \\
\text { forestry }\end{array}$ & $\begin{array}{l}\text { Income generated by FUGs } \\
\text { (CFU Gsonly; Rs. in million) }\end{array}$ & 129 & 124 & - & NA \\
\hline
\end{tabular}

A recent evaluation of the H illsLeasehold Forestry and Forage D evelopment Project (H LFFDP) suggests that the programme has been able to reduce poverty and empower low income, landless groups (Box 5). The H LFFDP began in four pilot districts in 1994 and was extended to 26 districts by end2000. The impact evaluation was carried out in 10 of the 26 districts. 


\section{Box 5: Environmental and economic impact of leasehold forestry}

The followings are some findings of the evaluation of leasehold forestry in 10 districts:

- Agriculturewasthemain occupation of only $45 \%$ households. Excludingwheat, productivity of all major crops had decreased over theyears.

- Altogether, $88 \%$ users areengaged in group saving and credit programmes, of which $43 \%$ areinvolved in mobilising funds.

- A mong the leasehold forestry households, cash income from agriculture has decreased, whilethat from livestock hasal most doubled. Theshare of livestock products, remittance and wage earning in the average household income was $26 \%, 24 \%$ and $23 \%$, respectively.

- Thenumber of ruminant livestock has decreased but milk production increased indicating a declinein unproductive cattle.

- Theexpenditurepattern of leasehold householdshasalso changed. Theproportion of household spending on food decreased to 91\%. Likewise, spendingon education, health and clothingincreased by $78 \%, 90 \%$, and $99 \%$ respectively compar ed to $5 \%, 2 \%$ and $7 \%$ during the baseyear.

- Leasehold forestry hashelped to improvethelivingstandards of $30 \%$ poor farmers. It has al so hel ped to build a foundation for further enhancement of their economic statusthrough improved grass production, plantation of N TFPs, social empower ment, skill development, and improved breeds of livestock. G enerally, households that received better-quality land on lease have had quicker benefits.

- There has been improvement in thecrown cover and composition of for ests. A Imost 50\% of land that had no vegetation is now covered by trees and shrubs. A total of 1,956 patches of forestshavebeen raised on 8,037 ha. under theprogramme, compared to $569 \mathrm{ha}$. of land in the base year (1997). O $\mathrm{n}$ average, there are 644 plants per ha. of leased land. Leasehold for ests haveincreased greenery becausegrazing has been controlled. The promotion of the "cut-and-carry" fodder collection method has also helped to reduce erosion.

- The control of grazing has allowed natural regener ation and thevegetation has al so been augmented through new plantation. M ore than $95 \%$ households involved in the project and control groups practice stall-feeding with less than one month of free grazing.

- Thereisnot much changein theuse of improved cooking stoves compared to the baseline value(18\%). Theonly district wheretherew as significant increase is R amechhap whereits use had grown by $44 \%$.

- Group formation and forest handover processes, however, have not fully complied with the project operational guidelines. The programme has al so had to face different types of conflicts. Themajor disputes relateto exclusion of thepoor and marginalised groups, lack of clear demarcation of forest and privateland and confusions relating from the overlap of community and leaseholds forests in some districts. H owever, inclusion of poor and marginalised households has been improving. The proportion of targeted populations (poor and marginalised households) in new groups is higher than that in old groups.

- Tamangs comprise $26 \%$ of the population in leasehold FU Gs, Magar (12\%) and N ewar (11\%). Besides, other indigenous nationalities such as the Praja, Dara, H ayu, Kumal and Thami haveal so benefited. But thenumber of peoplefrom thesegroupsin theFU Gsislow. The proportion of Brahmin and Chhetri in leasehold FU Gsare $10 \%$ and $12 \%$, respectively.

- The land leased to landless and "ultra" poor households was of poorer quality than that provided to other groups.

- Overall, theparticipation of men and women in leasehold forestry management is similar. However, women's participation in har vesting of for est productswas higher though they had less control in selling forest products and using theincome.

- A third of the leasehold FU G s were functioning well, and

- Literacy rate in the project has increased from $38 \%$ in 1995 to $69 \%$ in 2004/ 05; with male literacy at $77 \%$ and female liter acy at $60 \%$. The literacy rates are higher than the national average.

Source: NPC, $2005_{d}$ 


\section{PrOMOTING NON-AGRICULTURAL GROWTH}

Thenon-agriculture sector, which contributes about 60 percent of Gross Domestic Product (GDP), playsan important role in accelerating and sustaining theoverall PRSP growth targets. TheTenth Plan emphasises continuation of transparent, simpleand private sector-friendly economic policiesin order to createa supporting environment for

\section{Box 6: Private sector development initiatives}

- Labour O rdinance

- Secured TransactionsO rdinance

- SecuritiesO rdinance

- Company O rdinance

- Liquidation, M erger and Bankruptcy Ordinance

- Implementation of accounting and auditing standards

- Simplification of tradeand investment procedures (on-going), and

- A mendment of theForeign Investment Act (ongoing).

non-agriculture sector growth. The actions have focused on overall policy reform, including reforming the financial sector and other private sector development initiatives (Box 6).

Activities in the non-agriculture sector are mostly led by the private sector. However, the government still dominates some key areas such as, electricity, telecommunications, and drinking water and, to some extent the financial sector. N on-agricultural growth remains adversely affected by political instability and weak external and domestic demands. The slowdown in development activities- and other economic activities, in general - has caused domestic demand to fall sharply. Thegovernment has taken steps to enhance industrial security and has introduced new policies - including the Build$O$ perate $O$ wn and Transfer (BO OT) - for raising private sector participation in infrastructure building. The government has also further opened up the skies to allow moreairlines to fly in and out of $\mathrm{N}$ epal. A ccounting standards and the regulatory environment have been improved for enhancing the efficiency of public enterprises.

\section{Public ENTERPRISES REFORM AND PRIVATISATION}

Nepal has taken major steps to dismantle public sector monopolies and inefficient public enterprises. The reforms in the telecommunications sector have been themost far-reaching. TheN epal Telecommunication Corporation was converted into a public company in A pril 2004. A joint venture private operator has been allowed to provide basic tel ephone services in K athmandu and another privateoperator has been selected to providetelecommunication 
services in 534 V D C sin theEastern region. A private operator has al so been permitted to provide mobile telephone services.

The government has announced a policy to involve the private sector in construction and operation of small and medium scale hydro-electricity projects. Such projects would besupported through the Power D evelopment Fund, established in 2003. Also being implemented is a policy to involve communities and cooperatives in electricity distribution in rural areas. The $\mathrm{N}$ epal Electricity Authority has begun distributing electricity to rural communities through arrangements made under the policy. $\mathrm{N}$ epal has approved a policy for involving theprivatesector in theimport and distribution of petroleum products. Arrangements are also being finalised for handing over operations of the $\mathrm{N}$ epal Water Supply Corporation in K athmandu to a private operator.

The public enterprise reform process was revitalised during the early years of PRSP implementation. A number of enterprises have been identified for privatisation, leasing, liquidation, transformation into public companies, and for introducing perfor mance contracts. By 2003, about 23 public enterprises were privatised or liquidated. TheBhaktapur Brick Factory was leased out in 2004.

A $n$ assessment of the assets and liabilities of the Royal $\mathrm{N}$ epal Airlines Corporation is underway, with a view to transform it into a public company. Besides, performancecontracts havebeen introduced to improvemanagement at some public enterprises, including two large cement factories at $U$ dayapur and $\mathrm{H}$ etauda. The government has been focussing on updating the audit of public enterprises prior to privatisation. Theaccounts of 24 public enterprises were audited in 2003/ 04.

\section{FINANCIAL SECTOR REFORM}

Since late 1990s, N epal hasbeen implementinga comprehensivefinancial sector reform programme with the assistance of the World Bank. The objective is to improvethefinancial posi-

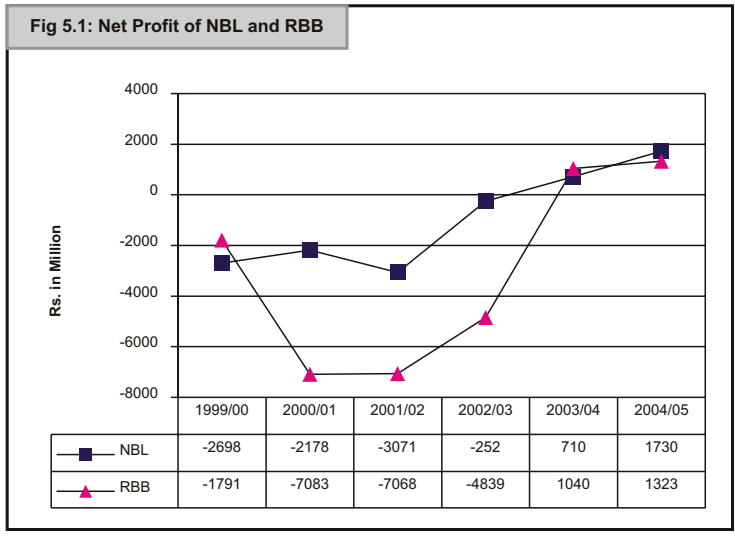




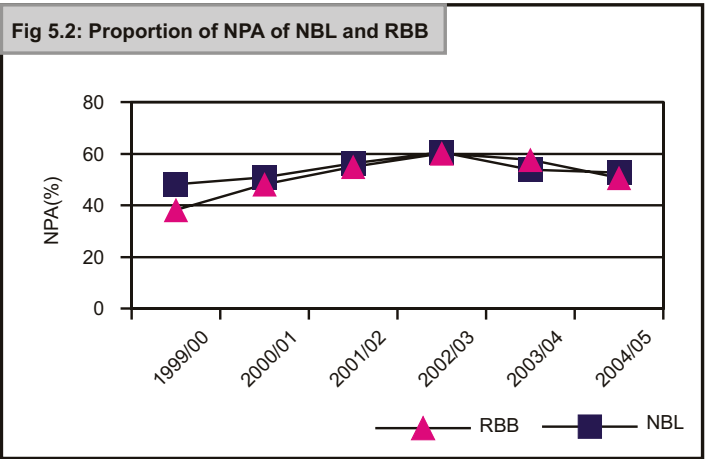

tion of the two problematic state-controlled banks, improve accounting and auditing standards, strengthen monitoring and regulatory capacity of the $\mathrm{N}$ epal Rastra Bank (N RB) (central bank), strengthen legislative and institutional framework and restructureand privatise state owned-banks. Besides, it also includes restructuring of the publicly owned N epal Industrial Development Corporation and Agriculture D evelopment Bank, both of which are facing serious financial problems.

A ctions are underway to reengineer and restructure the $N \mathrm{RB}$ to enhance its capacity for regulating and supervising the financial sector. A new organisational framework hasbeen introduced at thecentral bank; staff number has been reduced (571 staffs have been reduced voluntary retirement and 11 under the compulsory retirement scheme). Moreover, in order to improvethe skills and efficiency, 30 staffs have been offered on-the-job training and 46 external auditors havebeen trained; a publicrelation officer has been appointed; information technology has been modernised; and the infor mation system has been strengthened using new software and hardware. A new audit and accounting framework has been introduced and the overall capacity of N RB for supervision and regulation has been enhanced. A new law has also been enacted.

A comprehensiveprogrammeisunderway to revamp two stateowned commercial banks - R astriya Banijya Bank (RBB) and N epal Bank Limited (N BL) (partially owned) - by lowering their non-performing assets (N PA) to acceptable levels, streamlining staff and injecting modern management techniques. As per the programme, international consultants werehired to manage RBB and N BL, and a series of measures have been taken to improve their performance. The banks have launched intensive debt recovery programmes, where they have had some success. H owever, theN PA levelsstill remain very high even though cash recovery from bad loans has exceeded Rs. 12 billion.

The N BL has come a long way since 1999/ 2000 when its net loss was Rs. 2,698 million to a profit Rs. 1,730 million in 2004/ 05. Similarly, R BB has al so improved its finances, from a net loss of Rs. 1,791 million to a profit of Rs. 


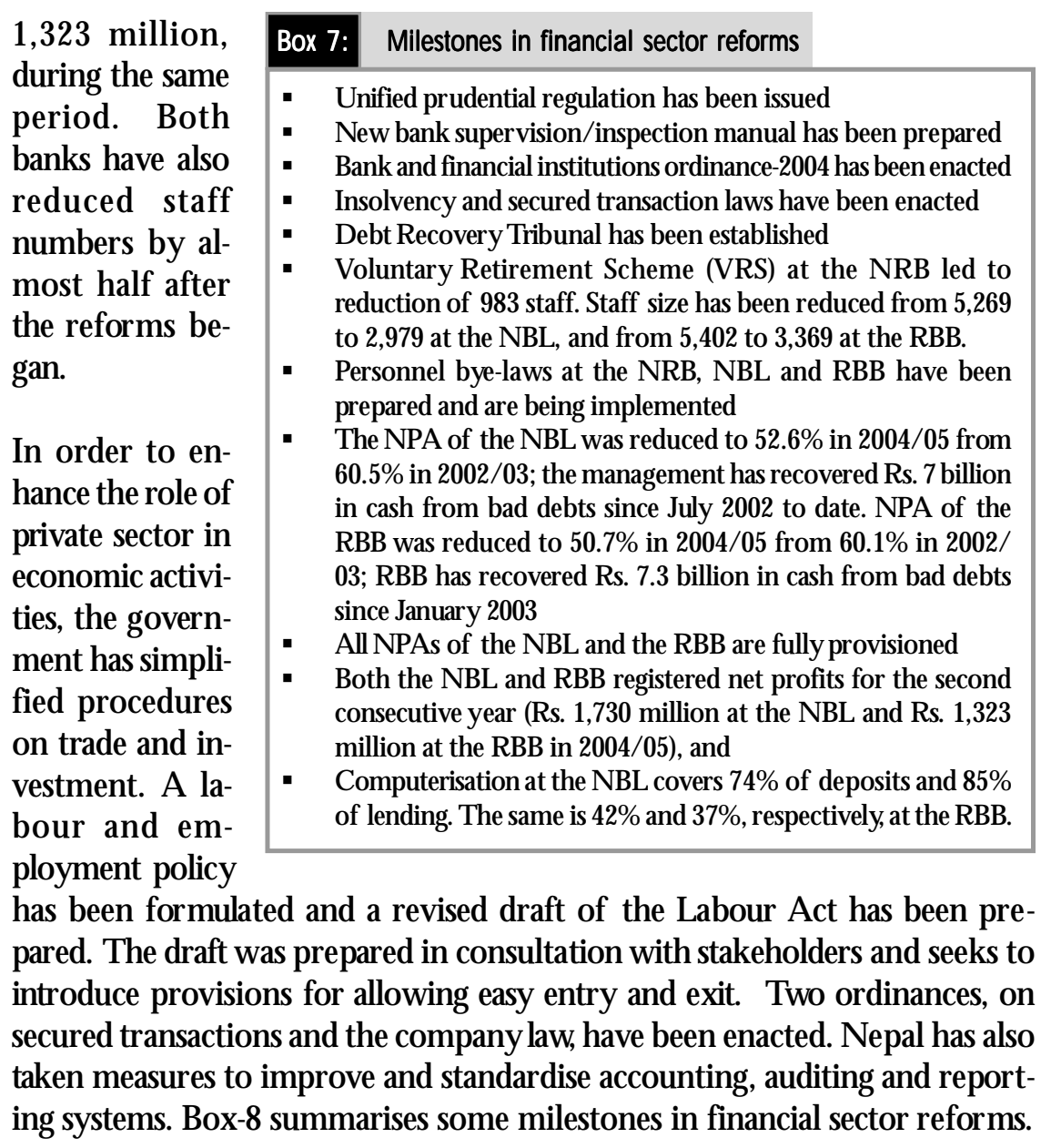




\section{Section VI}

\section{Social Sector}

\section{EDUCATION}

The education sector has performed reasonably well despite the conflict. H owever, the displacement of school children still remains an issue. Student enrolment in primary education has increased; the access of disadvantaged children to primary education hasimproved; and theprimary cyclecompletion rate has increased. Some of these improvements have resulted from new measures to enrol and retain more children from disadvantaged communities in schools.

Enrol ment: In order to extend primary education coverage, the government has launched an enrolment campaign (Welcome to School Initiative) aimed at attracting out-of-school children. The government believes that enrolment cannot be increased without reaching out to children of poor and disadvantaged communities. The Welcome to School Initiative (2005) has been effective in motivating the targeted communities to send children to school. Theprogrammehas been more effectivein communitieswhereN GO s and local leaders participated in the campaign. Two other programmes, the school outreach (for 6-8year-olds) and flexibleschooling (for 8-12 year-olds) aim at providing learning opportunities to out-of-school children by bringing them into thesystem. These programmes have been targeted with good effect among special groupsand/ or areas. The effortsto increase access to education and retain students are supported by scholarships and school feeding (midday meals) schemes. ${ }^{1}$

Thegovernment has recruited more femaleteachers (share of femaleteachers in primary schools is 30\%) and supported construction of separate latrines for girls (now 11,341 schools have separate latrines) to make the school environment more friendly for female students. All of these efforts haveled to encouraging results: net primary enrolment ratehas reached 86-87 percent

\footnotetext{
${ }^{1}$ Processmonitoring of freetextbook and scholarship programmes has, however, pointed out deficiencies including under funding, delayed availability, or unavailability (For details refer to Process M onitoring of Targeted Programmes F ree Textbook Distribution and $\mathrm{N}$ ational Scholarship Programmes of D oti and Banke Districts, D evelopment Vision N epal, 2004).
} 
(88\% was thetarget of 2005/06), only two percent short of PRStarget. ${ }^{2}$ The enrolment of girlshasincreased ${ }^{3}$, and so has that of children from the "low" castes and disadvantaged ethnic groups. Children of former bonded labourers (Kamaiya) have also enrolled in notable numbers. The challenge now is to retain and enable them to complete the schooling cycle.

Some new initiatives were launched and many ongoing activities were scaled up for improving education efficiency. Teacher training packages werereviewed and revised and thefacility was expanded to anetwork of 34 education training centres, 100 private primary teacher training centres and 80 alternative providers. A n additional 10,720 teachers were trained in 2004/ 05 and in July 2005, therewere 30,967 trained primary teachers (around 31\%). A ccording to theE conomic Survey 2005, primary school teacherscompletingall four training packages numbered 14,992 . The process of certifying teachers is almost complete and the continuous assessment system has been introduced in five districts. Theprivate sector wasinvolved in the distribution of freetextbooks in five districts - on a pilot basis - for improving delivery.

The targeted scholarship programme has been expanded to children from disadvantaged communities (some 560,000 children form "low" castes and 635,380 girls received primary school scholarships in 2004/ 05). Additionally, the Early Childhood Development Centres, run by the government and I/ NGOs, prepared more children for formal schooling.

Overall, the primary cycle completion rate improved from 50.4 percent in 2003/ 04 to 68 percent in 2004/05. The percentage of students completing the primary level also rose by nine percentage points in 2004/05. D espite these improvements, the quality of education remains a problem.

Schools transfer: A $n$ important initiative underway is the transfer of school management to communities for changing the way public schools have been run. Relevant provisions of the Education A ct have been amended to enable School Management Committees (SM Cs) - comprising of parents, teachers and village education committeemembers- to recruit teacherslocally. D espite the "teething" problems and inadequate monitoring, the arrangement has enhanced local ownership of education.

${ }^{2}$ N LSS 2003/04, however, estimates net enrolment rate at the primary level at 72 percent.

${ }^{3}$ This is encouraging and desirable considering that 42 districts in ter ms of Gross Enrolment R ate (GER) and 50 districtsin terms of $\mathrm{N} E R$ havegender parity index (GPI) below 0.97 , indicating gender imbalance (G PI data from BPEP II and Education for All, Status Report 2004, D epartment of Education). 
The ongoing programme to decentralise school management can help to enhance education quality through close supervision and management of teachers and teaching processes by the beneficiaries. H owever, thereare some unresolved issues about the status of teachers at such schools; another issue is assuring communities of long-term government support. The programme slowed down in 2004/ 05 owing to a number of factors, including thepolitical uncertainty. G overnment support to community-managed schools- financial (including resourcemobilisation) and pedagogic - needs to ber esolved before restarting the school transfer programme. Continued public investment in education - which is a PRS priority - can help N epal attain the education targets of the Tenth Plan.

A dult literacy: A dult literacy (15 years and above) - another PRS focus was 48 percent in mid-2004 (N LSS 2003/ 04). This increased to 55 percent in 2005. H owever, the average masks the wide variations in literacy rates among various social groups and geographical regions. Female eliteracy, for example, is only 33.8 percent; the literacy of the poorest quintile is 23.1 percent and that for the eastern rural plains is 36.5 percent.

The government expanded the adult literacy campaign significantly in 2004/ 05 by involving $\mathrm{N} \mathrm{GO} \mathrm{s/CBO} \mathrm{s} \mathrm{and} \mathrm{local} \mathrm{bodies} \mathrm{in} \mathrm{delivery.} \mathrm{There} \mathrm{are} 50$ community learning centres providing adult literacy coaching, and some 702,470 people completed adult literacy classes provided under the government'sprogrammesin J uly 2005. Thisnumber included 183,000 females (T able 6.1). Additionally, some 4,401 neo-liter ates participated in post-literacy income generating programmes. In order to make education relevant, the new literates are trained on life skills and introduced to CBO-led income generating schemes.

Technical training: In 2004/ 05 the Council for Technical Education and Vocational Training (CTEVT) provided short-term training to 2,309, longterm training to 2,097 and basic skill training to 1,221 persons. It also trained another 11,637 persons under the community service programme. The government has been encouraging private sector involvement in both basic and middle-level skill training, but has yet to begin the voucher system to target training to poor and disadvantaged groups. 


\section{Table 6.1: Major achievements in education}

\begin{tabular}{lrrrrr}
\hline Indicators & \multicolumn{3}{c}{ Fiscal year } & & $\begin{array}{r}\text { \% Change } \\
\text { over }\end{array}$ \\
& $2001 / 02$ & $2002 / 03$ & $2003 / 04$ & $2004 / 05$ & $2003 / 04$ \\
N umber of primary schools & 25,194 & 26,638 & 26,858 & 26,277 & -2.16 \\
N et enrolment rate of primary school & 81.1 & 82.4 & 84 & 87 & 4.76 \\
N umber of certified teachers & $\mathrm{NA}$ & 27,875 & 120,988 & $\mathrm{NA}$ & - \\
Pupils completing primary education (\%) & 60 & 67.7 & 69 & 78 & 13.04 \\
$\begin{array}{l}\text { Primary cycle completion (\%) } \\
\text { Primary teachers trained (\%) }\end{array}$ & $\mathrm{NA}$ & & 50.4 & 68 & 34.92 \\
N umber of girls in primary schools & 15 & 15 & 31 & 35 & 12.9 \\
receiving scholarship & 151,568 & 120,742 & 224,656 & 635,380 & 182.82 \\
Share of female teachers in primary & 21.4 & 22.1 & 21.1 & 30 & 42.18 \\
schools (\%) & & & & & \\
N umber of community learning centres & 20 & 40 & 52 & 51 & -1.92 \\
N umber of female completing adult & 23,942 & 26.733 & 39,262 & 183,000 & 366.09 \\
education & & & & & \\
Schools with latrines for girls & 7,613 & 9,741 & 10,633 & 11,341 & 6.65 \\
N umber of schools transfer red to & - & 90 & 1,500 & 2,091 & 39.4 \\
local communities & & & & & \\
\hline
\end{tabular}

Source: MOES, 2005

\section{Table 6.2: Budgetary performance of the education sector}

\begin{tabular}{|c|c|c|c|c|}
\hline Indicators & $\begin{array}{r}2002 / 03 \\
\text { Actual } \\
\text { Expenditure }\end{array}$ & $\begin{array}{c}2003 / 04 \\
\text { Actual } \\
\text { Expenditure }\end{array}$ & $\begin{array}{r}2004 / 05 \\
\text { Revised } \\
\text { Expenditure }\end{array}$ & $2005 / 06$ \\
\hline Expenditure on education ${ }^{5}$ & $13,286,606$ & $14,477,740$ & $16,190,616$ & $21,250,447$ \\
\hline Year-on-year change & 1.1 & 9.0 & 11.8 & 31.2 \\
\hline Education expenditure as $\%$ of total expenditure & 15.8 & 16.2 & 16.0 & 16.7 \\
\hline Education expenditure as $\%$ of education budget & 92.2 & 92.7 & 89.6 & 100.0 \\
\hline Expenditurein prir & $7,841,007$ & $8,507,380$ & $9,101,293$ & $12,317,099$ \\
\hline Annual changein primary education expenditure (\%) & 12.2 & 8.5 & 7.0 & 35.3 \\
\hline $\begin{array}{l}\text { Share of primary education in total education } \\
\text { expenditure (\%) }\end{array}$ & 59.0 & 58.8 & 56.2 & 63.0 \\
\hline Expenditure on free textbooks ${ }^{6}$ & 122,688 & 265,014 & - & \\
\hline Annual change in expenditure on free textbooks (\%) & 32.6 & 116.0 & - & \\
\hline $\begin{array}{l}\text { Expenditure on Food for Education programme } \\
\text { (primary school) }\end{array}$ & 318,413 & 380,901 & 534,552 & 776,216 \\
\hline $\begin{array}{l}\text { Annual change in expenditure on Food for Education } \\
\text { programme }\end{array}$ & -0.7 & 19.6 & 40.3 & 45.2 \\
\hline $\begin{array}{l}\text { Expenditure on school transfer and incentive } \\
\text { programme }\end{array}$ & - & 109,487 & 98,351 & 150,000 \\
\hline Annual change in expenditure on school transfer & & & -10.2 & 52.5 \\
\hline
\end{tabular}

Source MOF, 2005a

${ }^{4}$ Thenumber of schoolsreported in 2004/ 05 is less than that of previousyear, which could bedueto the merger of schools and/ or reporting based on the progress report sent by the schools and not a nationwide survey.

${ }^{5}$ Spending by the Ministry of Education and Sports only

${ }^{6}$ This expenditure item included under Education For All programme since 2004/ 05. 
Expenditure: In terms of spending, the education sector accounted for 16 percent of total budget allocation and around 20 percent of total allocation during 2002/ 03-2004/05. Education expenditure has grown from 1.1 percent in 2002/ 03 to 11.8 percent in 2004/ 05 (Table 6.2). A lmost 90 percent of education expenditure is recur rent. The projected spending on primary education was about 58 percent and actual spending, was about 63 percent. Within primary education, spending on school feeding, free textbook distribution and scholarship programmes rose significantly (the latter two budget heads are now under the "Education for All" programme). In the 2005/ 06 of 36 projects/ programmes under the education ministry, 18 have been accorded highest priority (P1) and oneisunder the "targeted programme" category.

Overall, therehas been progress on somekey indicators of primary education but the achievement in adult literacy falls far short of the PRS target. The adult literacy target (63\%) and female literacy target $(55 \%)$ are too wide to be bridged during the remaining years of the PRSP.

In primary education, though current performance assessment is based on official figures drawn from the poverty monitoring database, there are discrepancies in the net primary enrolment rate reported by N LSS 2003/ 04 and the official data. Thedifferenceissignificant and beyond nor mal sampling errors. O ne explanation for the discrepancy is that many children are "technically" enrolled but not all of them attend school regularly.

ThePR Senvisages thetransfer of at least 6,000 schoolsto local communities. Schools transfer red to communities are provided an annual grant equivalent to the salary of two teachers plus a lump sum amount of Rs.100,000. They areal so entitled to receivegovernment scholarships. Progress in the first three years of PRS implementation is only 35 percent. Of particular concern is a sharp drop in thetransfer rate, down from 1,410 schools in 2003/ 04 to 591 in 2004/ 05.

Major issues: Demand side constraints slowed down the transfer process whileuneven implementation, the conflict and thelack of inputsand process monitoring, also contributed to the slowdown. There has also been some resistance to the transfer from interest groups (e.g. teachers) and there are concernsthat transfer ring ownership could underminetheaccess of children from disadvantaged groups. The concerns are not unfounded because even now children from under privileged groups are denied access even to "free" primary schooling becausetherearehidden costs (and al so opportunity costs). 
There is al so the general perception that the government istrying to absolve itself from responsibility by transferring the schools to community management, which is why many communities are unwilling to take on the management responsibility. The technical capacity of the SM Cs is also an issue. The government, ther efore, needs to remain aware about the coercive tactics of different interest groupsand to find waysfor supporting communities in their endeavours. R aising the participation of Women, $D$ alit and Janajatis in the SM C s and Parent Teacher' A ssociations (PTA) are equally important. The other challenge is assisting the SM C s to mobilise local bodies support.

Education has al so been affected by theconflict. A lthough number of schools that have been forced to shut down is small, of concern is the number of days the schools have been forced to shut down. Estimates suggest that some schools lost as many as 40-50 of the 200 days in the calendar in 2004/ 05. D espite problems, the school system remains more or less intact and is still functioning.

Theeducation of displaced children remainsan issue, however. A largenumber of students have been displaced from the conflict-affected areas and more are being forced to move every year. M ost of the displaced children are in 11-15 years age group and most of them have either completed primary schooling or were in the process of completing the level when they were forced to move. These children (not all of them arefrom poor families) have been deprived of education. Some displaced children rejoin schools in areas where their families settle but this has caused overcrowding of some public schools. M any students have also discontinued study for other reasons such as conflict-induced trauma, families unable to afford readmission to schools, and administrative difficulties (because they lack proper documents needed for admission).

In 2005, the D epartment of Education instructed schools to admit children even if they did not produce transfer certificates (which could be provided at a later date). H owever, the issues of trauma and theinability to pay need to be addressed separately. The issue of redeploying teachers from schools where students havemigrated al so needs to be resolved. Thefollowing areareas that need further improvements:

- Continuethesuccessful Welcometo School Initiativeand thenon-formal education programmes with additional efficiency enhancing measures. A longside the primary school feeding programme, targeted scholarships need to be expanded together with the increase in enrolment. There is 
also need for expanding the classrooms and increasing the number of teachers in order to be able to retain students.

- Consider scaling-up private-sector involvement in textbook printing and distribution after refining the modality based on the pilot experience. Enhancing such a programme is important because more and more children from poor and disadvantaged groups have begun to enrol in primary education.

- Ensure greater focus on implementing measures to support bilingual education. Translating, printing, identifying target ar eas and groups and distribution of textbooksare the major tasks that need to be car ried out.

- Launch VDC-wise literacy campaigns using local N GO s in partnership with local bodies(when fully reactivated). Extend programmesto increase relevance of literacy activities by providing lifeskillsand linking up literates with incomegenerating activities.

- Prepare and empower local communities to assume responsibility for managing schools using successful examples as models to convince the sceptics. Meeting all government commitments and assurances under thetransfer agreement is very important for confidencebuilding. Properly managed and implemented, the school transfer programme could be an appropriatepolicy response for ensuring smooth functioning of schools even during the difficult times.

- Introduce process monitoring to assess the access of disadvantaged children, the functioning of SM Cs and parent involvement. Consider linking transferred schools to local bodies for monitoring, guidance and support (e.g. administering school improvement plan or performancebased incentive plan), without undermining their autonomy, as part of decentralising the responsibility for primary education to local bodies.

- Implement a special package for assisting schooling of the displaced children. Proactive efforts are needed for integrating displaced students into the education system (the action should include tracing displaced children, counselling them and assisting them to rejoin schools).

- Strengthen monitoring and database management to meet the requirements of the sector-wide planning and management approach adopted in education. Investigatethediscrepancy in net primary enrolment rates between N LSS 2003/ 04 and official estimates and finalise the database. 
- Institutional ise the benefit data validation system on the implementation of different targeted programmes like the national scholarships for girls and children from disadvantaged groups.

\section{HEALTH}

There has been progress in the health sector but the basic indicators still remain poor. Inadequate access of the disadvantaged, the poor and people from remote areas to essential health care services remains a major problem. Further, infectious, maternal and prenatal diseases remain a major cause of mortality and morbidity. The occurrence of non-communicable diseases has also been growing steadily, particularly in urban areas. The government has yet to find an alternative mechanism for financing and expanding secondary and tertiary healthcare in order to be able to redirect funding for preventive and basic healthcare. $\mathrm{N}$ epal still lacks appropriate policy instruments and institutional capacity for adding value and aligning health spending with outcomes.

D espiteincreasing use of contraceptives and other family planning measures, the population has continued to grow at an unsustainably high level. A ssured publichealth expenditure(in theface of growingdemand), funding of essential recurrent expenditures, provisioning of adequate medicines and equipment in remote areas, retention of health technicians, performance and quality of service delivery, and affordability of rising health costs are other challenges facing the sector.

Strategies: The health sector has made efforts in strategy, policy and plan formulation and information management. $\mathrm{N}$ epal has sector and sub-sector strategies and implementation plans, policies for specific programme areas, and directives and guidelines for key operations. A mong recent actions, the heal th sector strategy for mulated in 2004 lays down an agendafor refor m; the National N eonatal Strategy and Vulnerable Community Development Plan and $\mathrm{H}$ ealth CareWasteM anagement plan were developed in 2004; theN utrition Strategy was formulated in 2005; and the Skilled Birth A ttendance Policy was drafted in 2005. H owever, N epal still lacks policy and strategic modalities for, a) public-private partnership, and b) a policy for decentral ising health service management with a strategic roads map specifying actions to devolve and those to bemanaged by central agencies except for handing over a few health facilitiesto communitiesfor management in order to improve ser vicedelivery. 
A sector-wideapproach has been adopted in planning, programming, funding, monitoring (performance review) and delivering health care services. There are still major gaps in matters of aid har monisation and transparency in aid flows for health services. H owever, sector wide programme in conjunction with MTEF framework resulted in increased budget allocation to the health sector in 2005/ 06. A practice of joint biannual reviews- onefor health sector performanceagainst thebackground of agreed policy reform milestones and output indicators, and another on the outputs-based work programme and budgeting - has been initiated. Two donors have been pooling resources from 2004/ 05, following the adoption of the sector-wide approach and the $\mathrm{N}$ epal $\mathrm{H}$ ealth Sector Programme.

Four of eight inter mediatehealth indicators revealed lower progress in 2004/ 05 compared to 2003/ 04 (Table 6.3). Immunisation coverage has dropped significantly while there has been progress in measures to control malaria, $\mathrm{K}$ al a-azar, tuber culosis and leprosy. A summary of major health programmes and achievement of the health sector is given in Annex 6.1.

I mplementation issues: Some difficulties encountered during programme implementation are (i) unavailability of essential drugs, vaccines and supplies due to delay in procurement and disruption of the distribution system, (ii) difficulty in assigning technical staff in remote locations and their retention, (iii) problemsrelated to repair and maintenance of equipment and other health infrastructures (also in assessing the standard of equipment and medicines), (iv) weak coordination and cooper ation with and among donorsand I/ N GO s, (v) inadequate capacity of local institutions to manage health facilities, and (vi) insufficient monitoring and backstopping at different levels. Given the cur rent health status ${ }^{7}$ greater effortsand investment are needed for achieving thesector targets. ThePRShealth targetsincludedecreasing theinfant mortality rate from 64 to 45 per 1,000 live births, child mortality rate from 91 to 72 , maternal mortality rate from 415 to 300 (per 100,000 births), and raising life expectancy from 61.9 to 65 years.

\footnotetext{
Selected national level health indicators are: infant mortality rate 61 (N epal M DG Progress R eport, 2005), U 5 M R 82 (N epal M D G Progress Report, 2005), maternal mortality rate 740 (2000, H DR 2005) and life expectancy 61.3 years (2003, H DR 2005).
} 


\begin{tabular}{|c|c|c|c|c|c|}
\hline \multirow[t]{2}{*}{ Indicators } & \multicolumn{3}{|c|}{ Fiscal year } & \multicolumn{2}{|c|}{ \% Change } \\
\hline & $2001 / 02$ & $2002 / 03$ & 2003/04 & 2004/05 & $2003 / 04$ \\
\hline Women receiving ANC $1 \$$ t visit & - & 53 & 66 & 69 & 4.5 \\
\hline Women receiving at least 4 A N C visits (\%) & 37.9 & 36.8 & 43.6 & 44.1 & \\
\hline Women receiving adequate PN C visits (\%) & 14.4 & 18.8 & 28.3 & 30.4 & 7.4 \\
\hline Births by skilled attendants (\%) & 15.0 & 16.1 & 18.0 & 20.2 & 12.2 \\
\hline Malnourished women (\%) & 15.4 & 14.0 & 12.8 & 10.5 & \\
\hline Pregnant women receiving iron tablets (\%) & 57 & 68 & 88 & 84 & -4.5 \\
\hline Routine immunisation coverage of & 80.3 & 86 & 90 & 80 & -11.1 \\
\hline 1year-olds, DPT3 (\%) & & & & & \\
\hline Routine immunisation coverage of & - & 97 & 96 & 92 & -4.2 \\
\hline 1 year-olds, BCG (\%) & & & & & \\
\hline Routine immunisation coverage of & 80.3 & 86.2 & 90.3 & 80 & -11.4 \\
\hline 1 year-olds, measles (\%) & & & & & \\
\hline Contraceptive prevalence rate (\%) & 38.9 & 37.8 & 40.0 & 41.7 & 0.8 \\
\hline $\begin{array}{l}\text { Cumulative number of TB and malaria } \\
\text { cases detected and treated }\end{array}$ & 70,189 & 71,190 & 70,514 & - & \\
\hline $\begin{array}{l}\text { N umber of malaria cases detected (per } \\
10,000 \text { population) }\end{array}$ & 5.7 & 5.2 & 3.3 & - & \\
\hline $\begin{array}{l}\text { N umber of malaria cases treated (per } \\
10,000 \text { population) }\end{array}$ & 4.4 & 5.2 & 3.2 & - & \\
\hline
\end{tabular}

Source MOHP, 2005

H IV / AIDS: H IV isagrowing concern. Theprevalence of HIV infectionsis estimated at 0.5 percent in the 15-49 years age group, with a 3:1 malefemale ratio. Thenumber of HIV infected people is estimated to be around 70,000 . However, theprevalencerateamong specific higher risk and vulnerablegroups (such as female sex workers and injecting drug users) exceeds five percent. Therefore, $\mathrm{N}$ epal is in a "concentrated epidemic" stage. A mong high risks groups, seasonal labour migrants comprise 40 percent of those with H IV infection, followed by clients of sex workers. The interaction of the higher risk groupswith amuch larger but lower risk population through unprotected sex has the potential to turn the concentrated epidemic into a generalised epidemic. That may, within a decade, have a devastating effect on theeconomy because it would affect people of theeconomical ly productive age group (1549 year-olds).

It is estimated that by theend of the decade, 100,000 to 200,000 young adults will beinfected by HIV, and 10,000-15,000 may die of AID Sannually, making it the leading cause of death in the 15 to 49 years age group (M DG progress report 2005). The number of children orphaned by HIV/AIDS is about 13,000 . 
Nepal must urgently strengthen its response to the threat of HIV / AIDS. Therehave been some positiveactions in the past year in terms of translating the national HIV/AIDS strategy into a broadly owned operational plan, through improved participation of and coordination among the various stakeholders. The $\mathrm{N}$ epal $\mathrm{H}$ ealth Sector Programme Implementation Plan (2004-2009) emphasises that the Essential $\mathrm{H}$ ealth Care Package should also include A ID S/ ST D (Sexually Transmitted Diseases) control. N epal's policy on A ID S and ST D control was adopted in 1995 with 12 key policy statements focusing mainly on multi-sectoral preventive measures to beimplemented in partnership with NGO s in an integrated and decentralised manner. A new national H IV strategy is currently being prepared through a participatory process to cover the period beyond 2006. The new strategy and operational plan are also expected to include a strong monitoring and evaluation framework.

In the past one year, there has been an attempt to establish a multi-sectoral, semi-autonomous entity for coordinating actions against H IV/AIDS with space for public-private partnerships. This would help towards overcoming one of themain hurdlesfacing theH IV / AIDS programme in N epal, i.e. the lack of appropriate institutional mechanisms. The completion of the task would pave the way for more effective and efficient implementation of the fairly good plans and strategies that are already in place.

Community programmes: As part of the overall sector reforms, the government has been transferring health facilitiesto local bodiesor management committees. The transfer of health institutions slowed down after 2004/ 05 when a total of 1,303 sub-health posts (out of 3,129), 77 health posts (out of 697) and 32 primary health care centres (out of 186) had been transferred (T able6.4). A non-governmental organisation ismanaging onedistrict hospital.

The government launched the community health insurance programme at Urlabari of M orang district and D umkauli of $\mathrm{N}$ awalparasi district. Two new hospitals al so came into operation in M ugu and D olpa districts in 2004/ 05. 


\begin{tabular}{|c|c|c|c|c|c|c|c|c|}
\hline \multicolumn{4}{|c|}{$\begin{array}{l}\text { Fiscal Year } \\
\text { N umber of health facilities }\end{array}$} & $\begin{array}{l}2001 / 02 \\
4,429\end{array}$ & $\begin{array}{l}2002 / 1 \\
4,408\end{array}$ & $\begin{array}{l}2003 / 04 \\
4,401\end{array}$ & $\begin{array}{l}2004 \\
4,40]\end{array}$ & $\begin{array}{l}\text { \% Change } \\
0.0\end{array}$ \\
\hline \multirow[t]{3}{*}{ Region } & \multirow{2}{*}{\multicolumn{3}{|c|}{$\begin{array}{l}\text { N umber of } \mathrm{H} \text { ealth } \\
\text { Facilities } \mathrm{H} \text { anded-over }\end{array}$}} & \multicolumn{5}{|c|}{ Facilities handed-over by Fiscal year } \\
\hline & & & & $2002 / 03$ & & & & $4 / 05$ \\
\hline & SHP & 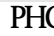 & HP & SHP & SHP & PHC & SHP & $\mathrm{HP}$ \\
\hline Eastern & 361 & 7 & 15 & 127 & 234 & 3 & & 6 \\
\hline Central & 458 & 18 & 45 & 136 & 176 & 3 & 147 & 6 \\
\hline Western & 307 & 2 & 5 & 160 & 147 & 2 & & 5 \\
\hline M id-Western & 122 & 4 & 10 & 35 & 86 & 4 & - & 10 \\
\hline Fr-Western & & 1 & 2 & 10 & 45 & 1 & - & 2 \\
\hline Nepal & 1303 & 32 & 77 & 468 & 688 & 13 & 147 & 29 \\
\hline
\end{tabular}

Source MOHP, 2005

In programmeterms, progress in selected areas within the Essential H ealth Care Services during 2004/ 05 is:

(i) Immunisation of morethan 10 million children between ninemonths and 15 years against measles (second opportunity), distribution of vitamin $\mathrm{A}$ and deworming tablets to six and 59-month-olds as part of the Integrated $\mathrm{M}$ anagement of $\mathrm{C}$ hildhood IIIness (IM CI) programme,

(ii) Distribution of oral re-hydration solution (ORS), albendazole tablets and IEC materials on nutrition; procurement of acute respiratory infection (A RI) sound timer, Salter scale and arm measuring tape for use in diarrhoea and ARI control,

(iii) Provision of safe delivery service by trained health workers to over 120,000 expectant mothers, procurement of delivery kitsfor distribution and expansion of basic essential obstetric care (BEO C) to 10 districts, and

(iv) Diagnosis and treatment of over 13,000 tuberculosis patients, spraying (twice) in districts with high malaria risk, distribution of insecticide treated nets, distribution of test kits against $K$ alzazar and continuous surveillance of malaria and $K$ al a-azar affected areas, provision of antiretroviral therapy (ARV) to 150 A ID S patients, launch of thePrevention of $M$ other to Child Transmission (PMTCT) programme in three hospitals, and provision of self-employment training to $20 \mathrm{H} \mathrm{IV}$ infected persons.

${ }^{8} \mathrm{~N}$ ot included are 442 private and I/ N GO run health facilities. 
Table 6.5: Budgetary analysis of health sector

(Rs. '000)

\begin{tabular}{|c|c|c|c|}
\hline & $2002 / 03$ & 2003/04 & $2004 / 052005 / 06$ \\
\hline H ealth budget and expenditure & Actual & Actual & Revised \\
\hline & Expenditure & Expenditure & Expenditure Budget \\
\hline Expenditure on health ${ }^{9}$ & $3,807,672$ & $3,915,154$ & $4,964,1377,555,431$ \\
\hline Year-on-year change & -0.1 & 2.8 & $26.8 \quad 52.2$ \\
\hline H ealth expenditure as $\%$ of total expenditure & 4.5 & 4.4 & 4.9 \\
\hline H ealth expenditure as $\%$ of health budget & 78.1 & 77.6 & 100.0 \\
\hline $\begin{array}{l}\text { Expenditure in Essential Health Care Services } \\
\text { (DHO HC, HP, SH P) }\end{array}$ & $1,245,767$ & $1,488,303$ & $1,705,3401,958,066$ \\
\hline Share in health expenditure (\%) & 32.7 & 38.0 & $34.3 \quad 25.9$ \\
\hline Annual change in $\%$ & 3.8 & 19.5 & 14.6 \\
\hline $\begin{array}{l}\text { Expenditure in health services (Programmes: } \\
\text { central level) }\end{array}$ & 777,227 & 722,195 & $1,404,6342,763,632$ \\
\hline Share in health expenditure $(\%)$ & 20.4 & 18.4 & $28.3 \quad 36.6$ \\
\hline A nnual change in \% & -0.4 & -7.1 & 94.5 \\
\hline Expenditure in health services (Programmes: district level) & 311,398 & 299,800 & 206,166 \\
\hline Share in health expenditure (\%) & 8.2 & 7.7 & 10.7 \\
\hline A nnual change in $\%$ & -11.1 & -3.7 & $\begin{array}{ll}-31.2 & 293.7\end{array}$ \\
\hline Expenditure in hospitals & 839,034 & 911,414 & $1,044,7841,154,535$ \\
\hline Share in health expenditure (\%) & 22.0 & 23.3 & $21.0 \quad 15.3$ \\
\hline Annual change in $\%$ & -19.1 & 8.6 & 14.6 \\
\hline
\end{tabular}

Sarce MOF, 2005a

Expenditure: In 2004/05, MOHP spent Rs. 3.1 billion (69.2\% of the allocation) on 37 development projects, which included five district-level programmes and 21 other projects. Of the total health expenditure in 2004/ 05, Essential $\mathrm{H}$ ealth Care Services (D H O , HC, H P and SH P) accounted for 34.3 percent, health services (central level) 28.3 percent and hospitals management 21.0 percent.

\section{WATER SUPPLY AND SANITATION}

A ccess to safe drinking water and basic sanitation is a PRS priority. ThePRS aims to raise water supply coverage from 71 percent $^{10}$ to 85 percent. The Tenth Plan al so aims at raising availability of sanitation facilities to 50 percent of thepopulation by 2006/ 07 (from 25\%). Thecoverage of water supplywas 75 percent and that of sanitation facilities 46 percent in 2004/ $05^{11}$. H owever, the PRS target is unlikely to be met because many systems need to be rehabilitated ${ }^{12}$. The Rural Water Supply and Sanitation Fund Development Board (RWSSFD B) - that is engaged in providing Rural Water Supply and Sanitation (RWSS) services - estimates that only 86.3 percent of the PRS target will be attained during the Tenth Plan period.

\footnotetext{
${ }^{9}$ Spending by the Ministry of $\mathrm{H}$ ealth and Population only.

${ }^{10}$ This refers to the situation at the end of the N inth Plan (FY 2001/ 02).

${ }^{11}$ Annual Progress Review, 2004/ 05, Ministry of Physical Planning and Works.

${ }^{12} \mathrm{~N}$ epal Community-Based Water Supply and Sanitation Project Preparation Technical A ssistance, Final Report, ARD/CMS/ICON, 2003.
} 
Even though thePRS target may not bemet, there is evidence of reasonable progress in the sector as a whole which is apparent in: (i) the setting of quality standards and water quality monitoring (tube wells in the Terai have been tested for arsenic and microbiological contamination); (ii) the efforts to raise service standards (targets set for "high" and "medium" standard during Tenth Plan are $5 \%$ and $10 \%$, respectively); (iii) theemphasison rural sanitation and hygiene; (iv) thefocuson remote/ interior areas and un-served populations; and (v) therecognition of water as avehiclefor social changeby mainstreaming gender, caste and ethnicity.

\section{Table 6.6: Major achievements in drinking water and sanitation}

\begin{tabular}{|lrrrrr}
\hline Indicator & \multicolumn{3}{c}{ Fiscal year } & & \% Change \\
& $2001 / 02$ & $2002 / 03$ & $2003 / 04$ & $2004 / 05$ & Over 2003/04 \\
$\begin{array}{l}\text { Population with access to drinking } \\
\text { water (\%) }\end{array}$ & 71.6 & 72.8 & 73.5 & 75.5 & 2.7 \\
H ouseholds with sanitation facility (\%) & 20.0 & 26.2 & 39.0 & 46.2 & 18.5 \\
\hline
\end{tabular}

Source MOPPW , 2005

A RWSS strategy and action plan has been developed and approved and this provides a framework for rational ising sectoral institutions and communitybased implementation processes in accordance with the decentralisation policy and the PRS. The N ational Water Supply and Sanitation Sector Policy (1998) (N W SSSP) was revised in 2004. M ainstreaming gender, casteand ethnicity is akey component of the revised policy. Thegovernment has also for mulated a comprehensive sector plan that al so spells out the resource need ${ }^{13}$.

At the implementation end, the Department of Water Supply and Sewerage (D W SS) has begun restructuring, which includes (i) handing over appropriate water supply schemes to local bodies and/ or communities in the districts after undertaking necessary repairs and rehabilitation (the need for maintenanceand suitability for transfer areassessed through field inspections and by classifying theschemes by their size, complexity, stage of development and existing condition), and (ii) reorganising district offices into 22 division offices. A draft law seeking to make the RWSSFDB a fully autonomous, permanent body has been prepared. Two major projects - formulated in accordance with the sector policy - are under implementation.

The D epartment of Water Supply and Sewerage had 13 projects and budget of Rs. 1.3 billion in 2004/ 05. The DWSS operates nationwide focusing on

${ }^{13}$ There is a N ational Water Plan (2002-2017) and, for some districts, district water profile(s). 
rural areas (communities larger than 1,000 people) and small towns. In 2004/ 05 the DWSS: (i) completed 53 district-level schemes to supply water to an additional 123,600 people; (ii) extended water supply to 11,000 people of Biratnagar sub-metropolitan city (ward no. 1, 4 and 5) and Tanki Sinubari VDC (ward no. 3 and 11); (iii) completed and handed over the Manghad water supply schemeto users' committee; (iv) installed a deep tube well each in G ulariya, Topgachi and D hulabari; (v) handed over 40 water supply schemes to users' committees after repair and rehabilitation; (vi) carried out major maintenance and rehabilitation of 80 schemes damaged by natural disasters; (viii) constructed 30,000 latrines by involving N GO s and beneficiary organisations; (ix) completed rainwater drainage in $\mathrm{H}$ anuman $\mathrm{N}$ agar and Gorkha towns; and (ix) tested 40,000 tube wells in the Terai for arsenic contamination. O verall, thereported physical progress (annual weighted) was 88 percent and financial progress was 64 percent.

The DWSS is implementing two projects which could have far reaching implications for theentire sector. A mong them, the Community-based Water Supply and Sanitation Project (CWSSP) aims to provide rural water supply and sanitation services to 1,200 communities in 21 districts, including 12 districts from Mid-west and seven from Far-west. Similarly, the Small Town Water Supply and Sanitation Sector Project (ST W SSSP) is a demand-driven project involving beneficiary ownership, cost recovery ${ }^{14}$, participatory implementation and multi-agency involvement.

R ural W ater Supply and Sanitation Fund D ev el opment:TheR ural Water Supply and Sanitation Fund D evelopment Board (also known asFund Board) is a government agency involved in community-based rural water supply and sanitation. The Fund Board undertakes only projects included in the district development plansas astrategy to involve the DDC sin monitoring and postconstruction support. The Fund Board projects place emphasis on the meaningful participation of vulnerable and excluded groups - including women, D alits (consider ed "untouchable") and Janajatis. D etailson theCWSSP, ST WSSSP and Fund Board are provided separately (A nnex 6.4).

\footnotetext{
${ }^{14}$ Water U sers' Groups have to bear 50 percent of the capital cost (5\% cash and $15 \%$ labour/ materials/ cash payment as upfront contribution, and 30\% loan from TDF to be paid back as monthly tariff) and the entire cost of system operation, maintenance and expansion.
} 


\begin{tabular}{|lrrrr|}
\hline Table 6.7: & Budgetary analysis of the water supply and sanitation sector & (Rs. '000) \\
\hline Indicators & $2002 / 03$ & $2003 / 04$ & $2004 / 05$ & $2005 / 06$ \\
& Actual & Actual & Revised & Budge \\
& Expenditure & Expenditure Expenditure & Allocation \\
Expenditure on water supply & $2,152,363$ & $2,582,874$ & $2,732,057$ & $4,638,031$ \\
Year-on-year change & 13.0 & 20.0 & 5.8 & 69.8 \\
Water supply expenditure as \% of total expenditure & 2.6 & 2.9 & 2.7 & 3.7 \\
Water supply expenditure as \% of water & & & & \\
supply budget & 57.0 & 74.7 & 76.2 & 100.0 \\
Fund Board expenditure & 265,000 & 374,755 & 413,661 & 519,439 \\
Share of Fund Board expenditure (\%) & 12.3 & 14.5 & 15.1 & 11.2 \\
Expenditurein community-based W SSP & 0 & 1,388 & 86,082 & 120,373 \\
Share of community-based W SSP (\%) & 0.0 & 0.1 & 3.1 & 2.6 \\
Expenditure in rural drinking water projects & 92,784 & 134,245 & 146,161 & 420,000 \\
Share of rural drinking water projects (\%) & 4.3 & 5.2 & 5.3 & 9.1 \\
Expenditurein small town W SSSP & 69,032 & 122,270 & 312,138 & 717,508 \\
Share of small town W SSSP (\%) & 3.2 & 4.7 & 11.4 & 15.5 \\
Melamchi Drinking Water project & 639,293 & 470,092 & 627,517 & $1,519,700$ \\
Share of M elamchi Drinking Water project (\%) & 29.7 & 18.2 & 23.0 & 32.8 \\
\hline
\end{tabular}

Source: MOF 2005a

The Fund Board completed 317 schemes serving 225,000 people and has launched another 110 new schemes after completing the predevelopment and development phases in 2004/05 as against its Tenth Plan target of providing water supply and sanitation services to 813,000 people. Theprogress in 2004/ 05 includes: (i) completion of 35 water supply schemes (target: 45); (ii) commencement of construction in 110 schemes (target: 330); (iii) completion of development phase for 342 schemes (target: 360); (iv) completion of pre-feasibility study for 443 schemes (target: 360); (v) performing water quality tests in 325 cases (target: 980); and (vi) organising 25 training programmes for Support Organisation staff (target: 35). Additionally, a "vision document" has been prepared to clarify guidelinesand refine policies. A mong others, the vision comprises a pro-poor strategy, expansion plan (especiall ly for remotear eas and backward communities) and a sanitation programme. A working policy on water harvesting has al so been prepared and the N WSSSP document has been translated in 10 ethnic languages and distributed. Theinability of theFund Board to meet itstargets

\footnotetext{
${ }^{15}$ Spending on drinking water and sanitation by DWSS, Fund Board, N epal Water Supply Corporation and the M LD. Expenditure by Solid Waste M anagement and Resource M obilisation Centre and lending for water supply by the Town D evelopment Fund are not included.
} 
waslargely dueto difficulties of monitoringimplementation in theinsurgencyaffected areas and delays in concluding the loan agreement with the World Bank for second phase activities (A nnexes 6.3 and 6.4).

A review of thesector budget ${ }^{16}$ reveals that water supply sector spent only 76 percent of allocation in 2004/ 05. TheF und Board accounts for only 15 percent of the spending and the M elamchi D rinking Water Project accounted for 23 percent of expenditure in 2004/05. The Small Town Water Supply and Sanitation Sector Project accounted for 11.4 percent of the spending ${ }^{17}$.

\footnotetext{
${ }^{16}$ Several agencies, including M inistries of Education, $\mathrm{H}$ ealth, Local D evelopment and I/ N G O s and local bodies, are involved in water supply, sanitation and hygiene. The budget included in the anal ysis includes only that for the DWSS, Fund Board, N epal D rinking Water Corporation and one major project of the MLD.

${ }^{17}$ This does not include Rs. 47.7 million lent by the Town D evelopment Fund in 2004/ 05; the projected lending for 2005/ 06 is Rs. 299.4 million.
} 

Section VII

\section{Social Inclusion and Targeted Programmes}

Overview

A fundamental premise of Tenth Plan/ Poverty R eduction Strategy has been the recognition that development efforts over the past 50 years have not reached and benefited all $\mathrm{N}$ epalis equally. Poverty has declined by eleven percentage points between the period covering 1995/ 96 and 2003/ 04(CBS, 2004) but the decline has not been even, in terms of outcomes or different groups and regions. The data also show that some groups have benefited more than others. Hence, the incorporation of the "Inclusion Pillar" in the PRSisrecognition by government that women, $D$ alitsand J anajatis have been excluded from access to services and economic opportunities as have people living in the Mid- and $\mathrm{Far}$-western regions.

The PRSP strategy for overcoming social exclusion envisages working on three mutually complementary tracks:

- A ctions aimed at structural changein institutions and policies to ensure disadvantaged groups access to economic resources, social services and decisions that affect them

- Insuring access for excluded groups in mainstream programmes, and

- Targeted programmes and safety netsfor thosew ho are disadvantaged or who areespecially vulnerabledueto age, illnessor physical/ mental disability.

Structural Change and mainstreaming the excLuded GROUPS

Thegovernment has madea number of effortsto makestructural changes in mainstream policies and programmes to ensure equal access to disadvantaged groupsto services, economic opportunitiesand influence. Thefocus has been on removing bar riers caused by geography aswell as those caused by socially defined characteristics such as gender, caste, ethnicity, language or religion. A mongthepolicylevel initiativesundertak en to makepublic resourceallocation and service delivery more inclusive are:

i) Ensuring inclusive programming in all sectors,

ii) Making poverty index basis for block grants to local bodies, 
iii) Developing a framework for addressing the problems of deprived communities/ regions,

iv) Eliminating legal discrimination,

v) Promoting affirmative action in public service,

vi) Strengthening social mobilisation, and

vii) Generating data at all levels and analysing them in terms gender, caste and ethnicity, and designing special mechanism in sectoral MIS systems for monitoring output/ input indicators as well as development outcomes for targeted groups.

\section{TARGETED PROGRAMMES}

The targeted programmes are broadly of two types: programmes targeted to remote areas mainly for local infrastructure development and group-based programmesfor social mobilisation, capacity building, incomegeneration and empowerment. The government implemented 32 targeted programmes in 2004/ 05 (A nnex 7.1). A mong them, one of the major efforts, aimed at social inclusion is introduction of the Poverty Alleviation Fund (PAF).

Poverty Alleviation Fund: The PAF was created as an autonomous institution in August 2003 and is cur rently funded by thegovernment and the World Bank. ThePA F implemented itsprogrammes in 196 VDCs, mobilising 582 community organisations ( $\mathrm{CO} \mathrm{s}$ ) of the six initial programme districts in 2004/ 05. It also supported eight proposals from $13 \mathrm{CO}$ s in other districts. Programmes of the PAF have produced quick results and were largely unaffected ${ }^{18}$ by the political instability and conflict. The major reasons for the success are direct funding and the freedom of the communities to choose the productive activities they want to undertake. 0 ther reasons are the rapid implementation of programmesand thevisibility produced by thequick results.

The PAF is to cover an additional 19 districts in 2006/ 07 with an allocation of Rs. 508 million in 2006/ 07 (73\% over the spending in 2004/ 05) and aims to support 1,517 group-based incomegeneration and community infrastructure development schemes. Additionally, it is also aiming to support another 80 innovative proposals from different districts. Early outcomes of the PAF indicates its ability to become a reliable institutional modality for targeted interventions to bring excluded population groups into the mainstream of development.

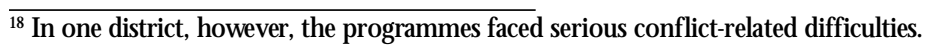




\section{Box 8: The Poverty Alleviation Fund}

The Poverty Alleviation Fund (PAF) was set up under the Poverty Alleviation Fund Ordinance 2060 and is directly linked to thethird pillar of theTenth Plan/ PRSP. Thethird PRSP pillar (T argeted Programmes) emphasises theneed for special effortsto bring excluded

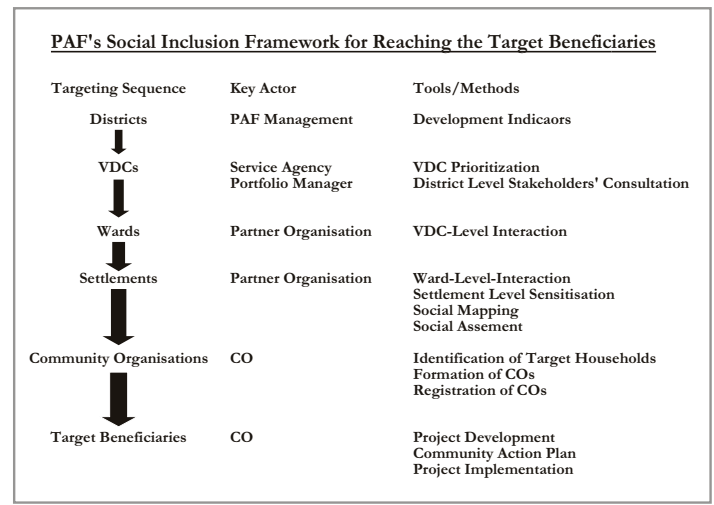
communities into the development mainstream. The main elements of social inclusion under PAF are: (i) A ddressing spatial exclusion by focusing on most deprived districts whileproviding servicesin other poverty-stricken areas as well, (ii) Reaching the poor - the targeted beneficiaries - with the ser viceswhilemaintaining social harmony, and (iii)

Focusing exclusived y on marginalised communitiestaking adequatecareto ensurecommunity cohesiveness and solidarity.

PA F has adopted a demand-led, community-based approach to poverty alleviation where thetargeted communities are given full decision-making authority to prepare, implement and manage their sub-projects. PAF'stargeted beneficiaries includethevery poor, w omen, $D$ al its and Janajatis and at least $80 \%$ of Community O rganisation (CO ) members arefrom among thetargeted groups. ThePA $\mathrm{F}$ al so requires at least $50 \% \mathrm{CO}$ membersto bewomen and that the officeholders in the $\mathrm{O}$ s(Chairperson, Secretary and Treasurer) arefrom the targeted groups. PAF provides direct support to the $\mathrm{C}$ sfor implementing theprogrammes they propose as a strategy to ensure efficiency, transparency and ownership. The Partner Organisations (POs) comprising of $\mathrm{N}$ on-governmental Organisations (NGOS), private sector organisations and local government bodies (DDC s/VDCs) support community organisations through social mobilisation, technical assistance and capacity-building in organising, planning, implementing and managing the sub-projects. The four major programme components of PAF are (i) social mobilisation (ii) income generation (iii) small community infrastructure development, and (iv) capacity-building.

ThePAF sub-projectsoriginateat thegrassrootsand ther efore, the demand for such projects isvery high. Theben ficiary communitieshavenot only demonstrated interest to undertake the sub-projects but have al so made contributions towards meeting the programme costs. The PAF's main challenge now is to strike a balance betwen rapid implementation and institution-building for enhancing the capacity of thecommunity organisations. Someissues related to the sustainability of PAF interventions are

- Establishing linkages with markets for sustaining income-generating activities

- Providingappropriatetechnology support for differ ent activitiesincludingbuilding linkswith existing ser vice structures

- Building safety nets through insurance, particularly for livestock

- Exploring alternative to livestock-based activities for the landless, and

- Building community capacity for managing therevolving funds. 
Food-for-W ork: The Food-for-Work ( $F f W$ ) is another ongoing targeted programme ${ }^{19}$. The FfW is a self-targeting programme that provides seasonal wageemployment to poor familiesin rural areas. Theprogramme- implemented in the food-deficit districts - has made a continuing contribution towards food security in terms of both availability and access (ideally, without distorting local food markets $\left.{ }^{20}\right)$. Food aid is used as incentive for building local infrastructures such as muletracks and roads, which further contribute towards food security by improving access. The Rura Community InfrastructureProgramme(RCIP) built about $132 \mathrm{~km}$. village roads and 47 houses (for ex-bonded labourers) in 2004/05. It also car ried out river training workson about onekilometre of river bank. H owever, theprogressislower than that attained in 2003/04. Theconflict was one of the reasons for the slowdown.

Programmestargeted to women: Several agenciesareimplementing different programmesthat reach out to women. Thelargest all-woman programmeisthe Women D evelopment Programme (WDP) being implemented by the District Women D evelopment O ffice (DWDO ) of the M inistry of Women, Children and Social Welfare (M WCSW). The programme covers all the 75 districts. A total of 4,497 women groups were mobilised for income generation under the programme in 2004/ 05, and 161 women cooperatives were provided with Rs. 6.29 million as "seed money" in 41 districts. Even though seed money tends to encourage dependency, if used carefully, it can provide vulnerable groups the vital start-up support. Ther efore, a plan to phaseout such support isasimportant as is the compulsion to have a head start to produce quick results.

A WD P monitoring study (N PC, $2005_{\mathrm{e}}$ ) in three districts has reveal ed that (i) the WDP generally suffers from inadequate budget, particularly for funding programmes, as well as from procedural delays in the release of funds; (ii) there is an apparent lack of process vision and the DWDO staff do not possess adequate knowledge and skills to identify critical processes in WDP implementation; (iii) the programme is monopolised by the elites comprising of women with access to markets, while the participation of disadvantaged groups especially Dalits remains low; (iv) though women have generally benefited through participation in the WDP, there are imbalances in the distribution of its services to beneficiaries; (v) TheWD P has generally helped to improve the social and economic status of participating women and the level of beneficiary satisfaction with WDP service delivery has been rated

\footnotetext{
${ }^{19}$ Besides the Food-for-Work programme, there are other food-based interventions targeted to different groups such as the primary school feeding programme and mother and child healthcare support programmes.

${ }^{20}$ This aspect is important considering the lack of a sound food monitoring system and the tendency to rush food aid based on perceived shortages and demands of interest groups.
} 
between "moderateto good" on a 4-point scale; and (vi) overall, theDWDO has been trying to maximise outputs despite operating with limited physical, financial and human resources.

The government has introduced a Gender Responsive Budgeting (GRB) framework and hasformed a committee at theM inistry of Finance(M OF) to institutionalise the idea for making allocations with a special focus on the needs of women. The N PC has also introduced a classification system of programmes/ projects using the gender code, and gender budget audits have been completed in the M inistries of Agriculture, $\mathrm{H}$ ealth, Education, Local Development and Women, Children and Social Welfare. Also in place are gender disaggregated indicators; and a monitoring mechanism is being put in place to measure the outcomes.

A N ational Plan of Action for gender equality and women empowerment was approved by thegovernment in September 2004 and gender focal points have been appointed in key sectoral ministries and at the district level (i.e. DWDO s). The 2005 amendment of theCivil ServiceA ct includesa provision for formulating affir mativeaction policiesfor women, D alitsand disadvantaged Janajatis in government service and has exempted the age bar for temporary women staff wishing to apply for positions advertised by thePublic Service Commission (PSC). Coaching classes and capacity-buildingtrainingswereal so held to prepare eligiblewomen candidates for PSC and other examinations: 19 were coached for taking joint- and under-secretary level examinations, 166 for taking examinations for entry level officer positions and another 51 for taking other entry level examinations.

Kamaiya rehabilitation: The programme to liberate and rehabilitate $K$ amaiyas (formally, bonded labourers) is another successful targeted programme. The K amaiya system was abolished in July 2000 and several government and non-government agencies, including donors, have implemented various programmes to rehabilitate former Kamaiyas in five Terai districts of Mid-and Far-western D evelopment R egions. Some 12,019 former K amaiyas were given $1,575.6 \mathrm{ha}$. of land for resettlement by end2004/ 05 and 8,000 were provided support for building houses at the rate of Rs. 10,000 per family. Additionally, another Rs. 16.7 million has been distributed to 827 former K amaiya groups through $\mathrm{N}$ epal Government/ ILO revolving fund and identity cards have been issued to about 12,000 former K amaiyas. D ifferent government agencies have provided skill training to 6,114 former K amaiyas - at least one person from each family. A nother 17,000 former 
K amaiyas received 23 types of skill-based training through ILO assistance. The government has established a Land Bank with a view to providing land to the landless, including former K amaiyas.

D espitethesuccess, someprogrammatic deficiencies do remain and theser late to inclusion of only K amaiy as identified originally for support, poor quality of land received, inadequacy of skill training, unavailability of good incomegeneration opportunities, domination of labour-based occupations (among employment options), continuation of thepractice of using freelabour or paying them below minimum wageand wagediscrimination (between men and women, etc.). These issues need to be addressed in order to assist the integration of the former Kamaiyas in society. The M inistry of Land Reform and M anagement has plans to deal with some of these issues under its programmesfor 2005/ 06.

D espiteshortcomings, theoutcomesr lated to rehabilitating for mer $\mathrm{K}$ amaiyas so far is proof of the ability of society to root out deeply entrenched social evils - where there is the will. It was possible through efforts of both government and non-government agencies, including donors - a modality that has to be the core of all inclusive and targeted programmes.

Micro-finance: The micro-credit programme is another successful inter vention that targets therural poor, especiallywomen. M any organisations provide micro credit services in different parts of the country, some in conjunction with other social interventions. Many micro financeinstitutions (M FIs) have also begun adopting international best practices.

However, coverage of micro-credit isstill limited ${ }^{21}$ and theconflicthasal so affected the people's access to loans. A Iso important is the need to expand micro-finance outreach, especially to the very poor sections of the population, and to further enhancethecapacity and governance of the M FIs Thegovernment ispursuinga threepronged approach to develop MFIs. provisioning fund for lending and capacity building, improving the regulatory framework, and restructuring and rationalising public institutions engaged in rural finance. In 2004/05, the government provided Rs. 185.2 million to the Rural Midro Finance D evelopment Centre (RMDC), which provides bulk loans and capacity-building support to MFIs. The government also lowered the re-financing rate to the RMDC from four to two percent in 0 ctober 2004. TheRM DC disbursed Rs. 320.6million and trained 1,146 M FI staff and 44,506 M FI clients in 2004/ 05.

${ }^{21}$ N LSS 2003/ 04 indicates that only $10.1 \%$ of total household loans of the poorest quintile came from banks and other formal sources. 
The government enacted the Bank and Financial Institutions 0 rdinance in A pril 2004 and brought M FIs under the regulatory oversight of the central bank. Likewise, the Agriculture D evelopment Bank (ADBN), Small Farmer D evelopment Bank (SFD B) and G rameen Bikas Banks (G BBs) arealso being restructured.

P rojects targeted to $D$ alits and disadvantaged Janajatis: Twelveministries implemented another 31 projects/ activities under Targeted Programmesin 2004/ 05. H owever, most of these programmes had limited funding, and therefore, reach. These programmes include the Tribal and Ethnic Groups U pliftment and Praja D evelopment (TEGU PD ) programmeand the N eglected, D eprived and $D$ alit U pliftment D evelopment Committe (N DDUDC).

The following activities were undertaken under the TEGU PD in 2004/ 05: (i) ten research studies; preparation of the lexicon in 10 languages; literacy programme in two languages; and distribution of scholarships to 400, school dress to 1,000 and text books to 1,000 students from the Praja community. Similarly, the following were the achievements of the NDDUDC: excellence awards to 12 students in higher education; and 52 radio programmes were produced and broadcasted to raise awreness on about exclusion and the need to be inclusive. Several incomegeneration and skill development activitieswere also conducted.

Generally, the outcome of theTargeted Programmescan beenhanced through proper planning of theinterventionswith clear inclusivestrategies and adequate funding. The Targeted Programme portfolio also needs to be reviewed for incorporating thefindings of morerecent literatureon exclusion, and for setting measurabletargets. Theseactivitiesw ould help to further consolidatetheTargeted Programmes. The government has already reduced the activities from 37 projects/ programmes in 2002/ 03 to 32 in 2004/ 05.

O ther programmes: The Decentralised Local Governance Programme (DLGSP) and Decentralised Action for Children and Women (DACAW) are some other pro-poor programmes, even though they are not grouped as "T argeted programmes". U N ICEF is supporting the DACAW programme in 23 districts, including nine in the $\mathrm{M}$ id- and Far-western D evelopment R egions. The programme focuses mainly on women and children. The DACAW programme'smain goal isto demonstratehow local-level planning and people's participation in decision-making can help to enhancelocal capacity. TheDACAW also contributes to both the poverty alleviation objectives and the MDGs. It promotes strengthened community-based ownership, particularly by forming 
federations and paralegal committees for empowering communitiesto increase the participation of disadvantaged households. The DACAW has also made efforts to address the effects of the conflict on local development activities.

The DLGSP programme is being implemented by the MLD with UNDP support. TheV illage D evelopment Programme(VDP) isthemajor component of theD L GSP, which covers 442,819 households of 662 VD C sin 60 districts. Theprogrammeisimplemented by theDDC sand stresses social mobilisation. It isfunded through Local D evelopment Fund (LDF) and has a stated policy to support women, $\mathrm{D}$ al its and other disadvantaged groups.

\section{Funding for Targeted Programmes}

In 2004/ 05 R s. 275.9 million was all located to 32 Targeted Programmeswhich amountsto only 2.5 percent of thetotal budget. Whilealarger amount of the allocated budget was spent this year (79\% compared to only $66 \%$ in 2003 / 04), the allocation to these programmes declined in 2004/05. In terms of financing, foreign assistance (loans and grants) remains restricted to just four or five programmes/ projects. It is also evident that Targeted Programmes alone will not be sufficient to end social exclusion. Instead, the needs and priorities of women, Dalits and J anajatis must be factored into the planning and design of the mainstream development programmes across all sectors.

\begin{tabular}{|lrrrr|}
\hline Table 7.1: Targeted programmes & & & & (Rs. '000) \\
\hline & $2002 / 03$ & $2003 / 04$ & $2004 / 05$ & $2005 / 06$ \\
Targeted Programme (T P) budget & $2,144,184$ & $2,979,150$ & $2,759,801$ & $3,179,870$ \\
TP budget as \% of total & 2.6 & 2.9 & 2.5 & 2.5 \\
TP budget as \% of development budget & 5.5 & 7.1 & 5.9 & - \\
Year-on-year change (\%) & - & 38.9 & -7.4 & 15.2 \\
Foreign assistance to TP & - & - & - & $2,084,062$ \\
Foreign assistance as \% of TP budget & - & - & - & 65.5 \\
Share of 4 projects in foreign assistance & & & & \\
under TP (\%) & - & - & - & 75.8 \\
TP expenditure & $1,296,081$ & $1,964,242$ & $2,177,135$ & - \\
Expenditure/ budget ratio & 0.60 & 0.66 & 0.79 & - \\
N umber of targeted programmes/ projects & - & 32 & 32 & 31 \\
Priority ratingP1 & - & 22 & 19 & 21 \\
Priority ratingP2 & - & 8 & 10 & 9 \\
Priority ratingP3 & - & 2 & 3 & 1 \\
\hline
\end{tabular}

Source MOF, 2005a 


\section{Section VIII}

\section{Governance}

\section{Overview}

Good governance for improving service delivery, efficiency, transparency and accountability comprises the fourth pillar of the Tenth Plan/ PRSP. Improving governanceis critical for attaining thePlan's overall poverty reduction target, and therefore, cuts across all sectors and programmes. Within government, thethrust ison makingpublic services efficient, inclusiveand accountable Themain strategies towards better governance focus on public service reform, decentralisation (including fiscal devolution), and corruption control and judicial reforms.

\section{Civil service Reform}

Thegovernment hasinitiated several reformsaimed at making thecivil service responsive, efficient, accountableand inclusive. Themeasures are in different stages of implementation. In J uly 2005, the government had eliminated 7,334 vacant positions (almost all non-gazetted and non-technical) in an effort to right-size the bur eaucracy. The government has al so capped recruiting Class III and Class IV non-gazetted staff, whiletaking care not to affect the hiring of technical and officer-level staff. It has also prepared a report - based on stakeholder feedback - for improving the curriculum, question-setting and testing for public ser vice examinations. The aim is to introduce merit-based recruitment and promotion. Staff transfers have also been greatly reduced and personnel atkey ministriesarebeing trained in new skillsand procedures for enabling them to function better in a decentralised context.

Personnel database: A computerised database of government employees has been developed and an internet-based Personnel Information System (PIS) is now operational. Work to link the database to approved positions, retirements, transfers and payrolls is underway. A database of government teachers is al so in the process of being computerised; it al ready has records of 60,000 permanent teachers. The PIS is being implemented in three pilot ministries (agriculture and cooperatives, education and sports, heal th and population) and will be expanded to local development, and land reform and management and eventually to all ministries. 
Table 8.1: Selected civil senvice reform indicators

\begin{tabular}{|c|c|c|c|c|c|}
\hline \multirow[t]{2}{*}{ Indicators } & \multicolumn{4}{|c|}{ Fiscal year } & $\begin{array}{l}\text { \% Change } \\
\text { over }\end{array}$ \\
\hline & $2001 / 02$ & $2002 / 03$ & $2003 / 04$ & $2004 / 05$ & 2003/ 04 \\
\hline N umber of positions eliminated & - & 7,000 & 160 & 184 & 15 \\
\hline $\begin{array}{l}N \text { umber of women, ethnic and disadvantaged } \\
\text { candidates benefiting from coaching classes }\end{array}$ & - & - & 670 & 350 & -47.7 \\
\hline N umber of applicants to Public Service & & & & & \\
\hline Commission from disadvantaged groups: & 24,581 & 55,232 & 38,247 & 43,590 & 14.0 \\
\hline Women & 21,247 & 25,174 & 16,014 & 22,310 & 39.3 \\
\hline Dalits & 135 & 1,028 & 810 & 991 & 22.3 \\
\hline Janajatis & 3,199 & 29,030 & 21,423 & 20,289 & -5.3 \\
\hline
\end{tabular}

Source: MOGA, 2005

A performancebased management system is being piloted in thre ministries: the MOAC, MOES and MOHP, which are main service delivery institutions. Some progress has been made towards the preparation of performance improvement plans, with indicators, based on client service standards for the agriculture offices at Bara and K avrepalanchok districts. Progress, however, was constrained by inadequatefulltimestaff, poor management, funding and facilities in the "changemanagement units" of theparticipatingministries Implementation of the management development programme - senior executive management training, leadership training, and in-service training - has progressed according to plan and efforts are underway for creating a perfor mance incentive fund for rewarding good performance. A permanent body has also been established to review thesalary structureand policy. This body will recommend periodic salary increases based on the consumer price index (CPI). The government has also introduced a contributory pension scheme to makethe system sustainable.

The Civil Service Act was amended through ordinance in July 2005 for institutionalisingthegovernanceimprovement measures. Theamendment includes several reform-oriented features including affirmative action for disadvantaged social groups (for fiveyears), succession planning of senior civil servants, targeted, voluntary, early retirement, transparent annual personnel assessment, permanent pay commission, performance incentive fund, staff insurance plan and a contributory pension scheme. The government has begun to prepare necessary rules - with stakeholder consultations and in accordance with the governance reform programme - for implementing the new provisions. A governance act has also been drafted. 
A ffirmativ eaction: Thegovernment ispreparingthemechanism for affirmative action to include morewomen, Dalits, Janajatis and the disabled in government service. Themain challengeisto put a system in placethatwould not undermine themerit-based structure of thecivil servicew hilecreating spacefor social groups who have so far been largely excluded. Thegovernment al so runscoaching classes to preparecandidatesfrom excluded groupsfor thePublic ServiceE xaminations.

\section{DECENTRALISATION}

Nepal has taken major strides towards decentralisation since the enactment of Local Self-G overnance Act 1999 and its regulations, in 2000. The process has, however, sowed down sinceJ uly 2002 when the tenure of elected local bodies ended. Electionshavenot been held sincethen but successivegovernmentshave attempted to place several arrangements to keep the local bodies functioning. A fter the political change in February 2005, the government nominated chairpersons, vice-chairpersonsand membersin al DD C sbut villagelevel bodies remain without local leadership. A fter experimenting with variousmodalities for operating local bodies, there is now realisation that no alternative arrangement can replace elected representation. The conflict has also had a toll on decentralisation because many of the village development committee (VDC) secretaries have been forced to abandon their posts.

The government continued policy and programme measures to foster the decentralisation process. In 2005 it amended the Local AuthoritiesFinancial and Administration Regulations (1999). The amendment seeks to rationalise fiscal rights of local bodies, reclassify DDC s and VDCs, introduce poverty and social mapping, streamline financial procedures and improve revenue sharing arrangements. The Local BodiesFinancial Commission (LBFC) has developed a formula (that accounts for various needs and poverty status) for the allocating block grants to local bodies.

Devolution: U nder sectoral devolution, the management of a number of agriculture extension offices, sub-health posts, health posts and primary schools have been handed over to communities as envisaged in the Decentralisation Implementation Plan (DIP). The government has decided to devolve full responsibility and provide conditional grants for education, health, agriculture extension and local infrastructure to local bodies in 14 districts in 2005/ 06. A related decision involves assigning line agency officials involved in carrying out the devolved functions at the concerned DDCs until the district bodies make aternative staffing arrangements. These are major initiatives towards functional 
devolution and, if properly implemented, they can set the stage for full-fledged decentralisation.

A s a measure to reinforce local bodies, the D istrict Technical O ffices (DTO s) have been reorganised as technical units of the DDCs, and their roles and relationshipsarebeing redefined and strengthened under an action plan. A Local Service A ct has been drafted and is being finalised in consultation with stakeholders. Thisprovision seeks to enablelocal bodies to acquireand manage their own staff and movetowards buildinglocally accountableemployees. Some additional initiatives have been taken to improve governance (such as, introduction of citizen charters in all 75 districts; selective management audits; public hearings; complaint boxes and help desks; and the assignment of an officer to hear and redress complaints).

A partial expenditureanalysis by thegovernment hasindicated that on aver age, seven district-level programmes/ projects in the M LD portfolio accounted for around 53 percent of total expenditure between 2002/ 03 and 2004/05. These programmes/ projects are mainly government-funded and are directly implemented by local bodies. Based on theexpenditureanalysis, it can begenerally inferred that local bodies havebroadly been ableto improvetheir performance. Thishas been possiblelargely becausethey arenow better equipped with periodic plans, technical capacity, operating systems and operational processes.

\begin{tabular}{|lrrrrr|}
\hline Table 8.2: & Selected MLD programmes on decentralisation & & (Rs. '000) \\
\hline Programmes/ projects & $\begin{array}{r}2002 / 03 \\
\text { Actual }\end{array}$ & $\begin{array}{r}2003 / 04 \\
\text { Actual }\end{array}$ & $\begin{array}{r}2004 / 05 \\
\text { Revised }\end{array}$ & $\begin{array}{r}2005 / 06 \\
\text { Budget } \\
\text { expenditure }\end{array}$ & $\begin{array}{rlr}\text { expenditure } \\
\text { expenditure }\end{array}$ \\
& 780,662 & 984,237 & 789,994 & $1,010,000$ \\
District D evelopment Committee grant & 1352,945 & $1,833,927$ & $1,297,567$ & $1,956,500$ \\
Village D evelopment Committee grant & 240,901 & 151,744 & 200,000 & 176,000 \\
Municipal grant & - & - & 103,752 & 83,000 \\
$\begin{array}{l}\text { Decentralised Financing and D evelopment Programme } \\
\text { Decentralised Local-Self Governance }\end{array}$ & - & - & 145,556 & 275,899 \\
Support Programme & 117,116 & 978 & 11,523 & 35,000 \\
Rural D evelopment Programme & - & - & 400000 & 400000 \\
People's Participatory Development Programme & $2,491,624$ & $2,970,886$ & $2,948,392$ & $3,936,399$ \\
Total expenditure (seven programmes) & $4,569,002$ & $5,490,132$ & $6,103,388$ & $8,169,860$ \\
Total M LD expenditure & & & & \\
Seven programmes total expenditure/ & 0.55 & 0.54 & 0.48 & 0.48 \\
Total M LD expenditure & & & &
\end{tabular}

Source MOF, 2005a

An outstanding issue related to local self-governance is the different interpretation of decentralisation by agencies executing similar programmes/ projects. There are various reasons for this anomal y, including expediency to 
respond to the difficult situation on theground; lack of confidencein public sector governanceand capacity at the local level (particularly skillsfor working in partnership with CBO s/ N GO s and/ or outsourcing); emphasis on quick servicedelivery (and not on process or institution building); project orientation; entrenched desire to retain central control); and disregard of the broad oversight and residual role (not necessarily, an implementation role) of local governments. Thereareal so confusions at theimplementation level that need to becoordinated at the policy level in order to promoteand execute effective decentralisation.

\section{CORRUPTION CONTROL}

Nepal had put in place major laws aimed at controlling corruption before parliament was dissolved in May 2002. These include the Corruption Prevention A ct 2002, CIAA A ct 2002 (Second A mendment), Impeachment A ct 2002 and Act to RegulateFinancing of Political Parties 2002. O ther new laws to prevent money laundering and protecting whistleblowers are being drafted. Thelawshaveprovided a basisfor prosecutingthoseguilty of misusing public funds. But enforcement remains problematic and corruption control remains a challenge. There has, however, been increased awareness on the need to control corruption at both policymaking and operational levels.

The Commission for the Investigation of Abuse of Authority (CIAA) is the investigative and prosecuting agency. It has extensive authority to investigate and prosecute suspects. The CIAA gained both effectiveness and visibility after it began prosecuting those accused of amassing illegal wealth by the Judicial Commission for Property Investigation. It has had a conviction rate of 86.3 percent. ${ }^{22}$ Strong commitment, formulation and implementation of necessary laws have hel ped to create an effective organisation for cor ruption control. TheCIAA now has thelegal framework, investigative procedures, IT facilities and a committed workforce working to ensure accountability at all levels.

D espite the apparent success, there are questions on the ability of the CIA A to deter corruption at all levels. D elays in litigation ${ }^{23}$ have al so delayed justice. The CIAA has also not been able to absolve itself of allegations of being politically-motivated while prosecuting certain cases. M ore importantly, fear of prosecution is also said to have deter red government officials from taking

\footnotetext{
22 O ut of the 530 cases filed at the Special C ourt, in early December, 2005, the court had found the accused guilty in 290 cases.

${ }^{23} 194$ cases were pending at the Special Court as of December 4, 2005.
} 
decisions, particularly procurement-related, resulting in delaysin infrastructure works. The government formed another anti-corruption body in February 2005 - the high-level Royal Commission for Corruption Control (RCCC) with powers to investigate, prosecute and punish suspects. There were questions on the constitutionality of this body from the day it was formed and the Supreme Court annulled both the RCCC and its decisions in early 2006.

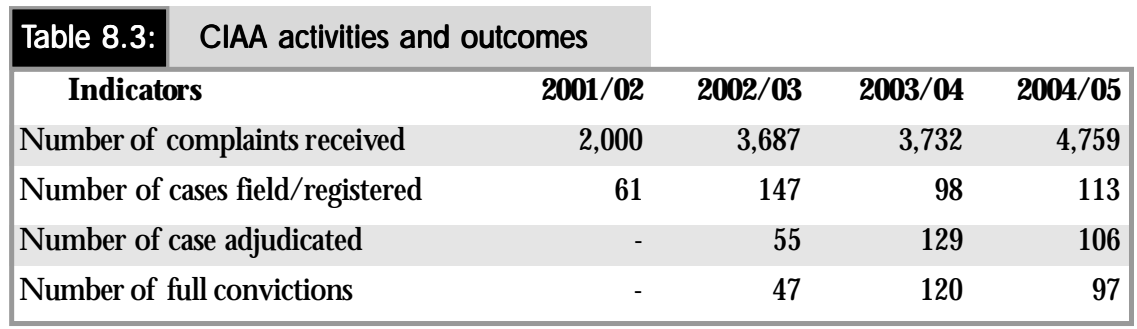

Source: CIAA, 2005

The $\mathrm{N}$ ational Vigilance Centre (N VC) works on preventive and awarenessbuilding measures against corruption. The N VC has carried out awarenessraising activities; networking between government, private and nongovernment organisations; monitoring of property statements of public officials and the service delivery of governmental organisations; complaint handling, and technical audit of development activities. H owever, the N VC needs to be adequately funded, equipped and staffed.

\section{JUDICIAL SECTOR REFORMS}

Nepa'sC onstitution hasestablished an independent judiciary with theSupreme Court as the apex body. The Supreme C ourt serves as the highest court of appeal, though it also hearslitigations, especially thoser elated to constitutionally guaranteed rights and provisions.

The foremost problem facing the judiciary is the disposal of a huge backlog of cases. Thejudiciary has prepared a strategic plan to maketheinterventions needed for enhancing justice delivery by upgrading its capacity and resources (Box 9).

Various committees were formed to study different areas of reforms in the judicial sector and most of them have completed their reports. A H igh-level Steering Committee has also been formed to expedite the reforms. This 


\section{Box 9: Strategic plan of the judiciary (2004-2008)}

The SupremeC ourt has adopted the Strategic Plan of the J udiciary 2004-2008. The plan is an effort to link the judiciary with thenational planning process. The plan clarifies the mission and vision of the judiciary and also the actions that need to betaken to attain its goals. Itsmission isto impart fair and impartial justicein accordancewith theC onstitution, laws and universally recognised principles of justice. Likewise, its vision is to establish a system of justicethat is independent, competent, inexpensive, speedy, and accessibleand worthy of public trust. The values set for the Supreme Court are: allegiance to the Constitution, independence and autonomy, duty towards society, accessibility of justice, competent justice, high ethical standards, and representation.

The plan has identified four core functions of the judiciary - adjudication, advisory, supervision and monitoring and court management. It has al so identified thefollowing 16 strategic ar eas of intervention: (1) streamlineand strengthen its management capacity, (2) pursuefor increased budgetary allocation and financial autonomy, (3) develop infrastructure and logistical support to improve court environment, (4) streamline the number and geographical distribution of courts and review existing jurisdiction, (5) strengthen the capacity of thejudiciary, (6) develop and implement an autonomoustransparent, accountable and efficient recruitment and promotion system, and work to improve the efficiency of human resources, (7) review relevant lawsand simplify court procedures, (8) ensurejudicial autonomy for making its own rules to conduct business, (9) strengthen communication, coordination and interaction with institutional and other actors, (10) develop and implement Court U ser's Charter, (11) strengthen theinvestigativeand disciplinary mechanismswithin the system to make it more transparent and accountable, (12) strengthen mediation and encourage consensus building, (13) improve court security - for judges, employees and users, (14) develop a scientific central archive for the courts, (15) develop and implement an effective case management system to reduce delay and case overload, and (16) institutionalise the legal aid programme for disadvantaged groups.

committee is aided by two sub-committees; one is responsible for the implementation of the strategic plan and the other for coordinating the reforms.

The $\mathrm{N}$ ational Judicial A cademy (NJA) was established under an ordinance issued in 2004. Itsmain function is capacity enhancement of legal professionals. Theacademy hasorganised a number of training programmesand workshops for individual sand institutions. Its ser vices areaimed at a client basecomprising of about 1,000 judges and officers and 10,000 lawyers.

Thejudiciary isestablishinga Legal Infor mation Centre(LIC) for disseminating information and to introduce computers at the courts. The introduction of computers has hel ped to speed up record keeping and hearings. Besides, efforts to establish a separate bench to hear commercial disputes are al so underway. 
Followingtheintroduction of thestrategic plan, thejudiciary hasalso reviewed and amended many court procedures. Thejudiciary also oversees the work of the D ebt Recovery Tribunal and other quasi-judicial bodies.

The judiciary has provisions for providing Free Legal A id Services to the needy. TheSupremeC ourt employstwo lawyers, and other courts onelawyer each, to provide such services (which are al so provided by other N GOs, the $\mathrm{N}$ epal Bar Council and the N epal Bar A ssociation. These groups also have programmes aimed at raising awareness about the rule of law). 


\section{Conflict and Development}

\section{Overview}

Since February 1996, the government has had to confront an armed conflict. The conflict escalated in N ovember 2001 and has so far caused about 13,000 deaths. Its impact on the economy is also more visiblenow. Delivery of basic services (health, education, for example) has been disturbed and there has been a slowdown in spending on development activities, especially in the conflict-affected areas ${ }^{24}$. Many development infrastructures, including VDC buildings, schools, health posts, roads, bridges and communication facilities, have been damaged and reconstruction has been delayed by insecurity and inadequatefunding. The conflict has al so triggered migration to the cities and abroad, and most of those moving out areyoung men and women ${ }^{25}$.

Economic performance has remained below the estimates of the Tenth Plan owing to a number of factors, mainly the conflict ${ }^{26}$. Though theGDP has not contracted and themacroeconomic situation has remained stable, GDP growth remains below theaverage of the 1990s. M any grass-root development activities such as the Food-for-Work and infrastructure-building programmes (RCIW, RAP), community development, and basic services in health, education, drinking water, agriculture and for estry have continued to function, but not at the levels in which they would have if there had been peace and security. G enerally, theprogrammesthat havemanaged to continueduring the conflict are those that involve communities. Such programmes are demand-driven, have strong community support, provide direct benefits, employ local staff, and are perceived to be transparent, accountable and non-partisan.

The third strategic pillar of the Tenth Plan stresses Social Inclusion and Targeted Programmes, which is recognition by government that exclusion and deprivation are factors that contribute to conflict. The government attempted to resolve the conflict through negotiations twice (A ugust -

\footnotetext{
${ }^{24}$ To an extent, the increased spending on security has also crowded out development expenditure.

${ }^{25}$ Thelost rural incomeseems to havebeen partly compensated by remittances but thereareother problems related with migration of the workforce, which remain to be assessed.

${ }^{26} \mathrm{~A}$ study has estimated that "lost" G D P growth will beabout 1.7 percent per annum (average) during the period 2005 to 2009 if development expenditure declines at the current rate (4.2\%) (Sungsup and Singh, 2005).
} 
November 2001 and January-A ugust 2003) but the efforts did not lead to a resolution. Faced with the choice of waiting for peace or continuing to do what is possible, it then resorted to the second option. The peace through development approach is backed up with special implementation mechanisms that involve community participation. The Integrated Internal Security and D evelopment Programme is also a part of this initiative.

D evel opment approach: Thefocus of development in conflict-affected areas has been to try and transform the dynamism and debate associated with the discord for creative endeavours. This approach entails recognising that not all conflicts are destructive and devising ways to harness the collective energies for development. O neapproach has been reaching out to thepoor, theexcluded communities and letting them take decisions on what they want to achieve and how. In terms of programmes, the approach translates into taking on projects that are local (decentralised), participatory and address to the basic needs of the poor and the excluded (income generation, delivery of basic services, etc.).

At the macro-level, the government has begun devolving services of some sectors that are very important to rural populations and the plan is to move towardsfull decentralisation in 14 of the country's 75 districts. In policy terms, the government has begun releasing all funds for local development directly to the DDCs in the form of conditional and unconditional grants. The availability of resources and space for local decision-making for selecting and implementing programmes is expected to improve both development performance and fund disbursement.

Thegovernment has identified rural unemployment, low wages and landlessness as some major issuesfacing thepoor and excluded groups. These groups are generally illiterateand do not have access to basic services provided by the public sector. They also lack skills needed for benefiting from opportunities that are available and many are forced to migrate in search or work as manual labourers. The challenge is to help these population groups to acquire the skills, capital and other support to take up activities that would help them escape from the cycle of deprivation that has been passed on through generations - which also fuels conflict.

The Poverty Alleviation Fund (PAF) in conflict-affected districts: The PAF was set up in 2004/ 05 with the aim of organising poor communities to prepare, implement and manage their development activities. The programme is underway in 582 Community Organisations of six PA F districts (D archula, 
Mugu, Pyuthan, Kapilbastu, R amechhap and Siraha), all severely affected by the conflict. Additionally, thePAF isimplementing special "innovative" programmes with $13 \mathrm{COs}$ in Baglung, Rasuwa, Makwanpur and Nawalparasi districts. of 22,000 beneficiary households that aremembers of Community O rganisations, 61 percent belong to very poor groups, 24 percent are of the "medium poor" category, and 15 percent householdsfall under the "poor" category. A majority of group members

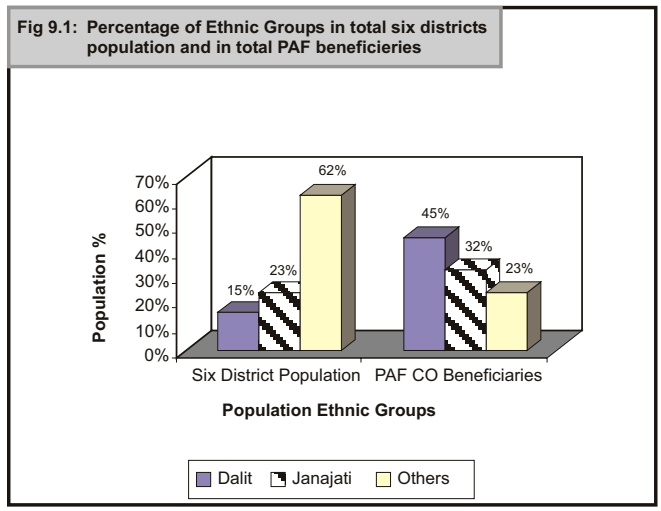
are from $D$ alit and Janajati ( $45 \%$ and $32 \%$, respectively) households and 56 percent beneficiaries are women.

ThePA F implementsincome-generating and infrastructuresub-projects. The income generation sub-projects include (i) agriculture and agro-forestry, (ii) livestock raising, (iii) manufacturing/ cottage industry, (iv) trade, and (v) serv-

\section{Table 9.1: G rowth of micro-hydro electricity generation}

\begin{tabular}{|c|c|c|c|c|c|}
\hline \multirow[t]{2}{*}{ Year } & \multicolumn{2}{|r|}{ Total } & \multicolumn{3}{|c|}{ Community-owned and managed } \\
\hline & Scheme & Generation & Scheme & Generation & H ouseholds \\
\hline & (No.) & $(\mathrm{kW})$ & (No.) & $(\mathrm{kW})$ & benefited \\
\hline Up to 1994 & 310 & 2010.0 & 2 & 150.0 & - \\
\hline 1995 & 128 & 316.2 & 9 & 95.5 & - \\
\hline 1996 & 144 & 377.5 & 11 & 136.2 & - \\
\hline 1997 & 100 & 406.1 & 11 & 166.2 & - \\
\hline 1998 & 125 & 615.5 & 21 & 313.5 & 1040 \\
\hline 1999 & 148 & 613.0 & 21 & 325.5 & 2432 \\
\hline 2000 & 152 & 933.0 & 39 & 667.6 & 2409 \\
\hline 2001 & 86 & 972.2 & 44 & 618.5 & 4118 \\
\hline 2002 & 95 & 505.0 & 66 & 486.1 & 4340 \\
\hline 2003 & 133 & 934.0 & 116 & 925.9 & 7871 \\
\hline 2004 & 101 & 561.6 & 65 & 388.0 & 3560 \\
\hline 2005 & 67 & 585.5 & 38 & 407.3 & 2972 \\
\hline Total & 1589 & 8829.6 & 443 & 4680 & 28742 \\
\hline
\end{tabular}

Source: MOEST/ AEPC, 2005 
ices. The infrastructure sub-projects of choice include micro-irrigation, villagelink roads, culverts, bridges, micro-hydroelectricity systems, water supply, sanitation, and extension/ rehabilitation of school and health post buildings.

\section{COMMUNITY PARTICIPATION}

Social mobilisation and community participation are emerging as the most-conflict resistant models of development in $\mathrm{N}$ epal. There is now evidence suggesting that development activities, which are demand-driven and have the community participation are acceptable even to the parties in conflict. Community participation isvery high in infrastructure programmes, including hydroelectricity (including micro-hydro), roads and drinking water. Such infrastructures benefit entire communitiesand can bedesigned to accommodate the needs of people from poor and excluded groups.

\section{Box 10: Kara Irrigation Project, Dang}

The K ara irrigation scheme was planned in 1995 but construction began only in 2005 . The project follows the agency/CBO model - the project was identified jointly by theagency and the users and is being built by the agency with users contributing the labour. The project aimsto irrigate6,520 ha. of land in two municipal wards and nine VDCs.

Thecanal isto be about $16 \mathrm{~km}$. long and will havea 1.2 meter span. The total estimated cost is Rs. 9.9 million where the government is contributing Rs. 9.4 million. The community contribution is Rs. 500,000 (5\% cash and remaining Rs. 407,000 as (abour). A management committee oversees project implementation.

TheWater U sers G roup (WU G) comprises 11 members including one woman. Two WUG members were selected from the two municipal wards and the remaining from the nine VDCs. A local contractor is building the project funded by the Mid-western Irrigation Division O fficeand theWU G supervises the construction. The WUG also mobilises labour contributions when needed.

R ural micro-hydro project: Thegovernment has been promoting community participation in rural electrification through micro-hydro schemes. As of thefirst half of 2005, community-run micro-hydrosweregenerating 8,830 $\mathrm{kW}$ of electricity through 1,589 projects. The projects and number of beneficiaries have been increasing every year. There were 443 community-run and managed micro-hydro projects in 2005, up from two in 1994. In all 28,742 households were benefiting from these schemes in 2005. Communities contribute 60 percent of the cost (in cash and kind) for building micro-hydros and thegovernment provides theremaining 40 percent as subsidy. Thenumber of community-managed schemes has increased after 2001. 
I rrigation: The participation model also extends to irrigation. The Irrigation Policy (2003) aimsat increasing user participation at all levels- from development, including project identification, design, and construction to operation and management. The policy also seeks to tranffer operation and maintenance of small and medium irrigation systems to user groups (Box 11). Firm data arenot availablebut government etimates suggest that farmer groupshaverepaired and maintained canalsirrigating about 12,500 ha. in thethrey

$\mathrm{H}$ eal th: Community management of health facilities was extended to 28 districts in 2004/05. The total health institutions handed over to communities for management reached 1,412 by the end of 2004/ 05, including 1,303 sub-health posts, 77 health posts and 32 primary healthcare centres. The gover nment's main strategy is to hand over the management of health services to promote community ownership and oversight. $\mathrm{N}$ epal does not have elected bodies since July 2002, and therefore, the reform has been limited to handing health facilities over to local $\mathrm{H}$ ealth Management Committees (H M C). N onetheless, this arrangement has increased community oversight.

The handover of service outlets to community management demands more participation from H MC membersin particular and the peoplein genera. In many cases community-managed health facilities have been instrumental in diversifying services. O nesuch caseis the SudaSH P in K anchanpur district (Box 12).

Community involvement has also been very encouraging in the Community $\mathrm{H}$ ealth InsuranceScheme. In 2004/ 05, theM O H P expanded the programme in six districts: $U$ rlabari of M orang, $C$ handraN igahapur of R autahat, $G$ aighat 
of $U$ dayapur, Damkaulli of $\mathrm{N}$ awal parasi, Tikapur of $K$ ailali, and Lamahi of Dang district.

The government has also expanded the Community DrugProgrammeto 25 districts. Under the programme it provides seed money for procuring essential drugsto which the community also contributes. The number of peoplevisitingtheSH Pshasin-

creased after the implementation of the programme. Generally, the serviceseekers ben efit because they are ableto purchase drugs at rates cheaper than themarket and community management of the scheme ensuresthat theservice is al ways available.

Drinking water: Community participation has been exemplary in rural drinkingwater projects. All themajor projects in the sector - theC ommunitybased Water Supply and Sanitation project, Small Town Water Supply and Sanitation Sector Project, and Rural Water Supply and Sanitation D evelopment Board - focus on a demand-driven, participatory cost-sharing approach. The projects are implemented by N GO sand CBO s (A nnex 6.4, 6.5 and 6.6).

The government's efforts to continue development activities during the conflict have had a positive impact. H owever, the programmes benefit small population groups and therefore, have to be replicated and scaled up for greater impact. These measures are only stop-gap and therefore, do not provide an alternative to peaceful conflict resolution, because only then can $N$ epal implement the Tenth Plan with the zeal and in the scale needed to attain the poverty reduction objectives. There is also no doubt that stability in $\mathrm{N}$ epal hinges on the state's ability to instituteinclusion at all levels, which is a pre-requisitefor lasting peace. H owever, in theevent the conflict prolongs, thereisno alternative but to continuewith thespecial programmes, if only as a measure to make it easier for the poor to cope with the disruptions. 


\section{Poverty Reduction Strategy Monitoring}

\section{Overview}

The $\mathrm{N}$ ational Planning Commission (N PC) began putting in place a comprehensive Poverty Monitoring and Analysis System (PM A S) in 2004. The PMAS has a set of intermediate and final indicators for effective monitoringand reportingannual progresson theimplementation of theTenth Plan/ PR SP. D ifferent monitoring and reporting tools and processes havebeen developed, field-tested and disseminated to facilitatethemonitoring of inputs, outputs and outcomes/impacts. Periodic national surveys have also been streamlined for providing coherent national household-level data. A longside the PMAS, the government has also expanded N epal Info, a database that includes both PRSP and MDG indicators and is updated annually. The most recent N epal Info datasheet contains 197 PR SP and MD G indicators.

In 2004/ 05, the N PC took further actions to develop and institutionalise the PM A Sat both the central and district levels. This included orienting officials from the N PC, CBS, and the monitoring and evaluation divisions at line ministries in participatory poverty analysisand other technical skills. Exchange visits were also organised to familiarise government officials with poverty monitoring and analysis systems abroad.

A model D istrict Poverty M onitoring and A nal ysis System (DPM A S) has al so been final ised and published. Theprocess involved stakeholder feedback from all 75 districts and some central level agencies. The development partners have shown an interest to pilot the DPMAS in 14 districts where the government isplanning full decentralisation. $O$ ver 300 officialsfrom theN PC, line ministries and N GO shave been briefed on the indicators on N epal Info, starting in 2004. Theannual PRS report drawsinformation from all of these databases, MIS data of sectoral ministries and also the various monitoring and evaluation studies conducted by the N PC and other stakeholders. 


\section{Poverty Monitoring and Analysis System (PMAS)}

The main objective of the PMAS is to coordinate, consolidate, harmonise and analyse data from existing poverty monitoring systemsand communicate results in a manner that feedback and continuously help to refine the policy process. The PM A S has the following five components or functions:

- Implementation (or input/ output) monitoring,

- Outcomeor well-being monitoring,

- Impact assessment,

- Poverty management information system, and

- Communication/advocacy.

I mplementation monitoring: Implementation monitoring reliesprimarily on input, process and output indicators. This involves monitoring of budget allocation, process/activity of policies and programmes, and the achievement of output targets of thePRSP policies and programmes. The government has been monitoring the performance of $\mathrm{P} 1$ projects and has tied budget release with performance. Sample expenditure tracking surveys are also performed annually to track budget allocation and use by different programmes. So far such tracking has been done in the education, health and transport sectors. A monitoring mechanism for tracking public expenditure and service delivery has al so been devel oped. Thetrackingwas piloted in two Targeted Programmes in 2004, and one the Women D evelopment Programme in 2005.

O utcome monitoring: 0 utcomemonitoring tracks changes in overall wellbeing or impacts over time. The goal is not to attribute outcomes to specific programmes or policies but to focus on impact indicators, or a subset of closely related indicators. The PM AS tracks both the intermediate and outcome indicators. In order to generate data for outcome monitoring, the government has begun to rely on theN epal Living Standards Survey (N LSS) and the $\mathrm{N}$ epal Demographic and $\mathrm{H}$ ealth Survey (N DH S) conducted at five year intervals for household data. The N LSS and N D H S produce data for most of the socio-economic indicators. In order to generate datato meet the PM A S requirements, additional questions relating to literacy and education are also being incorporated in the N D H S 2006.

I mpact assessment: I mpact analysis establisheslinkages between input/ output and outcomes/ impacts of a programme/ project. Impact anal ysishastwo main objectives: (i) assess the effect of aspecific policy, programme/ project on poverty 
or some other well-being outcome, and (ii) assess the efficiency of different policies/ programmesin achieving a given well-being outcome.

In 2005, the government assessed the impact of the H LFFDP - a major poverty alleviation programme. The HLFFDP, supported by IFAD, covers 26 districts. The project, underway since 1992/ 93, has two main objectives maintaining ecological balance and improving living standards of the poor by offering them degraded for est land on long-term lease. The D epartment of Forest, D epartment of Livestock Ser vices, $N$ ational A griculture Research Council and the Agricultural D evelopment Bank $\mathrm{N}$ epal implement theproject. The impact evaluation covered 10 of 26 project districts (Box 5).

\section{PARTICIPATORY MONITORING}

Participatory monitoring complements infor mation generated by thePMAS. The participatory monitoring tools used include citizens' report cards, social audits, budget reviews by civil society groups and parliamentary reviews of programme and policy performance.

The government has developed a Participatory Poverty M onitoring (PPM) mechanism for institutionalising participatory monitoring. The PPM has outlined several tools and detailsthe process of two tools, theC itizen Report Card (CRC) and Participatory Poverty A ssessment (PPA). The CRC is a monitoring instrument that measures service delivery and the PPA has been designed to serve both planning and monitoring purposes. The PPA is expected to assist the formulation of the Eleventh Plan.

The CRC has been piloted to monitor government services in 10 areas including schools, health, vital registration and land revenue collection. The service delivery was assessed by collecting feedback from the peopleon seven areas including awareness, access and sustainability of the services. Some of the findings are given in Box 13.

\section{Poverty Management Information System (PMIS)}

ThePM A S envisages that data generated through variousmonitoring efforts including thesectoral MIS and surveysis "warehoused" in a central repository. $U$ ntil that is done, the $\mathrm{N}$ epal Info at the CBS serves the purpose by bringing together data on PRSP and M D G indicators. N epal Info is updated annually. 


\section{Box 13: The people speak}

Differ ent participatory monitoring methods, including household surveysand focus group discussions, were used to collect information for theCRC. The sur veywas conducted in two districts, Rasuwa and Kanchanpur, in December 2005. The survey covered 200 households of K anchanpur and 75 households of R asuwa district. Q uestionnaire and checklists were developed to cover seven themes and the status of service delivery was assessed in 10 areas/ sectors. Theinformation from the survey and focus group discussion was then compiled to produce a compact C RC. Some findings were:

- The communities rated the importance of the 10 sectors in the following order: local heal th services, primary education, vital registration, land tax, electricity, livestock services, citizenship, agriculture services, drinking water and forest.

- O ut of the seven themes on which people's perception were scored, awareness was rated as the highest across all sectors. The rating of all other themes was in the following order: inclusion, access, attitudeand behaviour, cost, quality and timeliness, accountability and sustainability. Thisindicatesthat awareness of government services is high.

- Inter estingly, the rating of inclusion and access at second and third positions also implied that exclusion in government-provided servicesisnot as high as it is perceived to be. Thefindingswereal so supported by infor mation from focus group discussions among the different social groups including women, D alits and J anajatis.

- However, accountability and sustainability had the lowest ratings, suggesting that greater focus was needed for making government staff more accountable, and to make the services sustainable.

Source NPC, $2005_{f}$

Its latest version N epal Info 3, released in mid-2005, has information on 197 indicators. The government has plans to further expand the information database with additional poverty-related indicators.

\section{District Poverty Monitoring and Analysis System (DPMAS)}

The DPM A S was drafted in 2003. It was shared with all 75 DDC $s$ at four regional workshops and with some central-level stakeholders, including M inistry of Local Development (MLD) and A ssociation of District D evelopment Committees of $\mathrm{N}$ epal (ADDCN), in 2004. The DPM AS was refined based on the feedback and was finalised and published in $\mathrm{N}$ epali in June 2005. Fiveregional workshops were held to disseminate the DPMAS. 


\section{Results-based Management and Monitoring}

N epal has adopted a R esults-Based M anagement (RBM ) approach to improve development effectiveness. RBM isamanagement tool that providesacoherent framework for planning, implementing, monitoring and learning by shifting attention from inputs and activities to results and impacts. It emphasises effective service delivery, transparency and participation. Simultaneously, it builds on clarity of goals and objectives; systems aiming to provide measures of performance and results; a learning culture grounded in evaluation; beneficiary participation at all stages of programmedesign and implementation; clear accountabilitiesin adecentral ised framework; and linksbetween planning, resource allocation and results. 



\section{Resource Needs and Aid Harmonisation}

The G ross D omestic Product (GDP) grew by three percent (average) during the first three years of Tenth Plan. The growth was below the PRS "lower case" target of 4.3 percent. Government spending on development was al so 9.7 percent less than thetarget. R evenue rose significantly during this period, but most of theincrease went to finance the sal ary of government employees and the security bill. Foreign assistance made up about 58 percent of thetotal allocation for development programmes in 2004/ 05. The grant component of foreign aid rose significantly in 2002/ 03 but has stabilised. Total foreign assistance - both grants and loans - added up to Rs. 19.9 billion.

\begin{tabular}{|c|c|c|c|c|c|}
\hline Table 11.1: & ncome & da exp & & & (Rs. '000 \\
\hline & $2000 / 01$ & $2001 / 02$ & $2002 / 03$ & $2003 / 04$ & $2004 / 05$ \\
\hline & Actual & Actual & Actual & Actual & Revised \\
\hline Total expenditure & $79,835,097$ & $80,072,290$ & $84,006,081$ & $89,442,593$ & $100,937,300$ \\
\hline Regular & $42,769,195$ & $48,590,047$ & $54,973,061$ & $58,451,621$ & $66,552,300^{*}$ \\
\hline Development & $37,065,902$ & $31,482,243$ & $29,033,019$ & $30,990,971$ & $34,385,000^{*}$ \\
\hline $\begin{array}{l}\text { Financing sources } \\
\text { (Excluding domestic } \\
\text { borrowings) }\end{array}$ & & & & & \\
\hline Revenue & $48,893,561$ & $50,445,491$ & $56,229,790$ & $62,331,027$ & $71,332,200$ \\
\hline Foreign grant & $6,753,425$ & $6,686,139$ & $11,339,146$ & $11,283,395$ & $11,170,000$ \\
\hline Foreign loan & $12,044,026$ & $7,698,708$ & $4,546,423$ & $7,628,998$ & $8,814,000$ \\
\hline
\end{tabular}

A dequacy of aid: A dequacy of aid is not theissuein $\mathrm{N}$ epal. H owever, what is an issueis the low absorption of availableaid, especially after the escalation of the conflict, and slow disbursement in donor-funded projects. $\mathrm{N}$ epal has been under tremendous pressure for funding competing priorities, despite remarkable growth in revenue collection. The government is, therefore, in need of assistance that is both flexible and quickly available, especially for funding programmes that seek to produce quick results. D isbursement of 
some project loans was stalled in 2005, which added to the fiscal pressures. $\mathrm{N}$ epal's debt ser vicing obligationsareal so growing with thematurity of more loans.

A id effectiveness: Improving aid effectiveness is another concern. N epal has made some progress in aid coordination and har monisation at theoverall programme, sectoral and financial management levels. The harmonisation has been made possibleby clear plans, management tools and action strategies (PRSP, IA Ps, MTEF, sectoral business plans, joint portfolio performance review, PRS monitoring, and Financial Management Information System). There are several programmes in selected sectors that have common operational and financial modalitiesand arejointly funded by multipledonors. Two SWA ps are underway in the education and health sectors and common financing and project operation modalities are being prepared in the water supply and local development sectors. These activities are expected to better align aid with national priorities, systems and processes and help to reduce reporting and other transaction costs. The political situation after February 2005 resulted in disruptions in aid flows and management. The resulting unpredictability also affected development planning and execution. 


\section{Section XII}

\section{Conclusions}

Many conclusions of the second PRS progress report are relevant in the third year also, because there has been no major shift in the overall development strategy. Thesituation on theground also remained unchanged because the conflict continued throughout 2004/05. The political situation took a turn in February 2005, following which several donors suspended funding for some on-going programmes.

A chi ev ements: O verall, the achievements in the third year of the Tenth Plan/ PR SP implementation were satisfactory, given the difficult development environment resulting from the violent conflict and continued political instability. N epal's macro-level indicators remain stable, despite growing pressure on the government budget. D evelopment spending remained low, and ironically, provided a cushion to the growing demands for recurrent expenditures, including the costs of maintaining security. The government remains fully committed to take all necessary measures to maintain macroeconomic stability.

Thegovernment hasbroadened and deepened many of thereformsassociated with the Tenth Plan/ PRSP. It was necessary for protecting the gains of the past and for preventing a possiblereversal. Thereis no doubt that $\mathrm{N}$ epal has to continue with bolder refor ms and development measures but that would be possible only in an environment conducive to development work.

Nepal has little choice but to continue the policy and development management reforms for enhancing development effectiveness because otherwise, the inequalities that are there in $\mathrm{N}$ epali society will continue to grow and fuel conflict. Continued conflict could cause greater damages on development infrastructures depriving more people - and mainly the poor and excluded - of basic services, and further delay the recovery and reconstruction.

Conflict and dev el opment: Conflict resolution hasto bematched by quickyielding, inclusive development and reconstruction programmes in order to ensure lasting peace. Ther efor ms in public service deliverywould have to be 
scaled up through new measures that would put people in charge of their own development. In policy ter $\mathrm{ms}$, this means devolving and decentralising more and more tasks and functions to local bodies and community organisations in order to encourage the widest possible participation of stakeholders in all stages of programme implementation. The role of the government isalso changing from that of implementer to that of a facilitator.

The government acknowledges that there are gaps between what has been planned and the achievements, but the story-line remains unchanged: The government is pursuing social and economic refor ms in accordance with its commitments in the Tenth Plan. $\mathrm{N}$ epal's development partners can help this process by stepping back and letting the government take full charge of the development process. The donors can al so help the process by finding ways to make aid flows more predictable and readily available for addressing the fast-changing needs on the ground, while also moving towards aid harmonisation.

Restoring peace and an environment favourable for full participation by all stakeholdersisurgent, especially in thecontext of devolution of management of basic services to communities for bringing greater efficiencies in rural education, health care, agriculture and livestock extension services and for building rural infrastructures. $\mathrm{N}$ epal also needs to begin planning eventual reconstruction, and rehabilitation of people affected by theconflict, in order to be able to quickly respond to the situation when peace is established. 


\section{REFERENCES}

ARD/CMS/ICON . (2003). Final Report of N epal Community-based Water Supply and Sanitation Project Preparation Technical A ssistance.

CBS. (1996). N epal Living Standard Survey 1995/96. Kathmandu: Central Bureau of Statistics.

(2004). N epal Living Standard Survey 2003/04. Kathmandu: Central Bureau of Statistics.

(2005). Poverty Trends in N epal (1995/ 96 - 2003/ 04). Kathmandu:

Central Bureau of Statistics.

(2005 $)$. N ational A ccounts. December, 2005.

(2006). N ational A ccounts. May, 2006.

CIAA. (2005). Annual Progress Report.

DOE. (2004). Status Report of BPEBII and Education for All. Bhaktapur:

D epartment of Education.

K antipur Daily. (2005). "Community Transforms H ospital." M arch 6, 2005.

K athmandu: Kantipur

Ligal etal. (2004). Diversification of H ealth Services.

MOAC. (2005). Annual Progress Report

M OES. (2005). Education Management Information System. Kathmandu: M inistry of Education and Sports.

M OEST / A EPC . (2005). Micro-H ydro Year Book. Kathmandu: Ministry of

Environment, Science and Technology and Alternative Energy

Promotion Centre.

MOF. (2005). Annual Budget (Red Book). K athmandu: Ministry of Finance. $\left(2005_{b}\right)$. Economic Survey. K athmandu: M inistry of Finance.

MOGA. (2005). Progress of Civil Service Reform.

M OH P. (2005). H ealth M anagement Information System. K athmandu:

M inistry of $\mathrm{H}$ ealth and Population. 
MOPPW. (2004). Annual Progress Review.

NPC . (2002). Tenth Plan. K athmandu: N ational Planning Commission.

(2003). Poverty Reduction Strategy Paper. Kathmandu: N ational Planning Commission.

(2003 $)$. M edium Term Expenditure F ramework. K athmandu: N ational Planning Commission.

(2004). M edium Term Expenditure Framework. K athmandu: $N$ ational Planning Commission.

$\left(2004_{b}\right)$. First PR SP Progress Report. K athmandu: N ational Planning Commission.

(2004). Process M onitoring of Targeted Programmes: Free Text Book

Distribution and $\mathrm{N}$ ational Scholarship Programmesin D oti and Banke

District.

(2004 $)$. Poverty M onitoring and Analysis Framework. K athmandu:

$\mathrm{N}$ ational Planning Commission.

(2005). M edium Term Expenditure F ramework. K athmandu: $\mathrm{N}$ ational

Planning Commission.

(2005). Annual Development Programme (Red Book, Part 1).

$\mathrm{K}$ athmandu: $\mathrm{N}$ ational Planning Commission.

(2005). Second PR SP Progress R eport. K athmandu: N ational Planning

Commission.

(2005 $)$. Impact Evaluation of H LFFDP.

(2005). M onitoring of Women D evelopment Programme.

$\left(2005_{f}\right)$. A ssessment of Delivery of G overnment Services.

(2005). District Poverty Monitoring and A nalysis Framework. $\mathrm{K}$ athmandu: $\mathrm{N}$ ational Planning Commission.

N PC/U N DP. (2004). A ttaining M D Gs: A N eeds A ssessment Study for N epal (2005). N epal M illennium Development Goals Progress Report.

$\mathrm{K}$ athmandu: $\mathrm{N}$ ational Planning Commission/ $\mathrm{U}$ nited $\mathrm{N}$ ations

D evelopment Programme.

N RB. (2005). M acroeconomic Indicators. K athmandu: N epal R astra Bank.

RW SSF D B. (2005). Annual Progress R eport 
UN DP. (2005). H uman Development Report. N ew York: U nited N ations D evelopment Programme.

WB/IM F. (2006). Global M onitoring Report 2006: Strengthening Mutual A ccountability - Aid, Trade and G overnance.

WB. (-). N epal D evelopment Policy R eview: Restarting G rowth and Poverty reduction. Washington $\mathrm{DC}$ : The World Bank.

_-_-_ (-). Country A ssistance Strategy: N epal 1999-2001. Washington DC: The World Bank.

WECS. (2002). N ational Water Plan. K athmandu: Water and Energy Commission Secretariat. 



$$
\text { A N NEXES }
$$





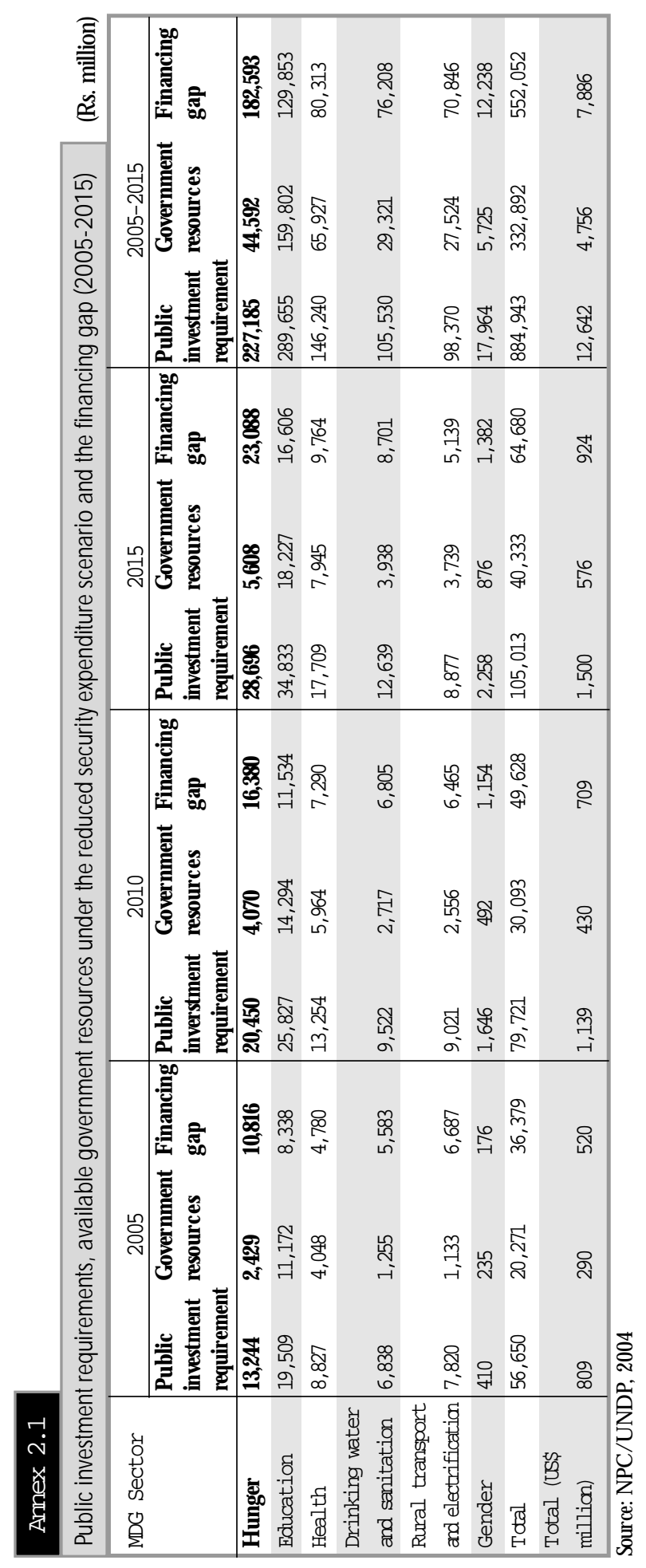




\section{Annex 4.1}

\begin{tabular}{|c|c|c|c|c|c|}
\hline & (Rs. million \\
\hline Description & $\begin{array}{r}\text { 2001/ } 02 \\
\text { Base Year }\end{array}$ & $\begin{array}{r}2002 / 03 \\
\text { Actual }\end{array}$ & $\begin{array}{r}2003 / 04 \\
\text { Actual }\end{array}$ & $\begin{array}{r}2004 / 05 \\
\text { Actual }\end{array}$ & $\begin{array}{r}2005 / 06 \\
\text { Allocation }\end{array}$ \\
\hline GDP AT CURRENT PRICE & & & & & \\
\hline GDP (at factor cost) & 406138.0 & 437546.0 & 474919.0 & 508691.0 & 551486.0 \\
\hline Agricultural GDP & 160144.0 & 171104.0 & 183117.0 & 194363.0 & 211460.0 \\
\hline N on-agricultural GDP & 245994.0 & 266442.0 & 291802.0 & 314328.0 & 340026.0 \\
\hline $\begin{array}{l}\text { GDP (at producer price) } \\
\text { GDP AT 1994/ } 95 \text { PRICE }\end{array}$ & 422807.0 & 456675.0 & 496745.0 & 533578.0 & 579787.0 \\
\hline GDP (at factor cost) & 279169.0 & 287689.0 & 298023.0 & 305232.0 & 318929.4 \\
\hline Agricultural GDP & 108752.0 & 111471.0 & 115774.0 & 119212.0 & 123980.5 \\
\hline N on-agricultural GDP & 170417.0 & 176218.0 & 182249.0 & 186020.0 & 194949.0 \\
\hline $\begin{array}{l}\text { GDP (at producer price) } \\
\text { IN VESTMENT \& SAVING }\end{array}$ & 291241.0 & 300914.0 & 312267.0 & 320717.0 & 335790.7 \\
\hline Total investment & 102174.0 & 118020.0 & 130993.0 & 137257.0 & \\
\hline Private investment & & & & & \\
\hline (including change in stock) & 70131.0 & 86792.0 & 98950.0 & 105134.0 & \\
\hline N ational saving & 69656.0 & 70972.0 & 75341.0 & 77477.0 & \\
\hline D omestic saving & 51281.0 & 54778.0 & 62386.0 & 67113.0 & \\
\hline GOVERNMENT FINANCE & & & & & \\
\hline Government revenue & 50445.5 & 56229.8 & 62331.0 & 71182.0 & 81816.6 \\
\hline Total expenditure & 80072.2 & 84006.1 & 89442.6 & 100937.3 & 126885.1 \\
\hline Regular expenditure & 48590.0 & 54973.1 & 58502.7 & 66266.5 & 74844.7 \\
\hline Development expenditure & 31482.2 & 29033.0 & 30939.9 & 34670.8 & 52040.4 \\
\hline Current expenditure & 48863.9 & 52090.0 & 55552.1 & 63117.3 & 75850.0 \\
\hline C apital expenditure & 24773.4 & 22356.1 & 23095.6 & 25165.1 & 37233.9 \\
\hline $\begin{array}{l}\text { Principal repayment } \\
\text { C apital expenditure }\end{array}$ & 6434.9 & 9559.5 & 10794.9 & 12654.8 & 13801.2 \\
\hline (incl. principal repayment) & 31208.3 & 31915.6 & 33890.5 & 37819.9 & 51035.1 \\
\hline Revenue surplus & 1855.5 & 1256.7 & 3828.3 & 4915.5 & 6971.9 \\
\hline $\begin{array}{l}\text { Government revenue-current } \\
\text { expenditure }\end{array}$ & 1581.6 & 4139 & 6778.9 & 8064.7 & 5966.6 \\
\hline Budgetary deficit & 22940.7 & 16437.2 & 15828.2 & 18585.3 & 26381.6 \\
\hline Total foreign aid & 14384.7 & 15885.5 & 18912.4 & 19984.0 & 33218.5 \\
\hline Grant & 6686.0 & 11339.1 & 11283.4 & 11170.0 & 18686.9 \\
\hline Loan & 7698.7 & 4546.4 & 7629.0 & 8814.0 & 14531.6 \\
\hline Total domestic borrowings & 15242.0 & 11890.8 & 8199.2 & 9771.3 & 11850.0 \\
\hline Domestic borrowings & 8000.0 & 8880.0 & 5607.8 & 9060.0 & 11850.0 \\
\hline $\begin{array}{l}\text { Cash balance ( - surplus) } \\
\text { M O NETARY DATA }\end{array}$ & 7242.0 & 3010.8 & 2591.4 & 711.3 & 0.0 \\
\hline ply (M 1) & 77156.2 & 83754.1 & 93969.5 & 100205.8 & 117033.0 \\
\hline Broad money supply (M 2) & 223988.3 & 245911.3 & 277305.9 & 300440.0 & 352525.0 \\
\hline Total domestic credit & 207323.0 & 228443.8 & 251088.9 & 285032.1 & 295314.0 \\
\hline $\begin{array}{l}N \text { et foreign assets } \\
\text { BALAN CE OF PAYM ENT }\end{array}$ & 88419.1 & 91407.0 & 108804.6 & 107744.4 & 129032.0 \\
\hline Exports & 46944.8 & 49930.6 & 53910.7 & 58236.2 & 59982.0 \\
\hline Imports & 107389.0 & 124352.1 & 136277.1 & 132186.8 & 142600.0 \\
\hline Current account balance & 18161.0 & 11614.7 & 14598.0 & 29243.3 & 23424.0 \\
\hline Remittances & 47536.0 & 54203.3 & 58587.6 & 65416.0 & 71858.0 \\
\hline Balance of payments (-deficit) & -3343.0 & 4363.5 & 20101.3 & 5679.4 & 6078.0 \\
\hline Gross foreign exchange reserves & 105901.0 & 108229.4 & 130205.1 & 129898.7 & 144015.0 \\
\hline
\end{tabular}

Sources CBS, 2005 and 2006; NRB, 2005; and N PC, 2005 
Annex 4.2

A. Prioritisation criteria of general administration/regular expenditure

The following criteriahave been followed in MTEF IV for prioritising general administrative or current expenditures:

a) Expenditures for providing direct services to people:

1. Citizenship certificate and passport related works

2. Primary and basic health care services

3. Land management services

4. Water supply and sanitation services

5. Communication services such as radio, television, telephone and postal services

6. Public transportation services

7. Education

8. Social security

9. Works related to providing justice

b) Expenditures for maintaining good governance:

1. Work related to promoting public accountability and transparency

2. Work related to enhance economy and efficiency in mobilizing public resources and effectiveness of government agencies

3. Work related to ensuring increased transpar ency and clarity in administrative, financial and managerial procedures

4. Work that support maintaining rule of law/ prevailing laws

5. Work related to discouraging discretionary working style

6. Work related to identifying weaknesses and suggesting practical measures on the existing procedure, working modalities and legal system

7. Work related on rewarding good governance and actions against wrongdoers including corruption control

8. Work related to maintaining law and order

c) Contribution to raising revenue:

1. O ffices collecting tax revenues

2. Work related to collecting non-tax revenues

d) Contribution to developmental work:

1. Work of institutions/ agencies contributing to poverty alleviation

2. Work of institutions/ agencies involved in rural developmental work

3. Work of institutions/ agencies involved in infrastructure development

4. Work related to tourism promotion

5. Work related to industrial services

e) O thers - human resource dev elopment, environmental conservation, regional balance, etc.

1. Work related to increasing people's participation in development, management and conservation of land and forest resources

2. Work related to the conservation of environment, biological diversity, historical diversity, flora and fauna 
cont'd...

3. Work providing benefits to local people from biodiversity and tourism development.

4. Work related to scientific exploration, excavation, research, analysis, conservation, promotion, and publication of historical, cultural and archaeological heritage

5. Training and capacity building

6. Work related conserving and promoting $N$ epali culture and state, including those of ethnic and linguistic groups, in thenational and international arenas

N ote: Under Priority 1 up to $80 \%$ of thebudget can beproposed. Ther et ar etobeinduded under second and third priority. How ever, this pr ovision will not apply to agencieswith singlebudgetsub-heading.

B. Prioritisation criteria of development expenditure

Following are the criteria used for classification of development expenditures in MTEF IV:

1. Contribution to fulfilment of national goal of poverty alleviation (20 points)

2. Contribution to sectoral goals/ objectives (15 points)

3. Contribution to regional balance(10 points)

4. Role of the government (10 points)

5. Participation (20 points)

- Peoples' or civil society participation

- Local bodies' participation

- Participation of organizations (public enter prises, autonomous bodies, etc.)

- Enhancement of the private sector

6. Project status (15 points)

- $\quad$ Age of the project (to be counted from starting year)

- Previousperformance

- Completion stage

7. Certainty of funding (10 points) 


\section{Annex 6.1}

Summary of the major programmes and achievement in health - 2061/62 (2004/05)

\begin{tabular}{|c|c|c|}
\hline S.N. & Programmes & Progress/performance \\
\hline 1. & $\begin{array}{l}N \text { ational population } \\
\text { programme }\end{array}$ & $\begin{array}{l}\text { - Awareness raising activities through various media and NGOS } \\
\text { - Participatory programmes with DDC to integrate the } \\
\text { population activities with local development } \\
\text { - A dolescent population programme }\end{array}$ \\
\hline 2. & $\begin{array}{l}\text { Sukraraj Tropical and } \\
\text { Communicable D isease } \\
\text { H ospital }\end{array}$ & $\begin{array}{l}\text { - Programmes to control communicable and tropical diseases } \\
\text { - Purchase of medicines and addition of doctors' quarter }\end{array}$ \\
\hline 3. & $\begin{array}{l}\text { Family Planning and } \\
\text { Materna Child, and FCHV } \\
\text { programme }\end{array}$ & $\begin{array}{l}\text { - Awareness raising activities } \\
\text { - Treatment services } \\
\text { - Training to health personnel, including FCH V, and } \\
\text { - Promotion of FCH Vs to AN Ms }\end{array}$ \\
\hline 4. & N utrition programme & $\begin{array}{l}\text { - Awareness raising activities } \\
\text { - Vitamin 'A' distribution }\end{array}$ \\
\hline 5. & $\begin{array}{l}\text { Tuberculosis control } \\
\text { programme }\end{array}$ & $\begin{array}{l}\text { - D0 T's programme } \\
\text { - Freemedicine to patients }\end{array}$ \\
\hline 6. & $\begin{array}{l}N \text { ational A ID S and STD } \\
\text { Control programme }\end{array}$ & $\begin{array}{l}\text { - Awareness raising activities on HIV/AIDS and STDS } \\
\text { - Self-employment training to } 20 \text { H IV infected persons } \\
\text { - } \text { ARV purchase and free distribution } \\
\text { - } \text { ARV medicines to } 150 \text { persons } \\
\text { - } \text { PMICT programme in } 3 \text { hospitals }\end{array}$ \\
\hline 7. & $\begin{array}{l}\text { N ational Immunization } \\
\text { Programme }\end{array}$ & $\begin{array}{l}\text { - Polio drops to children below } 5 \text { years } \\
\text { - Immunization of morethan } 10 \text { million children } \\
\text { - Purchase of BCG vaccine, H epatitis 'B' vaccine }\end{array}$ \\
\hline 8. & $\begin{array}{l}\text { Diarrhoea and ARI Control } \\
\text { and N utrition Programme }\end{array}$ & $\begin{array}{l}\text { - Printing of mother's counselling cards, nutrition IEC material } \\
\text { - Purchase of A RI sound timer, Salter scale, A bendazol, and } \\
\text { arm measuring tape }\end{array}$ \\
\hline 9. & \begin{tabular}{|l|} 
Epidemiology, Malaria, \\
K alazazar Control and \\
Disaster Management Programme
\end{tabular} & $\begin{array}{l}\text { - Purchase, supply of snake bite venom medicine, and training } \\
\text { - Spraying (twice) in two M alaria prone districts } \\
\text { - Purchase of emergency medicines and supply in natura } \\
\text { disaster-affected districts } \\
\text { - Purchase of anti-mosquito nets }\end{array}$ \\
\hline 10 & $\begin{array}{l}\text { N ational } H \text { ealth Education, } \\
\text { Information and Publicty } \\
\text { Programme }\end{array}$ & $\begin{array}{l}\text { - Printing and distribution of IEC materials } \\
\text { - Awareness raising through radio }\end{array}$ \\
\hline 11 & $\begin{array}{l}\text { National } \mathrm{H} \text { ealth Training } \\
\text { Programme }\end{array}$ & $\begin{array}{l}\text { - Training to more than } 500 \text { health personnel } \\
\text { - Preservicetraining to more than } 100 \text { staff } \\
\text { - Supply management training to morethan } 800 \text { staff } \\
\text { - Training on capacity development, family planning, nursing } \\
\text { and management, bio-medical, and training to FCHV }\end{array}$ \\
\hline 12 & $\begin{array}{l}\text { Vector Born DiseaseC ontrol, } \\
\text { Research and Training } \\
\text { Programme }\end{array}$ & $\begin{array}{l}\text { - O rientation training on early warning reporting system } \\
\text { Distribution of test-kits against K alazazar, } \\
\text { - Research on Japanese encephalitis } \\
\text { - Training on malaria }\end{array}$ \\
\hline & $\begin{array}{l}\text { Health Social Security } \\
\text { Programme }\end{array}$ & $\begin{array}{l}\text { - Health insurance programme in three districts } \\
\text { - M obile clinics in } 19 \text { districts }\end{array}$ \\
\hline
\end{tabular}


Annex 6.2

Basic information on health facilities, 2005

$\mathrm{H}$ ealth facilities

N umber

$\mathrm{H}$ ospitals

District Public $\mathrm{H}$ ealth $\mathrm{O}$ ffices

75

Primary $\mathrm{H}$ ealth $\mathrm{C}$ are $\mathrm{C}$ entres

186

$\mathrm{H}$ ealth Posts

Sub-health Posts

3,129

$\mathrm{PHC} / \mathrm{ORCS}$

14,710

EPIClinics

16,099

FCHVs

48,164

TBAS

15,341

I/ N G O, Private H ealth F acilities

Source MOHP, 2005

\section{Annex 6.3}

\section{Fund Board target Vs progress}

\begin{tabular}{|c|c|c|c|}
\hline Particulars & $\begin{array}{l}\text { No. of } \\
\text { schemes }\end{array}$ & $\begin{array}{l}\text { Total } \\
\text { beneficiaries } \\
\text { (Population) }\end{array}$ & Remarks/ present status \\
\hline $\begin{array}{l}\text { Target for Tenth Plan } \\
\text { period }\end{array}$ & 1260 & 813,000 & \\
\hline $\begin{array}{l}\text { Progress to date: } \\
\text { Schemes completed under } \\
\text { Batch- IV }\end{array}$ & 339 & 205510 & Construction completed \\
\hline $\begin{array}{l}\text { Carried over schemes } \\
\text { of Project-I }\end{array}$ & 18 & 5580 & $\begin{array}{l}\text { Construction on-going. Expected to } \\
\text { be completed within } 2 \text { months. }\end{array}$ \\
\hline $\begin{array}{l}\text { Schemes to be completed } \\
\text { under Batch-V }\end{array}$ & 338 & 230534 & $\begin{array}{l}0 \text { ut of } 338 \text { schemes, implementation } \\
\text { phase has been started in } 241 \text { schemes. } \\
0 \text { ther schemes to enter into implementation } \\
\text { phase within two months. }\end{array}$ \\
\hline $\begin{array}{l}\text { Schemes to be completed } \\
\text { under Batch-VI }\end{array}$ & 400 & 260225 & $\begin{array}{l}\text { Feasibility study has been completed in } 443 \\
\text { schemes; of these } 400 \text { schemesare to be } \\
\text { completed within } 10^{\text {th }} \text { Plan period. }\end{array}$ \\
\hline Achievement to date & 1095 & 701849 & \\
\hline Achievement \% & 86.9 & 86.3 & \\
\hline
\end{tabular}

Source RW SSFD B, 2005

N ote: For Batch - VII Schemes Pre-development phase activities (SO Selection) ar eunderway. U nder the Tenth Plan, D evelopment Phaseactivities will becompleted in around 400 schemes of this Batch. 


\section{Annex 6.4}

\section{The Fund Board and its projects}

The Rural Water Supply and Sanitation Fund Development Board has been supporting communitiesin theimplementation of water supply and sanitation schemesthrough demandled, community-based and integrated approaches to ser vice delivery with full emphasis on community owner ship and responsibility. The board mainly implements small rural water supply schemes using simple technology (gravity-flow and ground water). However, depending on community demand and thelocal situation, it also considerswith comparatively advanced technical options (e.g. lift schemes with or without boring). These schemes need skilled human resources and close super vision, and significant resources for construction, operation and maintenance. H owever, experience of the Board shows that where there is real need for water and the beneficiaries are committed, they can build and operate even more sophisticated schemes. The Sattipipal (K arnekhola) schemein Gorkha district is one such example.

\section{Sattipipal: A community-managed double-stage pumping scheme}

The Sattipipal scheme coversward numbers 2 and 4 of thePrithvi $N$ arayan municipality of G orkha district and serves 296 households with 1,715 members. The beneficiaries come from different ethnic groupsi.e. Gurung, $\mathrm{N}$ ewar, Tamang and $\mathrm{M}$ agar. The user group also includes $17 \mathrm{D}$ al it households. The total cost of the schemewas R s. 7,744,000 of which the community contributed 25.5 percent.

The scheme is a lift system that involves two-stage pumping and was built two years ago under the Batch-IV programmes. There are 174 taps including 10 public taps (for low income groups who cannot afford private taps). All private taps are metered. An eleven member water user's committee (including 4 women) was involved in the construction of the scheme and is now responsible for its operation.

The user committee has five paid staff ( 4 technical and 1 administrative) to look after the day-to-day operations and for financing the operation costs (e.g. electricity for pump operation, office/ administrative expenses and salary of caretakers/ plumbers) from water tariffs. The user committee's monthly expense is Rs. 43,500 and it has an income of Rs. 49,500. It saves Rs. 6,000 each month which is used for operation and maintenance.

Thewater users committee meets onceevery month. It has its own office building, which is reasonably furnished. It also maintains a supply of spares.

The users have also made significant achievement towards the construction of sanitary latrines and to engage women from the community in income generation activities, under the Women Technical Support Service (WTSS) program.

(A dapted fr om theFund Board's r ecords.) 


\section{Annex 6.5}

\section{Participation of poor and disadvantaged groups in urban projects}

This case depicts how a conventional town water supply project has started paying attention to the needs of the poor with the knowledge that the cost recovery rules could deny the poor access to water supply.

Generally, the ST W SSSP aims to support about 40-50 emerging townships in water supply and sanitation. It aims to benefit about 600,000 people, of whom 34\% live below the poverty line. $\mathrm{N}$ inety-five\% of proposed investment is to be spent on water supply, on an equal community cost-sharing basis. Local contribution for public sanitation comprises $20 \%$ of thecost. Theproject provides up to $50 \%$ grantsin-kind to the very poor for building toilets at home. The government has used the services of national-level N G O s for community mobilization.

The project hopes that improved water supply and sanitation will significantly reduce the costs borne by the urban poor in ter ms of purchase, treatment and storage of water, medical expenses to treat $w$ aterborne diseases, and the time spent on fetching water. It al so provides employment opportunities for low skilled labourers.

TheST WSSSP hasmadespecial effortsto collect infor mation on poor population groupsresiding in the project towns and monitors their inclusion in the activities. This allows it to constantly assess the ability of thevery poor and excluded groupsto contributeto thecost sharing mechanisms, including their ability to repay loansobtained from theT DF. Theproject has proposed the following mechanisms for greater inclusion of excluded groups:

- U sers shall becategorized as non-poor; poor, urban poor or ultrapoor (low incomehousehold); and squatters (disadvantaged).

- Registration fees, connection charges and water tariffs will be lower for the ultra poor.

- Contribution of the 5\% up-front cash for the ultra poor may be eased by allowing them to pay in instalments, increasing number of instal ments and reducing the instalment amount.

- Building community taps for use by the poor.

- TheWSU C may opt to pay therequired up-front cash from their funds, which thevery poor may beallowed to reimburse through easy instalments.

- Savingsfrom the proposed reduction of interest ratesfrom $8 \%$, if approved, may be used to encouragetheparticipation of thevery poor. Thefund could beused for paying theup-front contributions, making up for lower registration or membership fees for them and also to cover the costs for lower connection charges they may offer to groups that cannot pay normal charges.

- Simplification of water tariffs, with lower rates for community connections.

- Theinterest earned on the amount deposited ( $5 \%$ upfront payments) may beused to facilitate payments by the poor to participate in the schemes.

- Communitiesareencouraged to seek financial help from local bodies, N G O s and IN G O sto support the very poor households.

- Charging additional tariffs to those that can pay for covering the cost of supplying water to the very poor, and

- Depending on the capability of users and the nature of work, it may also contract work to thevery poor groups to enablethem to earn money to pay for services (mainly tasks such as excavation and refilling).

These efforts, where they have been tried out, have al ready produced positive results in some subprojects. At M anipur the WSU C hastaken the following initiatives to support the very poor:

- Thevery poor were given opportunity to pay easy instalmentsfor tap connections (but they picked community taps).

- There is no connection charge for community taps.

- In order to cater to poor households, only groups of 3 or 4 households can seek a private connection, not onefor each household.

- The tariffs and connection rates are different for urban and rural residents, because most of the urban poor live in rural parts of the service area (For rural connections, the connection charge is R s. 5,000; it is Rs. 10,000 for urban connections).

- The project has provided subsidised construction material for building 225 toilets in very poor households.

(Based on infor mation provided by theD W SS.) 


\section{Annex 6.6}

\section{Water supply projects underway}

DWSS is implementing two major projects which would have far reaching implications for both the department and the sector:

The Community-based Water Supply and Sanitation Project (CWSSP) aims to provide sanitation facilities to 1,200 communities in 21 districts, including those in conflict affected areas - 12 in the Mid-west and seven in theF ar-w est. Theproject blends locally-proven best practices (demand-driven, cost-sharing, community-implemented and N G O -facilitated) into the central government and local bodies with clearly defined roles (DWSS, as executing agency, and DDCs, as supporting agencies) and a milestone-based fund flow mechanism. A nother unique project feature is the mainstreaming of gender, caste and ethnicity into implementation processthrough proportional representation in decision-making ${ }^{27}$. The project waslaunched in A pril 2004 and therecruitment of central project implementation consultants has been completed; nine DDC $\mathrm{s}^{28}$ have entered into project agreements committing themselves to contribution, staffing, auditing and reporting, which is a requirement.

TheSmall Town Water Supply and Sanitation Sector Project isa demand-driven project that includes ben eficiary ownership, cost recover ${ }^{29}$, participatory implementation and multiagency involvement. Properly implemented - the role and performance of the DWSS is crucial - the ST WSSP approach could emerge as a model for the development of water supply and sanitation in semi-urban areas. U nder theproject, 33 subprojectshave been selected for implementation using agreed screening criteria and specified procedures, and implementation of 32 subprojects is underway. Four of the first batch subprojects and five from the second batch are expected to be completed by $2005 / 06$. The project is behind schedule and also faces the issue of exclusion of the very poor. An A sian Development Bank (ADB) study to assess if the cost recovery requirement affected the participation of thepoor in the subprojects reported a general lack of "recognition of thepoor" ${ }^{30}$. Thestudy also found that the main factor responsible for the non-participation of the poor and disadvantaged was the upfront contribution of five percent initial cash and the connection cost. It has recommended that easing the upfront payment burden for the very poor would be a way to ensure them access to the services ${ }^{31}$.

The Rural Water Supply and Sanitation Fund Development Board (also known as Fund Board) is a government agency involved in community-based rural water supply and sanitation. It has completed the first phase of the World Bank-funded Rural Water Supply and Sanitation Project Phase I, and is now implementing Phasell of the project. The Fund Board has programmes in 60 districts in all five development regions. The board has been moving programmes into the conflict-affected areas and remote villages. The Fund Board has adopted a policy to only take up schemes approved in the district development plans as a strategy to involve DDCs in monitoring and post-project support It also emphasises meaningful participation of excluded groups, including women, D alits and Janajatis.

${ }^{27}$ A condition of funding a schemeisthat beneficiary communitieswill have to form water user and sanita tion committees with proportional representation of poor, D alits and ethnic minorities and with at least 50 percent women executive members.

${ }^{28}$ Includes Pyuthan, Baitadi, D adeldhura, K apilbastu, Rukum, Rolpa, Baghang and D oti.

${ }^{29}$ Water users' groups have to bear 50 percent capital cost (5\% initial cash and $15 \%$ labour/materials/ cash payment as upfront contribution, and $30 \%$ loan from T DF to be paid back as monthly tariff) and the entire cost of system operation, maintenance and expansion.

30 There has been some improvement in this respect and N G O s have identified and documented poor and ultra poor households in the subprojects.

${ }^{31}$ Small Town Water Supply and Sanitation Sector Project: Review of Project Implementation with special Reference to Exclusion. 


\section{Annex 7.1}

\begin{tabular}{|c|c|c|c|c|c|c|}
\hline \multicolumn{7}{|c|}{ List of Targeted Projects/Programmes 2003/04 - 2005/06 } \\
\hline Projects/ programmes & $\begin{array}{r}2005 / 06 \\
\text { Budget } \\
\text { Priority code }\end{array}$ & Amount & $\begin{array}{l}\text { 2004/05 } \\
\text { Revised expe } \\
\text { Priority code }\end{array}$ & $\begin{array}{l}\text { enditure } \\
\text { Amount }\end{array}$ & $\begin{array}{l}\text { 2003/04 } \\
\text { Actual expen } \\
\text { Priority code }\end{array}$ & $\begin{array}{l}\text { nditure } \\
\text { Amount }\end{array}$ \\
\hline Nepal Food Corporation & P1 & 260000 & P1 & 209923 & P1 & 188900 \\
\hline Goitre Control Project & P1 & 70000 & P1 & 50000 & P1 & 50000 \\
\hline $\begin{array}{l}\text { K arnali Zone Agriculture } \\
\text { D evelopment Project }\end{array}$ & P1 & 25525 & P1 & 73149 & P1 & 63875 \\
\hline $\begin{array}{l}\text { Rehabilitation Programme } \\
\text { Ganeshman Singh Peace } \\
\text { Campaign }\end{array}$ & P1 & 55000 & P1 & 167932 & P1 & 76097 \\
\hline $\begin{array}{l}\text { Land Reform Programme } \\
\text { and Rehabilitation of Freec } \\
\text { Bonded Labour }\end{array}$ & P1 & 61299 & P1 & 11501 & P1 & 7805 \\
\hline $\begin{array}{l}\text { Women Empowerment } \\
\text { Programme }\end{array}$ & P1 & 3684 & P1 & 21332 & P1 & 2249 \\
\hline $\begin{array}{l}\text { Social Welfare Programme } \\
\text { Including Senior Citizen } \\
\text { H ealth Programme }\end{array}$ & P1 & 7853 & P1 & 7482 & P1 & 4615 \\
\hline $\begin{array}{l}\text { Special Area D evelopment } \\
\text { Programme }\end{array}$ & $\mathrm{P} 1$ & 40000 & P1 & 46826 & P1 & 24968 \\
\hline $\begin{array}{l}\text { Jagariti - Women Income } \\
\text { Generation Programme }\end{array}$ & & & P2 & 40066 & P2 & 47408 \\
\hline $\begin{array}{l}\text { National Federation of } \\
\text { Disabled } N \text { epal - including }\end{array}$ & & & & & & \\
\hline A ssociation of Disabled & P1 & 2900 & P3 & 2469 & P1 & 2877 \\
\hline $\begin{array}{l}\text { Child Welfare Programme } \\
\text { Women D evelopment }\end{array}$ & P1 & 6612 & P1 & 5012 & P1 & 30 \\
\hline Programme & P1 & 176115 & P1 & 86440 & $\mathrm{P} 1$ & 12135 \\
\hline $\begin{array}{l}\text { Forestry Programme for } \\
\text { Livelihood }\end{array}$ & P1 & 55810 & P1 & 64784 & P1 & 108497 \\
\hline $\begin{array}{l}\text { Institutional Development } \\
\text { for N ational Volunteer } \\
\text { Services }\end{array}$ & P1 & 50200 & P1 & 19132 & P1 & 136 \\
\hline $\begin{array}{l}\text { Targeted G roup U pliftmen } \\
\text { D evelopment Committee }\end{array}$ & t 1 & 21700 & P1 & 21250 & P1 & 11167 \\
\hline $\begin{array}{l}\text { Tribal/R acial U pliftment, } \\
\text { Including Praja }\end{array}$ & P1 & 33000 & & & P1 & 21267 \\
\hline $\begin{array}{l}\text { Woollen Carpet Child Labour } \\
\text { Elimination and Child }\end{array}$ & & & & & P3 & 2449 \\
\hline $\begin{array}{l}\text { Labour Reform Project } \\
\text { Western Tarai Poverty }\end{array}$ & P2 & 84750 & P3 & 3156 & Ps & $\angle 449$ \\
\hline Alleviation Project & P1 & 16543 & P1 & 81395 & P1 & 81432 \\
\hline Western H igh H ill R egion & & & & & & \\
\hline Poverty A lleviation Project & P1 & 84186 & P1 & 48211 & P1 & 36563 \\
\hline Rural Micro Credit Project & P1 & 335800 & P1 & 185200 & P1 & 0 \\
\hline $\begin{array}{l}\text { Under Privileged Group } \\
\text { Special Programme- } \\
\text { Women, Tribal and Dalit }\end{array}$ & P1 & 40000 & P1 & 40975 & & \\
\hline Poverty Alleviation Fund & & & P1 & 83246 & P1 & 150 \\
\hline $\begin{array}{l}\text { Gender Equality and Women } \\
\text { EmpowermentProgramme }\end{array}$ & P2 & 36000 & & & P2 & 0 \\
\hline
\end{tabular}


cont'd...

\begin{tabular}{|c|c|c|c|c|c|c|}
\hline $\begin{array}{l}\text { Drug Abuse Control } \\
\text { M aster Plan }\end{array}$ & P2 & 6785 & P2 & 5476 & P2 & 4718 \\
\hline $\begin{array}{l}\text { Women D evelopment } \\
\text { Programme }\end{array}$ & P2 & 36876 & P2 & 8209 & P2 & 92705 \\
\hline $\begin{array}{l}\text { Women Skill D evelopment } \\
\text { Programme }\end{array}$ & P2 & 3000 & P2 & 4457 & P2 & 3628 \\
\hline $\begin{array}{l}\text { Food For Education } \\
\text { Programme-Primary } \\
\text { School N utritious Food }\end{array}$ & P2 & 776216 & P2 & 534552 & P2 & 380901 \\
\hline $\begin{array}{l}\text { Monastery M anagement } \\
\text { and D evelopment } \\
\text { Commission }\end{array}$ & P2 & 10000 & P2 & 7490 & & \\
\hline $\begin{array}{l}\text { Remote and Special Area } \\
\text { Development Programme }\end{array}$ & P2 & 138700 & P2 & 117760 & P2 & 121040 \\
\hline $\begin{array}{l}\text { Decentralised A ction Plan } \\
\text { for Children and Women }\end{array}$ & P2 & 215717 & P2 & 161772 & P2 & 146225 \\
\hline $\begin{array}{l}\text { Sports, Youth and Extra } \\
\text { Activities }\end{array}$ & P3 & 11500 & P3 & 2429 & P3 & 1638 \\
\hline Women Education & & & & & P1 & 126092 \\
\hline $\begin{array}{l}\text { National Scholarship } \\
\text { Programme } \\
\text { Free Text Books }\end{array}$ & & & & & $\begin{array}{l}\text { P1 } \\
\text { P1 }\end{array}$ & $\begin{array}{l}79661 \\
265014\end{array}$ \\
\hline Poverty Alleviation Fund & P1 & 508099 & & & & \\
\hline $\begin{array}{l}\text { Immediate R elief } \\
\text { Programme for Conflict } \\
\text { A ffected Child }\end{array}$ & P1 & 6000 & & & & \\
\hline $\begin{array}{l}\text { Women Self Reliance and } \\
\text { SN IP Programme } \\
\text { Fellowship for Exploited, } \\
\text { Dalit and Children of } \\
\text { Martyrs including Fund } \\
\text { for Girl Education }\end{array}$ & & & P2 & 55974 & & \\
\hline & Number & Amount & N umber & Amount & N umber & Amount \\
\hline P1 & 21 & 1860326 & 18 & 1223790 & 22 & 1163530 \\
\hline P2 & 9 & 1308044 & 10 & 945291 & 8 & 796625 \\
\hline P3 & 1 & 11500 & 3 & 8054 & 2 & 4087 \\
\hline Total & 31 & 3179870 & 31 & 2177135 & 32 & 1964242 \\
\hline
\end{tabular}

Source MOF, 2005 and NPC, 2005 


\section{Annex 10.1}

\begin{tabular}{|c|c|c|c|c|c|c|}
\hline \multicolumn{7}{|c|}{ Poverty Monitoring Key Indicators } \\
\hline \multirow{2}{*}{$\begin{array}{l}\text { Sector/ } \\
\text { theme } \\
\text { Income/ } \\
\text { consump } \\
\text { tion poverty }\end{array}$} & \multirow{2}{*}{\begin{tabular}{|l|}
$\begin{array}{l}\text { O utcome/ impact } \\
\text { indicators }\end{array}$ \\
$\begin{array}{l}\text { Population below } \\
\text { poverty line }\end{array}$ \\
\end{tabular}} & \multirow{2}{*}{$\begin{array}{l}\text { Inter mediate indicators } \\
\text { - Percentage of population below } \\
\text { poverty line } \\
\text { - Share of poorest quintile in national } \\
\text { consumption } \\
\text { - Gini coefficient }\end{array}$} & \multicolumn{4}{|c|}{ Fiscal Year } \\
\hline & & & $\begin{array}{r}2001 / 02 \\
38\end{array}$ & $2002 / 03$ & $\begin{array}{r}2003 / 04 \\
30.85\end{array}$ & $2004 / 05$ \\
\hline \multirow{4}{*}{$\begin{array}{l}\text { Economic } \\
\text { growth }\end{array}$} & Faster Economic & - Overall GDP growth (real) \% p.a & -0.6 & 3.1 & 3.6 & 2.4 \\
\hline & Growth & - Agriculture $\quad$ (real) \% p.a. & 2.2 & 2.5 & 3.9 & 3.0 \\
\hline & & - N on-agriculture (real) \% p.a & -1.9 & 3.4 & 3.4 & 2.1 \\
\hline & & - Per capita incomegrowth (real) \% p.a. & -2.8 & 1.0 & 1.3 & 0.3 \\
\hline \multirow{2}{*}{$\begin{array}{l}\text { Macro } \\
\text { economic }\end{array}$} & Fiscal Balance & - Revenue/ GDP ratio (\%) & 11.9 & 12.3 & 12.6 & 13.5 \\
\hline & & $\begin{array}{l}\text { - Development Exp./ Total Exp. } \\
\text { ratio (\%) }\end{array}$ & 39.4 & 34.4 & 25.8 & 24.9 \\
\hline \multirow[t]{24}{*}{ stability } & & - Regular expenditure/ GDP ratio (\%) & 11.5 & 12.1 & 12.6 & 12.4 \\
\hline & & - Development Exp. / GDP ratio (\%) & 6.4 & 6.4 & 4.7 & 4.8 \\
\hline & & - Domestic borrowing/GDP ratio (\%) & 3.6 & 2.6 & 1.7 & 1.6 \\
\hline & Balance of & - Exports/GDP ratio (\%) & 11.1 & 11.0 & 10.7 & 11.0 \\
\hline & payments & - Workers remittances/ GDP (\%) & 11.3 & 11.9 & 12.6 & 12.4 \\
\hline & & - Gross reserves (Rs, billion) & 105.9 & 108.2 & 130.2 & 129.9 \\
\hline & & - Current account balance (Rs. billion) & 18.16 & 11.61 & 14.6 & 29.2 \\
\hline & Monetary stability & - Broad money growth (\%) p.a. & 4.5 & 9.8 & 11.8 & 12.0 \\
\hline & & - Domestic credit growth (\%) p.a. & 10.4 & 10.2 & 9.5 & 14.2 \\
\hline & Inflation & - Consumer prices (\%) p.a. & 2.9 & 4.8 & 4.1 & 4.5 \\
\hline & Efficiency of public & - Prioritisation (P1, $\mathrm{P} 2, \mathrm{P} 3)$ in place $(\%)$ & NS & $\mathrm{P} 1=59$ & $\mathrm{P} 1=72.5$ & $P 1=76.1$ \\
\hline & spending & & & $P 2=33$ & $P 2=23.3$ & $P 2=21.2$ \\
\hline & & & & $\mathrm{P} 3=8$ & $P 3=4.2$ & $P 3=2.7$ \\
\hline & & $\begin{array}{l}\text { - Budget release to } \mathrm{P} 1 \text { against } \\
\text { allocation to } \mathrm{P} 1(\%) \\
\text { - Trimester reporting of outputs for }\end{array}$ & NS & 73 & 91 & 100 \\
\hline & & $\begin{array}{l}\text { P1 projects done for every trimester } \\
\text { - N umber of enterprises }\end{array}$ & $\checkmark$ & $\checkmark$ & $\checkmark$ & $\checkmark$ \\
\hline & & privatised/ liquidated & 1 & 7 & 1 & 1 compl \\
\hline & & & & & & 7 under \\
\hline & & - Proportion of pro-poor spending & & & & way \\
\hline & & to total spending $(\%)$ & 27.1 & - & - & 31.1 \\
\hline & Health of financial & - Capital adequacy ratio & 12 & 11 & 11 & 11 \\
\hline & sector institutions & - N on-performing assets ratio & 30.4 & 28.8 & 28.9 & \\
\hline & & $\begin{array}{l}\text { - Completion of on-site inspection } \\
\text { (number) of commercial banks }\end{array}$ & & & & \\
\hline & & - Corporate Level & 7 & 7 & 9 & 15 \\
\hline & & - Branch Level & 30 & 26 & 24 & 9 \\
\hline \multirow[t]{4}{*}{ Agriculture } & Food security & - N umber of districts served by NFC & 32 & 31 & 30 & 30 \\
\hline & & - Q uantity of food sold (tons) & 8,213 & 5,693 & 6,100 & 5882 \\
\hline & Overall agriculture & - Length of rural roads $(\mathrm{km})$ & 2,361 & 905 & 840 & 934 \\
\hline & growth & - N umber of VDC s electrified & 1,600 & 1,800 & 2,000 & 2,200 \\
\hline
\end{tabular}




\begin{tabular}{|c|c|c|c|c|c|c|}
\hline & & $\begin{array}{l}\text { - N umber of public market collection } \\
\text { centres/ market yards } \\
\text { - Agricultural credit (ADB/N only, } \\
\text { Rs in million) } \\
\text { - Area under irrigation (ha.) } \\
\text { - U se of chemical fertiliser (mt.) }\end{array}$ & $\begin{array}{r}31 \\
7,110 \\
\\
937,722 \\
193,154\end{array}$ & $\begin{array}{r}33 \\
7,669 \\
\\
985,546 \\
172,270\end{array}$ & \begin{tabular}{r|r}
750 \\
10,151 \\
\\
$1,128,000$ \\
161,316
\end{tabular} & 10,432 \\
\hline & Crop production & - N umber of functioning farmers groups & 7,508 & 9,383 & $\begin{array}{ll}3 & 11,272\end{array}$ & 13,118 \\
\hline & & - Improved seeds (mt.) & 2,654 & 2,574 & 5,751 & 2,824 \\
\hline & & - N umber of pocket programmes & 1,897 & 1,967 & 1,967 & 2,509 \\
\hline & & - Crop/ horticulture credit (Rs.million) & 2,028 & 2,222 & 2,024 & 2,031 \\
\hline & Livestock & - N umber of livestock farmers groups & 6,623 & 6,954 & 6,965 & 7,543 \\
\hline & production & - N umber of Artificially Inseminated (AI) & 53,641 & 52,049 & 44,344 & 46,434 \\
\hline & & - Production of milk (mt) & $1,158,780$ & $1,195,931$ & $1,238,000$ & $1,274,000$ \\
\hline & & - N umbers of pocket programmers & & & & \\
\hline & & - Livestock credit (Rsmillion) & 1,570 & 1,634 & 1,597 & 1,844 \\
\hline & & - M eat/ Egg production (mt.) & 737,060 & 761,250 & 783,760 & 590,131 \\
\hline Irrigation & $\begin{array}{l}\text { A reaunder year } \\
\text { round irrigation }\end{array}$ & $\begin{array}{l}\text { - N umber and hectare of STW, DTW } \\
\text {-STW }\end{array}$ & $-/ 9,969$ & $657 / 1905$ & $1,430 / 485$ & $2,397 / 7572$ \\
\hline & & $\begin{array}{l}\text {-DTW } \\
\text { - Surface irrigation schemes with }\end{array}$ & $-29,586$ & $44 / 1592$ & \begin{tabular}{l|l}
$58 / 320$ \\
\end{tabular} & $10 / 385$ \\
\hline & & & & $16 / 3,071$ & $17 / 6,851$ & $10 / 2,556$ \\
\hline & & - Area under year round irrigation(ha.) & & & 465,402 & 474,381 \\
\hline & $\begin{array}{l}\text { Management } \\
\text { transfer to WUAs. }\end{array}$ & $\begin{array}{l}\text { - N umber of rehabilitated and handed } \\
\text { over schemes }\end{array}$ & 5 & 50 & & 29 \\
\hline Power & Percentage of & - Installed capacity(mw) & 584 & 606 & 609 & 613 \\
\hline & population with & - Percentage of system losses(\%) & 24.6 & 23.6 & 22.9 & 24.83 \\
\hline & ecectricity services & - H ouseholds electrified(\%) & 40 & 43 & 48 & 49 \\
\hline & Increased rurd & - Per capita rural electricity consumption & & & - & \\
\hline Forestry & A rea under intense & - Area under community forest (ha.) & $1,028,473$ & $\begin{array}{r}1,000 \\
1,062,823\end{array}$ & 2,000 & $1,170,896$ \\
\hline $\begin{array}{l}\text { and soil } \\
\text { conservation }\end{array}$ & forest coverage & $\begin{array}{l}\text { - A rea under leasehold forest (ha.) } \\
\text { - N umber of households under }\end{array}$ & 4,378 & 7,061 & - & 9,838 \\
\hline & & $\begin{array}{l}\text { leasehold forest } \\
\text { - Area under national parks/protected }\end{array}$ & 9,070 & 10,027 & & 15,122 \\
\hline & & area (\%of total land) & 18 & 18.3 & 18.3 & 18.6 \\
\hline & & shrub land (\%) & 39.6 & 39.6 & 39.6 & 39.6 \\
\hline & $\begin{array}{l}\text { Incomefrom } \\
\text { forestry }\end{array}$ & $\begin{array}{l}\text { - Income generated by FUGs (CFUGs } \\
\text { only; Rs in million) }\end{array}$ & 129 & 124 & - & NA \\
\hline Industry, & Expansion of & - Growth rate (\%) p.a. - Industry & -2.9 & 2.2 & 1.8 & 0.7 \\
\hline Trade and & industrial & - Services & -1.3 & 3.1 & 4.2 & 2.1 \\
\hline Tourism & production & - Share in GDP ～- Insdustry & 22.8 & 22.7 & 22.3 & 22.2 \\
\hline & & $\begin{array}{c}\text {-Services } \\
\text { - Credit to industrial and services sectors }\end{array}$ & 38.2 & 38.4 & 38.7 & 38.6 \\
\hline & & - FDI (Rs. million) & 1,210 & 1,794 & 2,765 & 880 \\
\hline & & - Additional employment & 3,731 & 3,572 & 2,194 & 5,660 \\
\hline & $\begin{array}{l}\text { Additional } \\
\text { employment in }\end{array}$ & $\begin{array}{l}\text { - N umber of training course an trainees } \\
\text { - N umber of industries registered }\end{array}$ & $-14,272$ & $139 / 13,615$ & $118 / 13,259$ & $566 / 9,132$ \\
\hline & SMES & - Total & 9,890 & 5,225 & 6,035 & 8146 \\
\hline & & - Cottage & & & 5,958 & \\
\hline
\end{tabular}


Cont'd...

\begin{tabular}{|c|c|c|c|c|c|c|}
\hline & Trade promotion & $\begin{array}{l}\text { - M edium \& Large } \\
\text { - Additional employment generated } \\
\text { - Average Tariff rates (\%) } \\
\text { - N umber of trade and industrial fairs }\end{array}$ & $\begin{array}{r}12.9 \\
11\end{array}$ & $\begin{array}{r}109 \\
- \\
11.5 \\
7\end{array}$ & $\begin{array}{r}77 \\
- \\
10.7 \\
16\end{array}$ & $\begin{array}{r}43 \\
83176 \\
9.6 \\
27\end{array}$ \\
\hline Labour & Remittances & $\begin{array}{l}\text { - N umber of N epali workers } \\
\text { employed overseas } \\
\text { - Proportion of skilled migrant workers }\end{array}$ & 104,739 & 105,055 & 106,000 & 139,696 \\
\hline Tourism & $\begin{array}{l}\text { Tourism contri } \\
\text { contribution }\end{array}$ & $\begin{array}{l}\text { - N umber of tourist arrivals } \\
\text {-total } \\
\text {-by air } \\
\text {-by road } \\
\text { - N umber of promotional activities } \\
\text { outsideN epal } \\
\text { - N umber of seats availableon } \\
\text { international flights (per week) } \\
\text { - Length of stay of tourists (days) } \\
\text { - N umber of flights outside } \\
\text { K athmandu (per weak) } \\
\text { - N umber of beds available outside } \\
\text { K athmandu } \\
\text { - N umber of star hotels } \\
\text { - Foreign exchangeearningfrom tourism } \\
\text { (Rs Million) } \\
\text { - Share of tourism in GDP }\end{array}$ & $\begin{array}{r}275,468 \\
218,660 \\
56,808 \\
19 \\
42,000 \\
12\end{array}$ & $\begin{array}{r}338,132 \\
275,438 \\
62,694 \\
22 \\
46,000 \\
7.9 \\
70 \\
14,795 \\
108 \\
10,369 \\
2.6\end{array}$ & $\begin{array}{r}385,297 \\
297,335 \\
87,962 \\
\\
30 \\
\\
50,000 \\
9.5 \\
118 \\
15,192 \\
108\end{array}$ & $\begin{array}{r}\text { NA } \\
131,210 \\
\text { NA } \\
33 \\
50,214 \\
13.5 \\
113 \\
39,384 \\
110 \\
13,140 \\
\text { NA }\end{array}$ \\
\hline Roads & $\begin{array}{l}\text { Increased road } \\
\text { access } \\
\text { Reduced transport } \\
\text { costs }\end{array}$ & $\begin{array}{l}\text { - N umber of district } \mathrm{HQ} \text { s connected } \\
\text { - BOT projects (selected) } \\
\text { - Length of additional road constructed } \\
\text { (km) }\end{array}$ & 283 & $\begin{array}{r}61 \\
10 \\
306\end{array}$ & 234 & $295 \#$ \\
\hline $\begin{array}{l}\text { Environ- } \\
\text { ment }\end{array}$ & $\begin{array}{l}\text { Environment } \\
\text { Improvement }\end{array}$ & $\begin{array}{l}\text { - Proportion of traditional fuel in total } \\
\text { energy use } \\
\text { - Energy per capita use (Ton. of oil } \\
\text { equivalent) }\end{array}$ & 87.4 & 87.4 & 86.8 & \\
\hline $\begin{array}{l}\text { Decentrali- } \\
\text { sation }\end{array}$ & $\begin{array}{l}\text { Improved service } \\
\text { delivery }\end{array}$ & $\begin{array}{l}\text { - N umber of service delivery facilities } \\
\text { transferred to local bodies } \\
\text { - Agriculture extension (Districts) } \\
\text { - H ealth facilities } \\
\text { - Rural roads (km) } \\
\text { - Primary and secondary } \\
\text { - N umber of local body officials trained } \\
\text { - N umber of districts completing and } \\
\text { updating DPPs } \\
\text { - N umber of districts (DDC) with } \\
\text { Citizen Charters } \\
\text { - Proportion of conditional grant in } \\
\text { toal development buddet (\%) }\end{array}$ & NS & $\begin{array}{r}75 \\
468 \\
- \\
90 \\
-\end{array}$ & $\begin{array}{r}75 \\
1,114 \\
- \\
1,500 \\
578 \\
52 \\
54\end{array}$ & $\begin{array}{r}75 \\
1,303 \\
1,2000 \\
2,091 \\
2,091 \\
\\
52 \\
75\end{array}$ \\
\hline $\begin{array}{l}\text { Information } \\
\text { and comm } \\
\text { unication }\end{array}$ & $\begin{array}{l}\text { Telephone } \\
\text { penetration per } \\
\text { thousand } \\
\text { inhabitants } \\
\text { A ccess to radio/ }\end{array}$ & $\begin{array}{l}\text { - Private sector entry } \\
\text { - N umber of telephonelines } \\
\text { - Number of VDCs with telephone } \\
\text { facility } \\
\text { - Coverage (\% of population) radio }\end{array}$ & $\begin{array}{r}219,000 \\
1,761\end{array}$ & $\begin{array}{r}1 \\
422,183 \\
1,761\end{array}$ & $\begin{array}{r}2 \\
608,084 \\
1,959\end{array}$ & $\begin{array}{r}3 \\
712,333 \\
2245\end{array}$ \\
\hline
\end{tabular}

* indudingnon-sar, \#induding $197 \mathrm{~km}$ of rehabilitation rœad 
Cont'd...

\begin{tabular}{|c|c|c|c|c|c|c|}
\hline \multirow{5}{*}{ Education } & TV services & $\begin{array}{l}\text { and television services } \\
\text { - Number of new television and radio } \\
\text { providers (to increase intensity) } \\
\text { - Radio } \\
\text { - Television }\end{array}$ & $90 / 50$ & $90 / 60$ & $100 / 62$ & $100 / 65$ \\
\hline & Improved access & \begin{tabular}{|l|} 
- N umber of primary schools \\
- Net primary enrolment rate \\
- Proportion of population more than \\
$1 / 2$ hourswalk to primary schools
\end{tabular} & $\begin{array}{r}25,194 \\
81.1\end{array}$ & $\begin{array}{r}26,638 \\
82.4\end{array}$ & $\begin{array}{r}26,858 \\
84 \\
91.4\end{array}$ & $\begin{array}{r}26,277 \\
87 \\
91.4\end{array}$ \\
\hline & $\begin{array}{l}\text { Quality of } \\
\text { education }\end{array}$ & $\begin{array}{l}\text { - N umber of certified teachers } \\
\text { - Percentage of pupil completing } \\
\text { primary leve } \\
\text { - Share of age } 5 \text { children in school } \\
\text { - Primary teacherstrained (\%) } \\
\text { - Secondary teachers trained (\%) } \\
\text { - Proportion of vacant teachers positions } \\
\text { - N umber of schoolstranfer red to } \\
\text { communities } \\
\text { - Primary cycle completion }\end{array}$ & \begin{tabular}{r|}
60 \\
- \\
15 \\
NA
\end{tabular} & \begin{tabular}{r|}
27,875 \\
67.7 \\
- \\
15 \\
46.2 \\
$N A$
\end{tabular} & \begin{tabular}{r|}
120,988 \\
69 \\
- \\
31 \\
48 \\
$\mathrm{NV}$ \\
\\
1500 \\
50.4
\end{tabular} & $\begin{array}{r}\text { NA } \\
\\
78 \\
\text { NA } \\
35 \\
50 \\
\text { NV } \\
\\
2091 \\
68\end{array}$ \\
\hline & $\begin{array}{l}\text { Adult literacy } \\
(15+1)\end{array}$ & $\begin{array}{l}\text { - N umber of community learning centres } \\
\text { - A dult literacy rate } \\
\text { - Share of adult education expenditure } \\
\text { in total education expediture \% }\end{array}$ & $\begin{array}{r}20 \\
44 \\
0.9\end{array}$ & $\begin{array}{r}40 \\
- \\
0.5\end{array}$ & $\begin{array}{l}52 \\
48\end{array}$ & $\begin{array}{l}51 \\
48\end{array}$ \\
\hline & $\begin{array}{l}\text { Female adult } \\
\text { literacy }(15+1)\end{array}$ & $\begin{array}{l}\text { - N umber of programmes for women } \\
\text { literacy (class) } \\
\text { - A dult female literacy rate } \\
\text { - N umber of people completing adult } \\
\text { education }\end{array}$ & 23,942 & 26,733 & $\begin{array}{r}1,745 \\
33.8 \\
39,262\end{array}$ & $\begin{array}{r}38,974 \\
33.8 \\
183,000\end{array}$ \\
\hline \multirow{5}{*}{ H ealth } & Girls enrolment & $\begin{array}{l}\text { - Share of female teachersin primary } \\
\text { schools (\%) } \\
\text { - Number of girl students receiving } \\
\text { scholarships (pl) } \\
\text { - Schools with separatelatrines for girls }\end{array}$ & $\begin{array}{r}21.4 \\
151,568 \\
7,613\end{array}$ & $\begin{array}{r}22.1 \\
120,742 \\
9,741\end{array}$ & $\begin{array}{r}21.1 \\
224,656 \\
10,633\end{array}$ & $\begin{array}{r}30 \\
635,380 \\
11341\end{array}$ \\
\hline & A ccess to health & $\begin{array}{l}\text { - N umber of primary health centers, } \\
\text { health posts, sub-health post and } \\
\text { district hospitals } \\
\text { - N umber of sub-health posts transferred } \\
\text { - Proportion of population within } 30 \\
\text { minutes walk to health facilities } \\
\text { outreach clinics }\end{array}$ & 4,429 & $\begin{array}{r}4,408 \\
468\end{array}$ & $\begin{array}{l}4,401 \\
1,114\end{array}$ & $\begin{array}{l}4,401 \\
1,303\end{array}$ \\
\hline & Improved quality & $\begin{array}{l}\text { - Expenditure on medicine for health } \\
\text { centres (Rs.) } \\
\text { - N umber of health facilities where } 15 \text { of } \\
\text { the most essential drugs are available }\end{array}$ & 80,000 & $\begin{array}{r}80,000 \\
1568\end{array}$ & 80,000 & $\begin{array}{r}75,000 \\
4012\end{array}$ \\
\hline & $\begin{array}{l}\text { Infant mortality } \\
\text { rate }\end{array}$ & $\begin{array}{l}\text { - Percentage of women receiving at } \\
\text { least } 4 \text { AN C visits } \\
\text { - Percentage of women receiving } \\
\text { adequate PN C (post natal care) visits } \\
\text { - Infant mortality rate (per thousand } \\
\text { live births) }\end{array}$ & $\begin{array}{r}14.4 \\
64\end{array}$ & $\begin{array}{c}36.8 \\
18.8\end{array}$ & 28.3 & $\begin{array}{l}44.1 \\
30.4\end{array}$ \\
\hline & Child mortality rate & - Percentage of oneyear olds receiving & & & & \\
\hline
\end{tabular}

$N V=N$ ot Vacant 


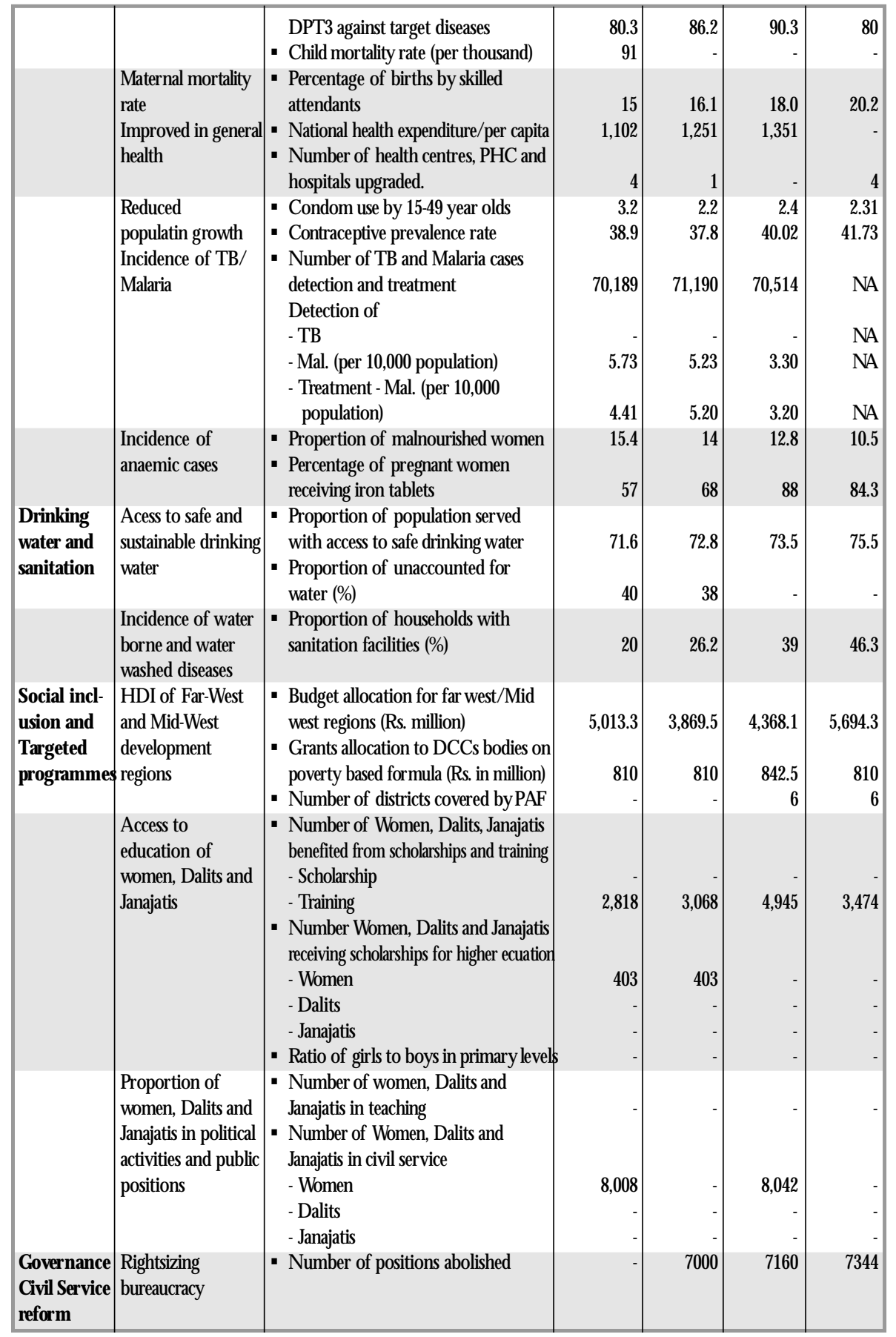


Cont'd...

\begin{tabular}{|l|l|l|r|r|r|r|}
\hline & $\begin{array}{l}\text { Percentage of } \\
\text { women, ethnic and }\end{array}$ & - N umber of applications from women, & & & & \\
& disadvantaged & - Women & & & & \\
& groups in civil & - Dalits & 21,247 & 25,174 & 16,014 & 22,310 \\
& services & - Janjatis & 135 & 1,028 & 810 & 991 \\
Anti- & & 3,199 & 29,030 & 21,423 & 20,289 \\
corruption & Corruption cases & - N umber of corruption cases: & & & & \\
& reduced & - Registered/ filed & 61 & 147 & 98 & 113 \\
& & - Adjusted & - & 55 & 129 & 106 \\
& & - Convicted (fully) & - & 47 & 120 & 97 \\
Human & Reduced human & - N umber of human rights complaints & & & & \\
rights & rights violations & filed/ registered & - & 483 & 1,083 & 1,782 \\
\hline
\end{tabular}


